\title{
EFEITO DA AÇÃO ALCALINIZANTE E DA COMPETIÇÃO ENTRE SILICATO E FOSFATO NA EFICIÊNCIA DO TERMOFOSFATO MAGNESIANO EM SOLOS ÁCIDOS
}

\section{JOSÉ RAFAEL MÉNDEZ BALDEÓN \\ Engenheiro Agrônomo}

Orientador: Prof. Dr. JORGE DE CASTRO KIEHL

Tese apresentada à Escola Superior de Agricultura "Luiz de Queiroz", da Universidade de São Paulo, para obtenção do título de Doutor em Agronomia, Área de Concentração: Solos e Nutrição de Plantas.

P I R A C I C A B A

Estado de São Paulo - Brasil

Janeiro - 1995 
Ficha catalográfica preparada pela Seção de Livuros da Divisẩo de Biblioteca e Documentação - PCLQ/USP

Méndez Baldeón, José Rafael

M538e Efeito da ação alcalinizante e da competição entre silicato e fosfato na eficiência do termofosfato magnesiano em solos ácidos. Piracicaba, 1995.

$88 p$. ilus.

Tese - ESALQ

Bibliografia.

1. Fosfato em solo ácido 2. Silicato em solo ácido 3. Termofosfato em solo ácido I. Escola Superior de Agricultura Luiz de Queiroz, Piracicaba

CDD 631.42 


\section{EFEITO DA AÇÃO ALCALINIZANTE E DA COMPETIÇÃO ENTRE SILICATO E FOSFATO NA EFICIÊNCIA DO TERMOFOSFATO MAGNESIANO EM SOLOS ÁCIDOS}

JOSÉ RAFAEL MÉNDEZ BALDEÓN

Aprovada em 08.03.1995

Comissão Julgadora:

Prof. Dr. Jorge de Câstro Kiêht;

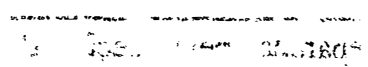

ESALQ/USP

Prof. Dr. Takashi Muraoka

CENA/USP

Prof. Dr. Antonio Enedi Boaretto

CENA/USP

Prof. Dr. Leonardo Teodoro Bull

UNESP/Botucatu

Prof. Dr. Iraê Amaral Guerrini

UNESP/Botucatu

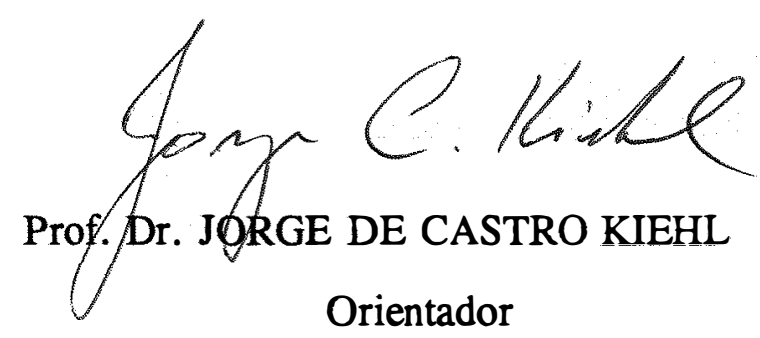


Aos meus queridos pais:

José Rafael e Zoila Rosa

e aos meus irmãos:

Jhon, José Eduardo, José Francisco,

Guillermo, Zoila e Consuelito,

\section{OFEREÇO}

À minha amada esposa e companheira, Maria dos Anjos, pelo apoio e compreensão, e à minha querida filha, Melissa Katherine, que o SENHOR as proteja, 


\section{AGRADECIMENTOS}

\section{AGRADEÇO}

A DEUS, pela saúde e inteligência, e pelas vicissitudes boas e ruins que me aconteceram durante o período de realização deste curso, as quais só me fizeram entender o "dia-a-dia" e crescer profissional e espiritualmente.

Ao Professor, Dr. Jorge de Castro Kiehl, pela segura orientação, paciência, dedicação e sugestões para o bom desenvolvimento deste trabalho e, acima de tudo, pela amizade e confiança com que sempre me distinguiu.

À Escola Superior de Agricultura "Luiz de Queiroz" (ESALQ/USP) pela oportunidade proporcionada para a realização do Curso de Doutorado e aos professores do Departamento de Ciência do Solo, pelos ensinamentos.

À CAPES (Coordenação de Aperfeiçoamento de Pessoal de Nível Superior), pelo precioso auxílio financeiro concedido através de bolsa de estudos.

Ao Dr. Bernardo van Raij, Pesquisador Científico do Instituto Agronômico de Campinas (IAC), pela especial atenção e valiosas sugestões.

Ao Professor, Dr. Eurípedes Malavolta, Pesquisador do Centro de Energia Nuclear na Agricultura (CENA), Seção de Nutrição Mineral de Plantas, pelas sugestões e apoio fundamental e inestimável, permitindo o uso das instalações de laboratório.

Ao Professor, Dr. Takashi Muraoka, Pesquisador do Centro de Energia Nuclear na Agricultura (CENA), pela ajuda na complementação das análises de solos, e especialmente pela amizade, valiosos conselhos e sugestões. 
À Fertilizantes Mitsui S.A. Ind. e Com., pelo apoio financeiro recebido, para a realização da presente pesquisa.

Ao colega e amigo Eng ${ }^{\circ}$ Agr $^{\circ}$ M.Sc. Minori Yasuda, Sub-Gerente do Departamento de Fertilizantes da Mitsui, pelo incentivo e sugestões.

À Universidade do Tocantins (UNITINS), pela concessão do afastamento e incentivo, para concluir a etapa final do Curso de Doutorado.

Ao Dr. Roberto Antonio Arévalo, pela amizade e apoio moral durante o Curso.

À Clotilde Maria Batochio Cunha, Secretária da Revista Scientia Agricola, pela gentileza e boa vontade dispensada em todo momento, pelo trabalho e organização da datilografia e sobretudo, pela amizade oferecida.

À Marileuza Aparecida Bassi Elias e Sandra Teresa Pereira dos Santos, técnicas de laboratório da Seção de Fertilidade do Solo/CENA, pela colaboração dispensada durante a realização das análises de solo

À Bióloga, Cleusa Pereira Cabral, técnica de laboratório da Seção de Nutrição Mineral de Plantas/CENA, pela gentileza e valiosa colaboração brindada durante a realização das análises de solo e planta e, acima de tudo, pela amizade.

À Katia Maria de Andrade Ferraz, Bibliotecária da ESALQ/USP, pela gentileza dispensada em todos os momentos.

À todos que, de uma forma ou de outra, contribuiram para este trabalho.

Finalmente, à minha amada esposa Maria dos Anjos, pelo carinho, incentivo, paciência e compreensão, e à minha querida Mãe Zoila Rosa Baldeón de Mendez, por toda sua ternura, carinho, sacrifício e apoio, durante minha existência. 
SUMÁRIO

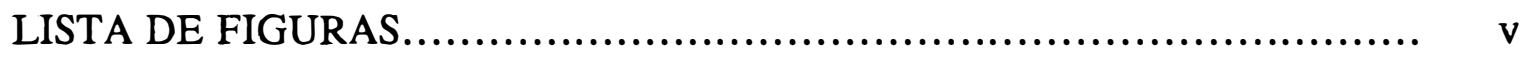

LISTA DE TABELAS........................................................ vii

RESUMO ................................................................. xii

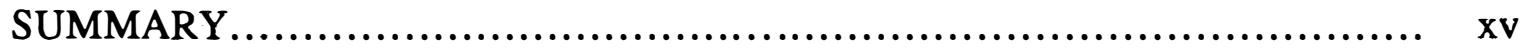

1. INTRODUÇÃO .............................................................. 1

2. REVISÃO DE LITERATURA......................................... 3

2.1. O fósforo no solo.................................................. 3

2.2. O silício no solo e na planta............................................. 4

2.3. Interação entre silício e fósforo......................................... 9

2.4. Termofosfato magnesiano e seu uso................................... 13

3. MATERIAL E MÉTODOS.................................................. 16

3.1. Localização, amostragem e caracterização dos solos..................... 16

3.2. Caracterização das fontes de fósforo e do corretivo de acidez............ 19

3.3. Obtenção da curva de neutralização........................................ 19

3.4. Instalação e condução do experimento.................................. 20

3.5. Análise química das amostras de solo................................. 21

3.5.1. $\mathrm{pH}$, cátions trocáveis e acidez potencial......................... 21

3.5.2. Fósforo extraído pelo método da resina.......................... 21

3.5.3. Fósforo extraído pelo método de Bray-1....................... 22

3.5.4. Sílica solúvel.................................................... 22

3.6. Análise do material vegetal.......................................... 22

3.6.1. Teor de fósforo............................................. 22

3.6.2. Teor de silício................................................. 22

3.7. Parâmetros avaliados e análises estatísticas............................. 23 
4. RESULTADOS E DISCUSSÃO........................................ 24

4.1. Parâmetros do solo.................................................. 24

4.1.1. $\mathrm{pH}$ em $\mathrm{CaCl}_{2}$ e Saturação por Bases........................... 24

4.1.2. Fósforo Extraído pelo Método da Resina........................ 33

4.1.3. Fósforo Extraído pelo Método de Bray-1....................... 37

4.1.4. Sílica solúvel................................................... 42

4.2. Parâmetros da planta............................................ 48

4.2.1. Produção de matéria seca da parte aérea.......................... 48

4.2.2. Toor de silício na parte aérea................................ 52

4.2.3. Quantidade de silício acumulada na parte aérea.................. 57

4.2.4. Teor de fósforo na parte aérea.................................. 60

4.2.5. Quantidade de fósforo acumulada na parte aérea................. 63

4.2.6. Correlações entre variáveis........................................ 69

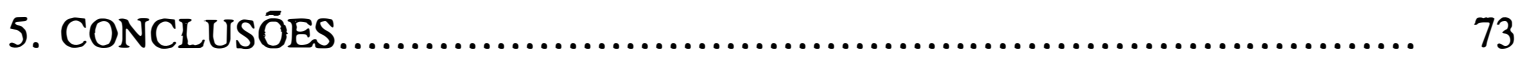

REFERÊNCIAS BIBLIOGRÁFICAS................................ 75

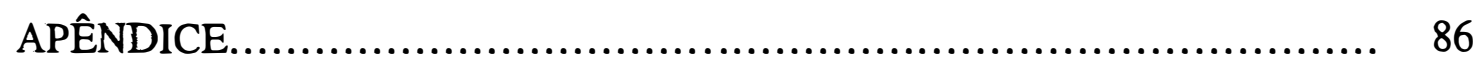




\section{LISTA DE FIGURAS}

1 - Valores de $\mathrm{pH}$ em $\mathrm{CaCl}_{2}$ (a) de amostras de solo tratadas com termofosfato magnesiano (TM), superfosfato triplo + calcário (ST $+\mathrm{CAL}$ ) e superfosfato triplo (ST) em diferentes doses de fósforo (médias de dois solos) e (b) de amostras de Terra Roxa Estruturada (TE) e Latossolo Roxo (LR), tratadas com diferentes doses de fósforo (médias de três fontes de fósforo)

2 - Porcentagem de saturação por bases (V\%), de amostras de Terra Roxa Estruturada (TE) e Latossolo Roxo (LR) tratadas com termofosfato magnesiano (TM), superfosfato triplo + calcário (ST $+\mathrm{CAL}$ ) e superfosfato triplo (ST) em diferentes doses de fósforo

3 - Teores de fósforo extraídos pela resina (a) de amostras de solotratadas com termofosfato magnesiano (TM), superfosfato triplo + calcário (ST + CAL) e superfosfato triplo (ST) em diferentes doses de fósforo (médias de dois solos) e (b) de amostras de Terra Roxa Estruturada (TE) e Latossolo Roxo (LR), tratadas com diferentes doses de fósforo (médias de três fontes de fósforo)

4 - Teores de fósforos extraídos pelo método Bray-1, de amostras deTerra Roxa Estruturada (TE) e Latossolo Roxo (LR), tratadas com termofosfato magnesiano (TM), superfosfato triplo + calcário(S + CAL) Te superfosfato triplo (ST) em diferentes doses de fósforo

5 - Teores de sílica solúvel, de amostras de Terra Roxa Estruturada (TE) e Latossolo Roxo (LR), tratadas com termofosfato magnesiano (TM), superfosfato triplo + calcário (ST $+\mathrm{CAL}$ ) e superfosfato triplo (ST) em diferentes doses de fósforo 
6 - Curvas de resposta da produção de matéria seca da parte aérea de plantas de arroz, para amostras de Terra Roxa Estruturada (TE) e Latossolo Roxo (LR) tratadas com termofosfato magnesiano (TM), superfosfato triplo + clcário $(\mathrm{ST}+\mathrm{CAL})$ e superfosfato triplo (ST) em diferentes doses de fósforo

7 - Teores de silício na parte aérea das plantas de arroz (a) de amostras de solo tratadas com termofosfato magnesiano (TM), superfosfato triplo + calcário (ST + $\mathrm{CAL}$ ) e superfosfato triplo (ST) em diferentes doses de fósforo (médias de dois solos) e (b) de amostras Terra Roxa Estruturada (TE) e Latossolo Roxo (LR), tratadas com diferentes doses de fósforo (médias de três fontes de fósforo)

8 - Curvas de resposta do silício acumulado na parte aérea de plantas de arroz (a) de amostras de solo tratadas com termofosfato magnesiano (TM), superfosfato triplo + calcário (ST + CAL) e superfosfato triplo (ST) em diferentes doses de fósforo (médias de dois solos) e (b) de amostras de Terra Roxa Estruturada (TE) e Latossolo Roxo (LR), tratadas com diferentes doses de fósforo (médias de três fontes de fósforo)

9 - Teores de fósforo na parte aérea das plantas de arroz (a) de amostras de solo tratadas com termofosfato magnesiano (TM), superfosfato triplo + calcário (ST + $\mathrm{CAL}$ ) e superfosfato triplo (ST) em diferentes doses de fósforo (médias de dois solos) e (b) de amostras Terra Roxa Estruturada (TE) e Latossolo Roxo (LR), tratadas com diferentes doses de fósforo (médias de três fontes de fósforo)

10 - Curvas de resposta ao fósforo acumulado na parte aérea de plantas de arroz para amostras de Terra Roxa Estruturada (TE) e Latossolo Roxo (LR), tratadas com termofosfato magnesiano (TM), superfosfato triplo + calcário $(\mathrm{ST}+\mathrm{CAL})$ e superfosfato triplo (ST) em diferentes doses de fósforo 


\section{LISTA DE TABELAS}

1 - Características físicas das amostras dos solos utilizadas no experimento

2 - Características químicas das amostras dos solos utilizadas no experimento

3 - Valores de $\mathrm{F}$ e coeficientes de variação (CV) para valores de $\mathrm{pH}$ em $\mathrm{CaCl}_{2}$, saturação por bases $(\mathrm{V})$, teores de $\mathrm{P}$ extraídos pelos métodos da resina e Bray-1 e teores de sílica solúvel, de amostras de dois solos tratadas com diferentes fontes e doses de fósforo

4 - Valores de $\mathrm{pH}$ em $\mathrm{CaCl}_{2}$ de amostras de Terra Roxa Estruturada (TE) e Latossolo Roxo (LR) tratadas com diferentes doses de fósforo (média de quatro repetições e de três fontes fosfatadas: termofosfato magnesiano, superfosfato triplo + calcário e superfosfato riplo)

5 - Valores $\mathrm{pH}$ em $\mathrm{CaCl}_{2}$ de amostras de solo tratadas com diferentes doses e fontes de fósforo (médias de quatro repetições e de dois solos, Terra Roxa Estruturada e Latossolo Roxo)

6 - Valores de $\mathrm{pH}$ em $\mathrm{CaCl}_{2}$ de amostras de Terra Roxa Estruturada (TE) e Latossolo Roxo (LR) tratadas com diferentes fontes de fósforo (média de quatro repetições e de quatro doses de fósforo: $0,50,100$ e $200 \mathrm{mg} / \mathrm{kg}$ de P) 
7 - Saturação por bases (V) de amostras de Terra Roxa Estruturada (TE) e Latossolo Roxo (LR) tratadas com diferentes doses de fósforo, para cada fonte fosfatada (média de quatro repetições)

30

8 - Saturação por bases $(V)$ de amostras de terra tratadas com diferentes doses e fontes de fósforo, para cada solo (Terra Roxa Estruturada, TE; e Latossolo Roxo, LR (média de quatro repetiçōes)

9 - Teores de fósforo extraído pelo método da resina, de amostras de Terra Roxa Estruturada (TE) e Latossolo Roxo (LR) tratadas com diferentes doses de fósforo (média de quatro repetições e de três fontes fosfatadas: termofosfato magnesiano, superfosfato triplo + calcário e superfosfato triplo)

10 - Teores de fósforo extraído pelo método da resina, de amostras de solo tratadas com diferentes doses e fontes de fósforo (médias de quatro repetições e de dois solos, Terra Roxa Estruturada e Latossolo Roxo)

11 - Teores de fósforo extraído pelo método de Bray-1, de amostras de Terra Roxa Estruturada (TE) e Latossolo Roxo (LR) tratadas com diferentes doses de fósforo, para cada fonte fosfatada (média de quatro repetiçōes)

12 - Teores de fósforo extraído pelo método de Bray-1, de amostras de terra tratadas com diferentes doses e fontes de fósforo, para cada solo (Terra Roxa Estruturada, TE; e Latossolo Roxo, LR) (média de quatro repetições)

13 - Teores de sílica solúvel de amostras de Terra Roxa Estruturada (TE) e Latossolo Roxo (LR) tratadas com diferentes doses de fósforo, para cada fonte fosfatada (média de quatro repetições) 
14 - Teores de sílica solúvel de amostras de Terra Roxa Estruturada (TE) e Latossolo Roxo (LR) tratadas com diferentes doses e fontes de fósforo (média de quatro repetições)

15 - Valores de $\mathrm{F}$ e coeficientes de variação (C.V.) para produção de matéria seca e teores e quantidades acumuladas de silício e fósforo na parte aérea de plantas de arroz cultivadas em amostras de dois solos tratadas com diferentes fontes e doses de fósforo

16 - Produção de matéria seca pela parte aérea de plantas de arroz cultivadas em amostras de Terra Roxa Estruturada (TE) e Latossolo Roxo (LR) tratadas com diferentes doses de fósforo, para cada fonte fosfatada (média de quatro repetições)

17 - Produção de matéria seca pela parte aérea de plantas de arroz cultivadas em amostras de terra tratadas com diferentes doses e fontes de fósforo, para cada solo (Terra Roxa Estruturada, TE; e Latossolo Roxo, LR) (média de quatro repetições)

18 - Teores de silício na parte aérea de plantas de arroz cultivadas em amostras de Terra Roxa Estruturada (TE) e Latossolo Roxo (LR) tratadas com diferentes doses de fósforo (média de quatro repetições e de três fontes fosfatadas: termofosfato magnesiano, superfosfato triplo + calcário e superfosfato triplo)

19 - Teores de silício na parte aérea de plantas de arroz cultivadas em amostras de solo tratadas com diferentes doses e fontes de fósforo (médias de quatro repetições e de dois solos, Terra Roxa Estruturada e Latossolo Roxo) 
20 - Teores de silício na parte aérea de plantas de arroz cultivadas em amostras de Terra Roxa Estruturada (TE) e Latossolo Roxo (LR) tratadas com diferentes fontes de fósforo (média de quatro repetições e de quatro doses de fósforo: $0,50,100 \mathrm{e}$ $200 \mathrm{mg} / \mathrm{kg}$ de P)

21 - Quantidades de silício acumuladas na parte aérea de plantas de arroz cultivadas em amostras de Terra Roxa Estruturada (TE) e Latossolo Roxo (LR) tratadas com diferentes doses de fósforo (média de quatro repetições e de três fontes fosfatadas: termofosfato magnesiano, superfosfato triplo + calcário e superfosfato triplo)

22 - Quantidades de silício acumuladas na parte aérea de plantas de arroz cultivadas em amostras de solo tratadas com diferentes doses e fontes de fósforo (médias de quatro repetições e de dois solos, Terra Roxa Estruturada e Latossolo Roxo)

23 - Teores de fósforo na parte aérea de plantas de arroz cultivadas em amostras de Terra Roxa Estruturada (TE) e Latossolo Roxo (LR) tratadas com diferentes doses de fósforo (média de quatro repetições e de três fontes fosfatadas: termofosfato magnesiano, superfosfato triplo + calcário e superfosfato triplo)

24 - Teores de fósforo na parte aérea de plantas de arroz cultivadas em amostras de solo tratadas com diferentes doses e fontes de fósforo (médias de quatro repetições e de dois solos, Terra Roxa Estruturada e Latossolo Roxo)

61

25 - Quantidades de fósforo acumuladas na parte aérea de plantas de arroz cultivadas em amostras de Terra Roxa Estruturada (TE) e Latossolo Roxo (LR) tratadas com diferentes doses de fósforo, para cada fonte fosfatada (média de quatro repetições) 
26 - Quantidades de fósforo acumuladas na parte aérea de plantas de arroz cultivadas em amostras de terra tratadas com diferentes doses e fontes de fósforo, para cada solo (Terra Roxa Estruturada, TE; e Latossolo Roxo, LR) (média de quatro repetições)

27 - Relações entre as quantidades de silício e fósforo acumuladas na parte aérea de plantas de arroz cultivadas em amostras de Terra Roxa Estruturada (TE) e Latossolo Roxo (LR) tratadas com diferentes doses e fontes de fósforo

28 - Coeficientes de correlação linear entre algumas variáveis relacionadas à parte aérea de plantas de arroz cultivadas em amostras de Terra Roxa Estruturada (TE) e Latossolo Roxo (LR) tratadas com diferentes doses de fósforo; número de observações igual a 12 (4 repetições $\times 3$ fontes)

29 - Coeficientes de correlação linear entre algumas variáveis relacionadas à parte aérea de plantas de arroz cultivadas em amostras de Terra Roxa Estruturada (TE) e Latossolo Roxo (LR) tratadas com diferentes fontes de fósforo; número de observações igual a 16 (4 repetições $x 4$ doses) 


\title{
EFEITO DA AÇÃO ALCALINIZANTE E DA COMPETIÇĀO \\ ENTRE SILICATO E FOSFATO NA EFICIÊNCIA DO \\ TERMOFOSFATO MAGNESIANO EM SOLOS ÁCIDOS
}

\author{
Autor: JOSÉ RAFAEL MÉNDEZ BALDEÓN \\ Orientador: Prof. Dr. Jorge de Castro Kiehl
}

\section{RESUMO}

Este experimento foi conduzido em casa-de-vegetação sob delineamento inteiramente casualizado com quatro repetiçōes e tratamentos em arranjo fatorial $3 \times 4 \times$ 2, com a finalidade de avaliar se o efeito favorável do termofosfato magnesiano sobre a absorção de fósforo e produção de matéria seca pelas plantas deve-se (a) à menor "fixação" do fósforo causada pela elevação do $\mathrm{pH}$, já que o termofosfato é um fertilizante alcalino; ou (b) à competição entre o silicato contido no termofosfato e o fosfato, pelos mesmos sítios de adsorção no solo; ou (c) a ambos esses efeitos. Os fatores foram constituídos de três fontes de fósforo (termofosfato magnesiano; superfosfato triplo; e superfosfato triplo mais corretivo de acidez), quatro doses de fósforo $(0,50,100$ e $200 \mathrm{mg} / \mathrm{kg}$ de P) e dois solos ácidos, Terra Roxa Estruturada, TE e Latossolo Roxo, LR, situados nos municípios de Piracicaba (SP) e Jardinópolis (SP). O termofosfato magnesiano, denominado comercialmente "MG-YOORIN", apresentou $17,30 \%$ de $\mathrm{P}_{2} \mathrm{O}_{5}$ solúveis em ácido cítrico a

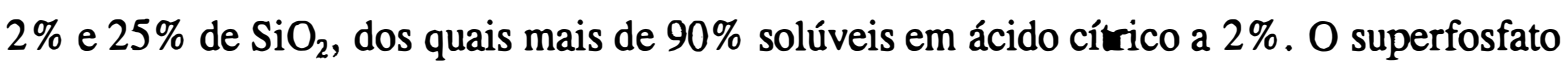
triplo continha $44,98 \%$ de $\mathrm{P}_{2} \mathrm{O}_{5}$ solúveis em solução neutra de citrato de amônio + água. 
O corretivo de acidez constituiu-se de uma mistura de carbonato de cálcio e carbonato de magnésio na proporção de 4:1 em equivalentes; as quantidades do corretivo foram calculadas através de curvas de neutralização para equivalerem ao poder neuralizante das diferentes doses de termofosfato magnesiano. Todos esses materiais foram aplicados na forma de pó.

Amostras de $5,5 \mathrm{~kg}$ de terra da camada $0-20 \mathrm{~cm}$ de cada solo foram intimamente misturadas com as fontes de fósforo, umedecidas a $70 \%$ da capacidade de retenção de água e incubadas em vasos por 20 dias. Após esse período, subamostras de 0,5 $\mathrm{kg}$ foram retiradas para determinações do $\mathrm{pH}$ em $\mathrm{CaCl}_{2} 0,01 \mathrm{M}$, cátions trocáveis, acidez potencial, P-resina, P-Bray I e sílica solúvel. Uma adubação básica foi realizada com N, $\mathrm{K}, \mathrm{B}, \mathrm{Cu}, \mathrm{Mo}, \mathrm{Mn}, \mathrm{Zn}$ e Fe. Nos tratamentos sem termofosfato e sem corretivo, cálcio e magnésio foram aplicados na forma de solução dos respectivos cloretos e nas mesmas quantidades aplicadas como corretivo. Após retornar as terras nos vasos e umedecê-las a $70 \%$ da capacidade máxima de retenção de água, oito plantas de arroz (Oriza sativa $\mathrm{L}$.), cultivar IAC 165, foram cultivadas em cada vaso por 75 dias. Em seguida, a parte aérea das plantas foi colhida, secada a $65^{\circ} \mathrm{C}$, pesada, moída e submetida à determinação dos teores de silício e fósforo.

O método de extração de fósforo pela resina mostrou-se superior ao do Bray-1 em avaliar o efeito das fontes sobre o teor de fósforo no solo, o qual se refletiu inclusive na produção de matéria seca e na quantidade de fósforo acumulada na parte aérea das plantas. $\mathrm{O}$ termofosfato magnesiano elevou o teor de P-resina em maior grau que o superfosfato triplo, causando ainda aumentos do $\mathrm{pH}$, da saturação por bases e do teor de sílica solúvel do solo. A aplicação de fósforo, devido ao efeito de diluição, reduziu acentuadamente o teor de silício da planta, mesmo quando a fonte era o termofosfato magnesiano; a aplicação de silício, contudo, não reduziu os teores de fósforo; esses fatos indicam que o $\mathrm{P}$ provavelmente tenha inibido a absorção de $\mathrm{Si}$, mas que o $\mathrm{Si}$ não tenha inibido a de $\mathrm{P}$. Todas as fontes de fósforo aumentaram a quantidade de silício acumulada na planta, porém, o termofosfato magnesiano destacou-se das demais. $\mathrm{O}$ termofosfato 
magnesiano e o superfosfato triplo associado ao corretivo do solo aumentaram igualmente a produção de matéria seca (nas doses 100 e $200 \mathrm{mg} / \mathrm{kg}$ de P para o solo TE e 50, 100 e $200 \mathrm{mg} / \mathrm{kg}$ de P para o LR) e a quantidade de fósforo acumulada na planta (nas doses 100 e $200 \mathrm{mg} / \mathrm{kg}$ de $\mathrm{P}$ para o TE e 50 e $100 \mathrm{mg} / \mathrm{kg}$ de $\mathrm{P}$ para o LR), sendo esses aumentos superiores aos obtidos com o superfosfato triplo; assim, o efeito favorável do termofosfato magnesiano sobre o aproveitamento do fósforo e o desenvolvimento das plantas deve-se mais provavelmente à sua capacidade de elevar o $\mathrm{pH}$ do meio do que à influência benéfica da competição entre o silicato que contém e o fosfato, pelos mesmos sítios de adsorção no solo. O termofosfato magnesiano foi superior ao superfosfato triplo, com ou sem corretivo, quanto à produção de matéria seca e a quantidade de fósforo acumulada na planta quando aplicado na dose de $50 \mathrm{mg} / \mathrm{kg}$ de P na Terra Roxa Estruturada; esse comportamento devese, provavelmente, ao efeito combinado da sua ação alcalinizante com o da competição entre o silicato que contém e o fosfato. 


\title{
EFFECT OF THE ALKALINE ACTION AND THE COMPETITION BETWEEN SILICATE AND PHOSPHATE IN THE EFFICIENCY OF FUSED MAGNESIUM PHOSPHATE IN ACID SOILS
}

\author{
Author: JOSÉ RAFAEL MÉNDEZ BALDEÓN \\ Adviser: Prof. Dr. Jorge de Castro Kiehl
}

\section{SUMMARY}

A greenhouse experiment under a completely randomized design with four replicates was carried out in order to evaluate if the favorable effect of fused magnesium phosphate on the phosphorus absorption and yield of dry matter by plants is due to (a) a decrease in phosphorus "fixation" caused by the increase in $\mathrm{pH}$, since the fused magnesium phosphate is an alkaline fertilizer; or (b) a competition between the silicate anion present in the fused magnesium phosphate and the phosphate anion for the same adsorption sites in the soil; or (c) to both these effects. Treatments were under a $3 \times 4 \times 2$ factorial arrangement. The factors comprised three sources of phosphorus (fused magnesium phosphate; triple superphosphate; and triple superphosphate plus a lime material), four rates of phosphorus application (0, 50,100 e $200 \mathrm{mg} / \mathrm{kg}$ of P) and two soils, Terra Roxa Estruturada, TE (Alfisol) and Red Latosol, LR (Oxisol) both located in the State of São Paulo, Brazil. The fused magnesium phosphate, traded under the name of "MG-YOORIN", contained $17.30 \%$ of $\mathrm{P}_{2} \mathrm{O}_{5}$ soluble in $2 \%$ citric acid solution and $25 \%$ of $\mathrm{SiO}_{2}, 90 \%$ of which also soluble in $2 \%$ citric acid. The triple superphosphate showed a content of $44.98 \%$ of $\mathrm{P}_{2} \mathrm{O}_{5}$ soluble in neutral solution of ammonium citrate plus water. The lime 
material was obtained by mixing calcium and magnesium carbonates in a rate of $4: 1$ in equivalents; the application rates of lime were calculated by means of neutralization curves in order to obtain the same neutralizing capacity of the thermophosphate. All this materials were applied in the form of powder.

Surface $(0-20 \mathrm{~cm})$ samples of $5.5 \mathrm{~kg}$ of each soil were thoroughly mixed with the phosphorous materials, moistened to $70 \%$ of the water retention capacity and incubated in pots for 20 days. At the end of this period, subsamples of $0.5 \mathrm{~kg}$ were collected and subjected to determination of $\mathrm{pH}$ in $\mathrm{CaCl}_{2} 0,01 \mathrm{M}$, exchangeable cations, potential acidity, phosphorus extracted by resin and Bray-I methods, and soluble silica. All pots were fertilized with $\mathrm{N}, \mathrm{K}, \mathrm{B}, \mathrm{Cu}, \mathrm{Mo}, \mathrm{Mn}, \mathrm{Zn}$ and Fe. Pots not treated with thermophosphate or lime received calcium and magnesium in the form of a solution of the respective chlorides and in amounts equivalent to those applied as lime. After returning the soil samples to the pots and reweting to $70 \%$ of the water retention capacity, eight rice (Oriza sativa L.) plants, cultivar IAC 165, were grown in each pot for 75 days. Afterward, the plant tops were cropped, dried at $65^{\circ} \mathrm{C}$, weighted, grounded and subjected to determination of silicon and phosphorus content.

The resin method for the extraction of phosphorus was superior to the Bray-1 to evaluate the effect of the $P$ sources on the content of this element in the soil; this effect was reflected on the yield of dry matter by the plant and on the amount of phosphorus accumulated in the plant tops. Fused magnesium phosphate increased the soil resinextracted $\mathrm{P}$ to a higher level than the triple superphosphate; it also increased the $\mathrm{pH}$, the base saturation and the soluble silica content of the soil. Phosphorus application reduced markedly the silicon content of the plant due to the dilution effect, even when the thermophosphate was applied; however, silicon application did not reduce the phosphorus content; these facts sugest that phosphorus might have inhibited the absorption of silicon, but silicon did not inhibited that of phosphorus. All the sources of phosphorus increased the amount of silicon accumulated in the plant, but fused magnesium phosphate was superior to the others. This fertilizer and the triple superphosphate plus lime were equally 
effective in increasing the yield of dry matter (at the rates of 100 and $200 \mathrm{mg} / \mathrm{kg}$ of $P$ for the TE soil and 50, 100 and $200 \mathrm{mg} / \mathrm{kg}$ of $\mathrm{P}$ for the LR) and the amount of phosphorus accumulated by the plant (at the rates of 100 and $200 \mathrm{mg} / \mathrm{kg}$ of $P$ for the TE and of 50 and $100 \mathrm{mg} / \mathrm{kg}$ of $\mathrm{P}$ for the LR); because these raises were higher than those observed with the addition of triple superphosphate, the stimulating effect of fused magnesium phosphate on the absorption of phosphorus and plant development was more probably due to its capacity of increasing the soil $\mathrm{pH}$ than to the favorable influence of the competition between the silicate it bears and the phosphate, for the same adsorption sites of the soil. Fused magnesium phosphate was superior to both triple superphosphate with or without lime in respect to the yield of dry matter and to the amount of phosphorus accumulated in the plant when this fertilizer was applied in the rate of $50 \mathrm{mg} / \mathrm{kg}$ of $\mathrm{P}$ to the Terra Roxa Estruturada; this behavior is probably due to a combined effect of the alkaline action of this fertilizer with the competition effect between its silicate and phosphate anions. 


\section{INTRODUÇÃO}

Os solos de cerrado, assim como a maior parte dos solos ácidos de regiōes tropicais e subtropicais, são em geral extremamente pobres em fósforo disponível para as plantas. A correção da deficiência desse nutriente, por outro lado, exige a aplicação de grandes quantidades de fosfato devido à alta capacidade de fixação de fósforo desses solos. A calagem pode atenuar o problema da fixação porque, com a elevação do $\mathrm{pH}$, há um aumento da solubilidade dos fosfatos de ferro e alumínio e uma redução na adsorção do ânion fosfato à fase sólida do solo.

Outra prática que poderia favorecer o aproveitamento do fósforo em solos ácidos é o emprego de fosfatos silicatados, caso do termofosfato magnesiano. Este fertilizante é obtido pela fusão da rocha fosfatada com silicato de magnésio, o que destrói a estrutura cristalina da rocha e torna o fósforo mais solúvel e mais disponível ao vegetal. $\mathrm{O}$ termofosfato magnesiano exerce dois efeitos importantes no solo: eleva o $\mathrm{pH}$, por ser alcalino, e fornece silicato, um ânion capaz de competir com o fosfato pelos mesmos sítios de adsorção nos colóides.

Segundo a literatura, o efeito favorável do termofosfato magnesiano pode ser explicado das seguintes maneiras: neutralização da acidez do solo; fornecimento de cálcio e magnésio como nutrientes; adição de micronutrientes; diminuição na toxicidade do $\mathrm{Mn}$ pelo silicato presente e diminuição da fixação de fósforo pelo silicato. Diversos trabalhos tem demonstrado que, em muitas ocasiões, o termosfosfato é mais eficiente que os fosfatos solúveis em água, porém, as informações disponíveis são insuficientes para se afirmar se 
o efeito favorável desse fertilizante se deve mais ao aumento do $\mathrm{pH}$ ou à competição entre os ânions silicato e fosfato no complexo coloidal do solo.

Este estudo foi realizado com a finalidade de avaliar se o efeito favorável do termofosfato magnesiano sobre a absorção de fósforo e produção de matéria seca pelas plantas deve-se (a) à menor "fixação" do fósforo causada pela elevação do $\mathrm{pH}$, já que o termofosfato é um fertilizante alcalino ou (b) à competição entre o silicato contido no termofosfato e o fosfato, pelos mesmos sítios de adsorção no solo ou (c) a ambos esses efeitos. 


\section{REVISÃO DE LITERATURA}

\subsection{O fósforo no solo}

No solo o fósforo ocorre quase exclusivamente como ânion ortofosfato. $\mathrm{O}$ conteúdo total desse nutriente no solo varia, em média, de 0,02 a 0,15\% (MENGEL e KIRKBY, 1982). Parte do fósforo do solo encontra-se associada à matéria orgânica e parte constituindo compostos inorgânicos bastante insolúveis. A proporção entre essas duas formas é muito variável, podendo o fósforo orgânico representar mais da metade do teor total na camada arável (CABALA e FASSBENDER, 1970). As formas inorgânicas de fósforo são, em geral, as que representam interesse direto para a nutrição das plantas, podendo ser agrupadas nas formas de fosfato de alumínio ( $\mathrm{P}-\mathrm{Al}$ ), fosfato de ferro ( $\mathrm{P}-\mathrm{Fe}$ ), fosfato de cálcio $(\mathrm{P}-\mathrm{Ca})$, fosfatos oclusos de ferro e alumínio e $\mathrm{P}$ solúvel em água.

As formas inorgânicas de fósforo mais conhecidas em solos ácidos são as de $\mathrm{P}$ ligado ao $\mathrm{Fe} \mathrm{e}$ ao $\mathrm{Al}$, representadas pelos minerais estrengita e variscita, respectivamente. A transformação de uma forma de fosfato em outra é controlada principalmente pelo $\mathrm{pH}$. À medida que os solos se tornam mais ácidos, a atividade do $\mathrm{Fe}$ e do $\mathrm{Al}$ aumenta e as formas mais solúveis de $\mathrm{P}-\mathrm{Ca}$ são convertidas em $\mathrm{P}-\mathrm{Al}$ e $\mathrm{P}-\mathrm{Fe}$ (CHANG e JACKSON, 1958).

Do ponto de vista nutricional, podem ser reconhecidas no solo três frações de fósforo muito importantes no estudo da disponibilidade desse nutriente, conforme mostra 
o esquema geral abaixo, representando o formecimento de fósforo às plantas (MALAVOLTA, 1976):

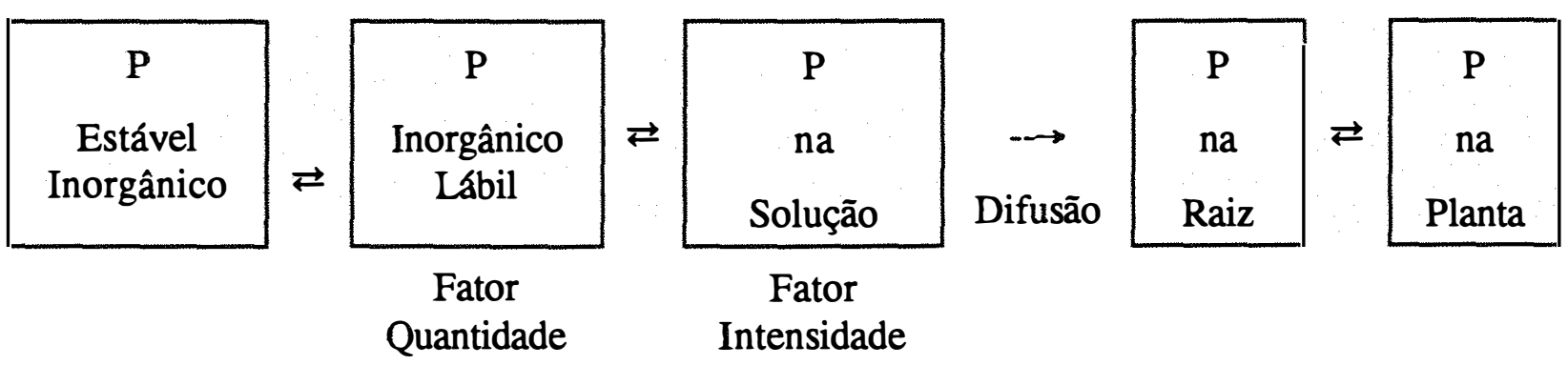

$\mathrm{O}$ P(solução) representa o fósforo dissolvido e fazendo parte da fase líquida do solo, sendo normalmente encontrado em concentraçōes muito baixas, da ordem de 0,1 a 1,0 ppm (LARSEN, 1967). As plantas absorvem fósforo da solução, o qual se movimenta até a superfície das raízes por difusão devido ao gradiente de concentração dos íons fosfato na solução. Daí a importância da manutenção de um nível adequado de fósforo na solução do solo.

Parte do fósforo da fase sólida, denominada por LARSEN (1967) de "P-lábil", mantém um equilíbrio rápido com o fósforo da solução do solo. A parte restante da fase sólida, denominada "P-não lábil", pode ser liberada muito lentamente e entrar em equilíbrio com o fósforo do reservatório lábil (MENGEL e KIRKBY, 1982); em prazos maiores, pode entrar em equilifbrio com o fósforo da solução.

\subsection{O sîlicio no solo e na planta}

O silício é o segundo elemento mais abundante em massa na crosta terrestre, sendo componente majoritário de minerais do grupo dos silicatos. Em solos, ocorre principalmente no mineral inerte das areias, o quartzo $\left(\mathrm{SiO}_{2}\right)$, bem como na caulinita e em outros minerais de argila (RAIJ, 1991). 
O conteúdo de silício nos solos é bastante variável, sendo comuns teores de 23 a $35 \%$ de Si (LINDSAY, 1979). Os teores nos solos do Estado de São Paulo variam de $0,3 \%$ a $33,7 \%$ de $\mathrm{SiO}_{2}$ (BRASIL, 1960).

Os teores totais de silício na fração argila diminuem com o grau de intemperismo. $\mathrm{O}$ aumento de intensidade do intemperismo provoca maior alteração dos minerais primários, com conseqüente perda dos elementos mais solúveis $(\mathrm{Ca}, \mathrm{Mg}, \mathrm{Na}, \mathrm{K}$, etc.) e posterior dessilicação desses minerais. Este é o processo de formação de solos latossólicos, que possuem, como minerais predominantes, argilas cauliníticas e óxidos e hidróxidos de Fe e Al (DEMATTÊ, 1987).

Os silicatos podem ser classificados de acordo com a forma das ligações das unidades tetraédricas $\mathrm{SiO}_{4}{ }^{-4}$. Com a decomposição dos silicatos, o silício entra na solução do solo sob a forma de ácido monossilícico $\mathrm{Si}(\mathrm{OH})_{4}$, desde que o $\mathrm{pH}$ esteja abaixo de 9,0 (McKEAGUE e CLINE, 1963a e 1963b; SANTOS, 1975; MALAVOLTA, 1980).

Como resultado do processo de intemperização, o silício ocorre na solução do solo como sílica hidratada $\left(\mathrm{SiO}_{2} \cdot \mathrm{nH}_{2} \mathrm{O}\right)$, como monômero de silício $\left(\mathrm{H}_{4} \mathrm{SiO}_{4}\right)$ e como íon silicato $\left(\mathrm{H}_{3} \mathrm{SiO}_{4}\right)^{-}$, bem como na forma coloidal (MALAVOLTA, 1976).

A solubilidade da sílica (gel $\mathrm{SiO}_{2}$ ) diminui com o aumento da acidez do solo, ocorrendo, ainda, precipitação do $\mathrm{SiO}_{2}$ quando a concentração da solução aumenta (Correns ${ }^{1}$, citado por BESOAIN, 1985). Esta é a razão pela qual em muitos solos se encontram geis de $\mathrm{SiO}_{2}$. Ao $\mathrm{pH} 8,0$ a solubilidade do $\mathrm{SiO}_{2}$ se reduz a um quarto da que tem ao $\mathrm{pH} 10.0$.

$\mathrm{O} \mathrm{pH}$ tem um efeito importante na solubilidade da sílica em água. Por algum tempo considerou-se que a solubilidade da sílica $\left(\mathrm{gel}_{\mathrm{SiO}}\right)$ aumentava com a elevação do pH de 3,0 a 8,0 (Correns ${ }^{1}$, citado por BESOAIN, 1985). Contudo, trabalhos mais recentes

\footnotetext{
${ }^{1}$ CORRENS, C.W. Sobre los minerales de las arcillas. Arales Edafol. y Fis. Veget., XI(3):283-290, 1952.
} 
(Alexander et al. ${ }^{1}$ e Okamoto et $\mathrm{al}^{2}$, citados por BESOAIN (1985), indicam que a solubilidade da sílica (cristalina ou amorfa) é independente do $\mathrm{pH}$ quando este se situa abaixo de 9,0, mas aumenta fortemente acima desse valor.

JONES \& HANDRECK (1963) e MCKEAGUE \& CLINE (1963a e 1963b) verificaram que a solubilidade do $\mathrm{Si}(\mathrm{OH})_{4}$ no solo é primeiramente controlada por sua adsorção nas superfícies de minerais, e que as reações de adsorção, entretanto, são influenciadas pelo $\mathrm{pH}$ do solo, pela temperatura e pela natureza das faces que adsorvem; destacam ainda que a concentração de $\mathrm{Si}(\mathrm{OH})_{4}$ cresce com o aumento da temperatura e a diminuição do $\mathrm{pH}$.

O teor de silício na solução do solo é resultante da solubilização dos compostos sólidos contendo silício, presentes no meio. Assim, a concentração de sílica na solução do solo deve ser bastante variável. CASTRO (1975) cita valores desde abaixo de 1 até acima de $20 \mathrm{ppm}$ de $\mathrm{SiO}_{2}$.

RAIJ \& CAMARGO (1973) verificaram que os teores de silica solúvel, extraível com $\mathrm{CaCl}_{2}$ 0,0025 $\mathrm{M}$, variaram de 2,2 a 92,2 ppm de $\mathrm{SiO}_{2}$, e que, para solos com teores semelhantes de argila, os teores de sílica solúvel foram maiores naqueles com horizonte B textural do que naqueles com horizonte B latossólico. Dentro de cada um desses grupos, os teores de sílica solúvel foram maiores para os solos mais argilosos. Carlisle et $\mathrm{al}^{3}$, citados por KABATA-PENDIAS \& PENDIAS (1984), relatam que a concentração de silício solúvel (principalmente como $\mathrm{H}_{4} \mathrm{SiO}_{4}$ ) na solução do solo é da ordem de 1 a $200 \mathrm{mg} / 1$.

'ALEXANDER, G.B.; HESTON, W.N. \& ILER, R.K. The solubility of amorphous silica in water. J. Phys. Chere., 58:453-455, 1954.

${ }^{2}$ OKAMOTO, G.; OKURA, T. \& GETO, K. Properties of silica in water. Geochimic Cosmochimic Acta, 12:123-132, 1957.

${ }^{3}$ CARLISLE, E.M.; McKEAGUE, J.A.; SIEVER, R. \& VAN SOEST, P.J. Silicon, in Geocheniston and the Environment. Vol. 2, Hopps, H.C., ed. NAS, Washington, D.C., 54. 1977. 
O mecanismo de absorção do silício pelas plantas aparentemente não está bem esclarecido. Segundo MALAVOLTA (1980), quando o pH está abaixo de 9,0 o $\mathrm{Si}$ é absorvido na forma de ácido monossilícico não dissociado. O processo parece ser ativo: é sensível a inibidores metabólicos e à temperatura; na seiva bruta do arroz o teor de $\mathrm{Si}$ é centenas de vezes mais alto que na solução externa, estando presente na forma do mesmo ácido monossilícico. A maior proporção do Si na planta, entretanto, é a de sílica amorfa hidratada, $\mathrm{SiO}_{2} \cdot \mathrm{nH}_{2} \mathrm{O}$. Em espécies de cerrado, particularmente gramíneas, é comum o aparecimento de corpos silicosos insolúveis.

Frey-Wyssling ${ }^{1}$, citado por JONES \& HANDRECK (1967), relata que o silício é absorvido pelas gramíneas através de fluxo de massa por processo não seletivo. $O$ silício absorvido acumula-se nas células epidérmicas, aparentemente proporcionando uma certa resistência às doenças. Segundo JONES \& HANDRECK (1967), quase a metade da sílica total da parte aérea localiza-se nas inflorescências, o restante distribuindo-se entre as folhas e os colmos. Plantas dicotiledôneas, por outro lado, têm mecanismo que evita a absorção de quantidades elevadas de silício. A esse respeito, MALAVOLTA (1980) relata que a distribuição do Si depende muito da espécie: é uniforme nas plantas que acumulam pouco silício, mas em outras há maior proporção nas raízes; em plantas com muito silício, como arroz, cerca de $90 \%$ estão na parte aérea.

Segundo MENGEL \& KIRKBY (1982), os cereais e gramíneas contém de 0,2 a $2 \%$ de silício na matéria seca, enquanto as dicotiledôneas encerram um décimo dessa quantidade ou menos. Em plantas com muito silício o teor pode chegar a 10\%. Em geral, tecidos mais velhos contêm maior teor de silício do que os mais jovens.

O silício tem sido considerado como nutriente essencial para certas culturas, principalmente gramíneas, nas quais os teores do elemento chegam a ser de 10 a 20 vezes maiores do que em dicotiledôneas. Os teores de silício na planta de arroz em solo inundado

\footnotetext{
${ }^{1}$ FREY-WYSSLING, A. Ber. Deut. Chem. Ges. 48:179-183, 1930.
} 
podem superar $5 \%$. Deficiências do elemento têm sido constatadas em solos ricos em óxidos hidratados de ferro e aluminio e pobres em sílica (RAIJ, 1991).

Com respeito à essencialidade do silício, MALAVOLTA (1980) relata que publicações mais antigas já mencionavam ser o silício responsável pelo "melhor crescimento" em diversas espécies, tanto nas mono quanto nas dicotiledôenas, observandose às vezes sintomas de anormalidade com a ausência do elemento ou quando este era fornecido em pequena quantidade. Aceitava-se que o $\mathrm{Si}$ desempenhasse um papel na resistência da planta ao ataque de fungos, o que torna difícil afirmar se o efeito era direto ou indireto. Por isso, o silício tem sido considerado como benéfico ou útil por alguns, essencial por outros e não essencial por outros mais.

A ação do silício na planta tem sido associada a efeitos indiretos, dentre os quais se destacam a resistência que confere às plantas ao ataque de pragas e moléstias, a influência que exerce na absorção de outros elementos e o efeito que tem na postura das folhas, as quais ficam menos curvas nas plantas mais bem supridas com silício. Também, o efeito desse elemento no crescimento vegetal parece estar relacionado às reações do mesmo com o fósforo no solo e na planta. A similaridade química entre os ânions desses elementos é o fator grandemente responsável por isso. Além disso, já há evidências de que o silício esteja envolvido no metabolismo do fósforo. Por outro lado, o silício tem sido pouco estudado, principalmente por não ser reconhecido como nutriente vegetal essencial. A falta de informações sobre sua forma de ação bioquímica talvez seja o motivo pelo qual esse elemento não desperta muito interesse nos pesquisadores.

OKUDA \& TAKAHASHI (1964) relataram que o silício é necessário para a cultura do arroz pelos seus efeitos fisiológicos, atuando durante o período de desenvolvimento da planta e na formação do grão. Segundo WERNER \& ROTH (1983), o arroz é a cultura mais freqüentemente estudada quando se pretende avaliar o efeito do silício sobre as peculiaridades fisiológicas. Os sintomas típicos de deficiência de silício são 
a necrose das folhas inferiores, atraso no crescimento, murchamento das folhas e aumento na velocidade de transpiração, que passa a ser $30 \%$ maior que a das plantas normais.

TISDALE et al. (1985) assinalam que o silício contribui para a estrutura das paredes celulares, concedendo dessa forma grande resistência dos vegetais ao ataque de doenças.

MARSCHNER (1986), que cita vários autores, entre outros efeitos benéficos da aplicação de silício, está a "movilização" que provoca no fósforo do solo, redução na perda de água via transpiração cuticular e incremento à resistência contra o ataque de pragas e doenças; e no futuro merecem mais atenção outras culturas, além de arroz e canade-açúcar. Além disso, o silício estimula o crescimento devido à prevenção ou diminuição na toxicidade de ferro ou manganês, sobretudo, em algumas espécies vegetais cultivadas sob inundação e com destaque para o arroz inundado.

\subsection{Interação entre silício e fósforo}

O efeito do silício no crescimento vegetal parece estar relacionado às reações deste elemento com o fósforo no solo e na planta (SILVA, 1971).

Certos ânions inorgânicos, como silicato, molibdato e sulfato, sãỏ adsorvidos quimicamente pelos minerais do solo e podem, em princípio, competir com o fosfato pelos sítios de adsorção. Assim, a correção da acidez do solo com silicatos, além de elevar o pH, poderia aumentar a disponibilidade de fósforo para as plantas pelo efeito adicional de deslocamento do fósforo adsorvido para a solução (ou bloqueamento dos sítios de adsorção) pelo silicato (VOLKWEISS e RAIJ, 1976; RAIJ, 1981). A respeito disso, HINGSTON et al. (1968 e 1972) relatam que, além do fosfato, o silicato e outros ânions como sulfato, bicarbonato, molibdato, selenito e nitrato, são capazes de coordenar-se com Fe e Al para formar compostos estáveis. Estes ânions devem, em princípio, ser capazes de competir com os ânions fosfatos pelos mesmos sítios de adsorção do solo. 
$\mathrm{O}$ aumento da carga negativa do solo com o aumento do $\mathrm{pH}$ pode acarretar a exclusão do ânion fosfato da proximidade da superfície do solo, acarretando assim uma menor fixação de fósforo, resultando em maior disponibilidade desse elemento para as plantas (CAMARGO et al., 1976).

SMYTH (1976) observou aumentos na capacidade de troca catiônica (CTC) em solos com minerais com potencial de superfície constante, pela aplicação de óxido de cálcio, silicato ou fósforo. Concluiu que aumentos na carga negativa por aplicações de fósforo são atribuídos às reações específicas de adsorção. Aumentos nas cargas negativas pela aplicação de hidróxido de cálcio são causados pela maior adsorção das hidroxilas. Silicatos podem aumentar a carga negativa do solo pelo mesmo mecanismo.

O efeito favorável do silício na produção de algumas espécies vegetais nas condições de campo, deve-se, em parte, ao aumento que provoca na disponibilidade de fósforo; ao que parece, isto se deve à troca do fosfato fixado em sesquióxidos pelo íon silicato (MALAVOLTA, 1980). Além disso, evidências têm sido mostradas de que o silício teria papel no metabolismo do fósforo $\mathrm{e}$, ainda, de que silício e fósforo são adsorvidos nos mesmos sítios. A esse respeito, RAJAN (1975) observou que a adsorção de fósforo em frações minerais ocorreu pela substituição do silício adsorvido em baixas concentrações e do silício estrutural em altas concentrações.

KHALID e SILVA (1980) mostraram um efeito residual do silício na disponibilidade crescente de fósforo, em camadas superficiais de solos. SMYTH (1976), que relata outros autores, diz que dentre os ânions inorgânicos, o silicato foi o mais efetivo no aumento da disponibilidade do fósforo em solos aluviais da Índia.

Segundo PLUCKNETT (1972), a aplicação de silicato aumenta a solubilidade do fósforo no solo, diminui a fixação desse elemento contido nos fertilizantes fosfatados, corrige as deficiências de cálcio e magnésio e aumenta o pH do solo. Foi verificado por SCARSETH (1965) que a aplicação de quantidades crescentes de silicato de sódio em solos ácidos aumentava o teor de P na solução. ROY et al. (1971) observaram que a adição de 
doses crescentes de silicato de cálcio ("basic slag" da TVA) a solos havaianos diminuiu a adsorção de P. Esses efeitos tanto poderiam ser devidos a uma competição de silicatos pelos sítios de adsorção como a um aumento do $\mathrm{pH}$, ou ainda, a ambos esses fatores.

KAMPRATH (1977), trabalhando com Latossolo do Hawai, observou que, na presença do íon silicato, particularmente em solos com caulinita e óxidos hidratados de ferro e alumínio, é menor a quantidade de adubo fosfatado que se deve adicionar para se obter uma determinada concentração de fósforo na solução, constatando que existe uma diminuição na fixação de fósforo provocada pelo silicato. SMITH \& SANCHEZ (1980) encontraram aumentos no teor de fósforo disponível do solo com a adição de escórias e outros componentes silicatados.

OLIVEIRA (1984), trabalhando com amostras de dois latossolos (LRd e LEdm) do Estado de Minas Gerais, observou deslocamentos recíprocos de silicio e fósforo, tendo sido verificados, em termos porcentuais, maiores deslocamentos no LEdm. O silicio foi mais facilmente deslocável pelo fósforo do que o contrário.

A literatura apresenta alguns trabalhos de pesquisa nos quais tem sido demonstrado que a presença de silício aumenta o aproveitamento do fósforo aplicado no solo. ROTHBUHR \& SCOTT (1957), utilizando silício radioativo, mostraram que adição de fósforo reduz levemente a quantidade de silício absorvida pelo trigo, tendo o silicato acelerado a absorção de fósforo. Segundo esses autores, existe uma estreita relação entre o metabolismo do silício e do fósforo. Por outro lado, ENGEL (1958) observou um aumento na absorção de silício pelo trigo quando o silicato foi adicionado à solução nutritiva na presença de fósforo.

Hall e Morrison ${ }^{1}$, citados por COMHAIRE (1966), mostraram que a adição de silicato de sódio ao solo pode aumentar o crescimento vegetal em tomo de $40 \%$, e

\footnotetext{
${ }^{1}$ HALL, A.D. \& MORRISON, C.G.T. Proc. Roy. Soc. B77, 455-472, 1906.
} 
concluíram que a sílica aparentemente foi importante na utilização das reservas de fosfato do solo.

COMHAIRE (1966) cita a importância do silício para vários vegetais como arroz, sorgo e couve-flor. $O$ crescimento na produção foi tão grande que consideraram o silício um elemento importante para essas culturas. AYRES (1966) constatou que a aplicação de silicato de cálcio foi responsável pelo aumento do $\mathrm{pH}$ do solo e diminuição na absorção de manganês e alumínio. $\mathrm{O}$ autor sugere que algum nível mínimo de disponibilidade de silício no solo deve existir, o qual é essencial para o crescimento normal da cana-de-açúcar.

ALY (1966), cultivando cana-de-açúcar em vasos, constatou um aumento na absorção de silício pela aplicação de silicato em solução sem fósforo. A adição de silicato aumentou a disponbilidade de fósforo no solo, que sob condições de deficiência do elemento, seria acompanhado por aumentos de produtividade. Observou ainda que, para teores semelhantes de $\mathrm{P}$ nas plantas, aquelas tratadas com silicato desenvolveram-se melhor, indicando que o silício, possivelmente favoreça o aproveitamento do $\mathrm{P}$ pela planta em decorrência do aumento da disponibilidade no solo.

Em solos havaianos, SHERMANN (1969) obteve maior rendimento de matéria seca do capim sudão devido à aplicação de Si na forma de silicato de cálcio; notou-se neste trabalho que a resposta à aplicação de $\mathrm{P}$ pela cultura foi bem maior com a aplicação de silicato de cálcio do que com carbonato de cálcio; com aplicação da metade da dose de $\mathrm{P}$ nos vasos contendo silicato de cálcio, o rendimento do capim sudão foi superior ao obtido nos vasos contendo carbonato, mesmo quando maiores níveis de $\mathrm{P}$ eram fornecidos.

FASSBENDER \& MOLINA (1969), estudando o efeito de fertilizantes fosfatados sobre a produção de plantas de tomate e o $\mathrm{pH}$ de um solo da Costa Rica originado de cinzas vulcânicas, verificaram que os fertilizantes sílicofosfatados deram maiores produções do que o supertriplo finamente moido. As maiores produções foram 
atribuídas ao aumento do $\mathrm{pH}$ do solo, à diminuição do teor de alumínio trocável e ao aumento na disponibilidade do fósforo.

Segundo Roy ${ }^{1}$, citado por GURGEL (1979), a absorção de fósforo e silício pelas plantas cultivadas em solução nutritiva é função da espécie, sendo que a presença de silício e fósforo acelerou a absorção de $\mathrm{P}$ pelo alface e pelo milho, inibindo-a em arroz e cana-de-açúcar. De modo geral, a presença de fósforo inibiu a absorção de silício pelas plantas, sendo essa inibição maior quando o fósforo e o silício foram fornecidos às plantas na mesma proporção.

Como fontes de silício podem ser citadas as escórias de alto-fornos, constituídas de silicatos de cálcio e outros metais, o silicato de sódio e o termofosfato magnesiano; o elemento parece ter efeito positivo no crescimento vegetal e, por isso, vem sendo adicionado ao solo como fertilizante. MUNK (1983) aplicou de 200 a $800 \mathrm{~kg}$ de $\mathrm{SiO}_{2} / \mathrm{ha}$ em experimentos durante 5 anos, e conseguiu um aumento de $10 \%$ na produção de cereais e beterraba açucareira. MIYAKE \& TAKAHASHI (1983) observaram que em solo aluvial, a aplicação de 700 a $1400 \mathrm{~kg} \mathrm{SiO} /$ /ha por ano, promove maior desenvolvimento e produção de pepino e reduziu a incidência de doenças.

\subsection{Termofosfato magnesiano e seu uso}

O termofosfato magnesiano, também chamado de silicofosfato de magnésio, é obtido pelo aquecimento de uma mistura de rocha fosfatada com silicato de magnésio a uma temperatura de $1500^{\circ} \mathrm{C}$, provocando-se a seguir um choque térmico da massa em fusão com água fria. Finalmente, o material obtido é moído após secagem. A fusão da rocha fosfática a $1500^{\circ} \mathrm{C}$ destrói a estrutura cristalina da rocha, possibilitando as transformações físicas e reações químicas com formação de fósforo mais solúvel e mais disponível ao vegetal.

${ }^{1}$ ROY, A.C. Phosphorus-silicon interactions in soils and plants. Ph.D. Thesis, Univ. of Hawaii, 1969. 190p. 
Os produtos fosfatados provenientes do tratamento térmico são praticamente insolúveis em água mas solúveis em ácido cítrico ou em solução neutra de citrato de amônio, não sofrem empedramento e apresentam reação alcalina (ANDO, 1958; CHIEN, 1978; BRAUN, 1980). Essas características são responsáveis pela boa eficiência desses produtos, em comparação com a dos superfosfatos, quando aplicados em solos ácidos.

Segundo MALAVOLTA (1981), o termofosfato pode dar produções de 12 a $45 \%$ maiores que as obtidas com o superfosfato; esse efeito pode ser explicado de diferentes maneiras que não se excluem mutuamente: neutralização da acidez do solo; fornecimento de cálcio e magnésio como nutrientes; adição de micronutrientes; diminuição na toxicidez do Mn pelo silicato presente; diminuição da fixação de fósforo pelo silicato.

Resultados de 425 ensaios de campo, em diversas localidades dos E.U.A., mostraram que o fosfato tricálcico fundido, desenvolvido pelo TVA, pode igualar-se ao superfosfato triplo como fonte de fósforo para certas culturas, quando aplicados em solos ácidos. Já em solos alcalinos esse tipo de fosfato mostrou-se ineficiente (SEATZ et al., 1954).

MUZILLI et al. (1971) compararam os efeitos de doses crescentes aplicadas a lanço, de termofosfato mangnesiano, de termofosfato Rhenânia e do superfosfato simples, em solos ácidos do Sul do Paraná com saturação de alumínio de $80 \%$. O termofosfato Rhenânia mostrou boa eficiência tanto como fonte de fósforo quanto como atenuador dos efeitos da acidez; o termofosfato magnesiano mostrou melhor efeito na neutralização da acidez, mas não foi comparável ao Rhenânia no aumento da disponibilidade de fósforo. $\mathrm{O}$ superfosfato simples, embora tivesse aumentado satisfatoriamente a disponibilidade de fósforo, não mostrou efeitos na neutralização da acidez. Nesse estudo, o teor de fósforo solúvel foi determinado pelo método de Mehlich.

KAMINSKI (1983), cultivando sorgo em amostras de três solos ácidos, em casa de vegetação, verificou que o desempenho de um termofosfato magnesiano foi inferior ao 
do superfosfato simples, o qual, por sua vez, foi equivalente ao de um termofosfato do tipo Rhenânia.

Estudando a eficiência agronômica de onze fontes de fósforo em solos de cerrado durante oito anos, GOEDERT \& LOBATO (1984) concluiram que o termofosfato magnesiano e o hiperfosfato de Gafsa foram similares ao superfosfato triplo como fontes de fósforo para as plantas desde o primeiro cultivo, quando foram aplicados a lanço e incorporados ao solo.

Diversos trabalhos têm evidenciado os resultados satisfatórios apresentados pelo termofosfato magnesiano, os quais, em várias ocasiões, têm demonstrado ser tão eficientes quanto os fertilizantes solúveis em água (BORKERT et al., 1978; FEITOSA et al., 1978; GOEDERT \& LOBATO, 1983; GOEDERT et al., 1987).

Dados regionais apresentados por MALAVOLTA (1985) indicaram que a eficiência relativa das fontes de $\mathrm{P}_{2} \mathrm{O}_{5}$, em experimentos no Estado de São Paulo com cana-de-açúcar, obedeceu a ordem termosfato $>$ superfostato simples $>$ superfosfato triplo $>$ fosforita de Olinda $>$ fosfato Alvorada $>$ apatita de Araxá, e que o comportamento dos fosfatos solúveis (os três primeiros) seja possívelmente o mesmo do ponto de vista estatístico. 


\section{MATERIAL E MÉTODOS}

O experimento foi realizado em casa-de vegetação do Departamento de Ciência do Solo da Escola Superior de Agricultura "Luiz de Queiroz", Campus de Piracicaba, empregando-se delineamento experimental inteiramente casualizado, com tratamentos em arranjo fatorial $3 \times 4 \times 2$. Os fatores foram constituidos de três fontes de fósforo (termofosfato magnesiano, TM; superfosfato triplo, ST; e superfosfato triplo + corretivo de acidez, ST +CAL), quatro doses de fósforo $(0,50,100$ e $200 \mathrm{mg} / \mathrm{kg}$ de $\mathrm{P})$ e dois solos (Terra Roxa Estruturada, TE e Latossolo Roxo, LR), envolvendo 24 tratamentos; estes foram repetidos quatro vezes, totalizando 96 parcelas. As aplicações de TM resultaram adições de silício iguais a 157, 314 e $628 \mathrm{mg} / \mathrm{kg} \mathrm{de} \mathrm{SiO}_{2}$, respectivamente para cada dose. A unidade experimental foi constituída por um vaso de barro, com capacidade para $5,0 \mathrm{~kg}$ de terra.

\subsection{Localização, amostragem e caracterização dos solos}

Os solos situam-se em duas áreas do Estado de São Paulo, uma localizada no município de Piracicaba (solo TE) e a outra no município de Jardinópolis (solo LR). As amostras foram coletadas da camada superficial $(0-20 \mathrm{~cm})$, secadas ao ar, passadas em peneira com malha de $2 \mathrm{~mm}$ e homogeneizadas. As características físicas e químicas dos solos são apresentadas nas Tabelas 1 e 2 . 
Tabela 1 - Características físicas das amostras dos solos utilizadas no experimento

\begin{tabular}{cccccc}
\hline \hline Solo $^{(1)}$ & Argila & Silte & Areia & densidade do solo & Classe Textural \\
\cline { 2 - 5 } & & & & & \\
TE & 54,0 & 20,0 & 26,0 & 1,3 & argilosa \\
LR & 67,0 & 9,0 & 24,0 & 1,2 & muito argilosa \\
\hline \hline
\end{tabular}

(1) $\mathrm{TE}=$ Terra Roxa Estruturada; LR = Latossolo Roxo

A análise granulométrica foi feita pelo método do densímetro (Bouyoucos), e a densidade determinada pelo método do anel volumétrico; ambas as metodologias estão descritas em CAMARGO et al. (1986).

A caracterização química das amostras de solo para fins de fertilidade foi realizada através dos procedimentos analíticos descritos por RAIJ \& QUAGGIO (1983). Além dessas análises foi feita a determinação do enxofre por extração do $\mathrm{S}_{-} \mathrm{SO}_{4}$ pelo acetato de amônio em ácido acético e posterior medição pelo método turbidimétrico (VITTI, 1989). $\mathrm{O}$ ataque sulfúrico para a determinação dos elementos $\mathrm{SiO}_{2} \%, \mathrm{Al}_{2} \mathrm{O}_{3} \%$, $\mathrm{Fe}_{2} \mathrm{O}_{3}$ e $\mathrm{TiO}_{2} \%$ foi realizado conforme procedimentos de VETTORI (1969).

Ambos os solos apresentam na camada superficial baixa disponibilidade de fósforo, sendo o solo TE mais ácido que o LR (Tabela 2); os valores de CTC e V são mais altos no TE do que no LR. Segundo classificação de RESENDE \& SANTANA (1988), o $\mathrm{TE}$, com um $\mathrm{Ki}$ de 2,18 e um $\mathrm{Kr}$ de 0,77 , é considerado um solo caulinítico não sesquioxídico; o LR, por sua vez, com um Ki de 0,69 e um $\mathrm{Kr}$ de 0,40, é classificado como um solo gibsítico sesquioxídico. 
Tabela 2 - Características químicas das amostras dos solos utilizadas no experimento

\begin{tabular}{|c|c|c|c|}
\hline \multirow[b]{2}{*}{ Característica } & \multirow[b]{2}{*}{ Unidade } & \multicolumn{2}{|c|}{$\operatorname{SOLOS}^{(\mathfrak{i})}$} \\
\hline & & $\mathrm{TE}$ & LR \\
\hline Matéria orgânica & $\mathrm{g} / \mathrm{dm}^{3}$ & 37,0 & 23,0 \\
\hline $\mathrm{pH}$ em $\mathrm{CaCl}_{2}$ & - & 4,5 & 4,8 \\
\hline $\mathrm{Ca}^{2+}$ & $\mathrm{cmol}_{\mathrm{c}} / \mathrm{dm}^{3}$ & 3,4 & 0,8 \\
\hline $\mathrm{Mg}^{2+}$ & $\mathrm{cmol}_{\mathrm{c}} / \mathrm{dm}^{3}$ & 1,4 & 0,3 \\
\hline $\mathrm{K}^{+}$ & $\mathrm{cmol}_{\mathrm{c}} / \mathrm{dm}^{3}$ & 0,45 & 0,1 \\
\hline $\mathrm{Al}^{3+}$ & $\mathrm{cmol}_{\mathrm{c}} / \mathrm{dm}^{3}$ & 0,3 & 0,0 \\
\hline $\mathrm{H}^{+}+\mathrm{Al}^{3+}$ & $\mathrm{cmol}_{\mathrm{c}} / \mathrm{dm}^{3}$ & 5,1 & 3,0 \\
\hline SB & $\mathrm{cmol}_{\mathrm{c}} / \mathrm{dm}^{3}$ & 5,3 & 1,2 \\
\hline СТC & $\mathrm{cmol}_{\mathrm{c}} / \mathrm{dm}^{3}$ & 10,4 & 4,2 \\
\hline $\mathrm{S}-\mathrm{SO}_{4}$ & $\mu \mathrm{g} / \mathrm{cm}^{3}$ & 37,0 & 56,0 \\
\hline V & $\%$ & 51,0 & 29,0 \\
\hline $\mathrm{m}$ & $\%$ & 5,4 & 0,0 \\
\hline $\mathrm{SiO}_{2}$ & $\%$ & 14,70 & 6,74 \\
\hline $\mathrm{Al}_{2} \mathrm{O}_{3}$ & $\%$ & 11,48 & 16,62 \\
\hline $\mathrm{Fe}_{2} \mathrm{O}_{3}$ & $\%$ & 32,74 & 18,50 \\
\hline $\mathrm{TiO}_{2}$ & $\%$ & 6,90 & 7,74 \\
\hline $\mathrm{Kr}$ & - & 0,77 & 0,40 \\
\hline $\mathrm{Ki}$ & - & 2,18 & 0,69 \\
\hline P-resina & $\mu \mathrm{g} / \mathrm{cm}^{3}$ & 8,5 & 3,0 \\
\hline P-Bray-1 & $\mu \mathrm{g} / \mathrm{g}$ & 3,01 & 1,32 \\
\hline sílica solúvel $\left(\mathrm{SiO}_{2}\right)$ & $\mu \mathrm{g} / \mathrm{g}$ & 45,25 & 15,10 \\
\hline
\end{tabular}

(1) $\mathrm{TE}=$ Terra Roxa Estruturada; LR = Latossolo Roxo. 


\subsection{Caracterização das fontes de fósforo e do corretivo de acidez}

Segundo análises realizadas pelos métodos oficiais de análises de corretivos, fertilizantes e inoculantes (BRASIL, 1988), o TM, denominado comercialmente "MGYOORIN", apresentou $18,19 \%$ de $\mathrm{P}_{2} \mathrm{O}_{5}$ total e $17,30 \%$ de $\mathrm{P}_{2} \mathrm{O}_{5}$ solúvel em ácido cítrico a $2 \%$ (relação 1:100); apresentou, ainda, $25 \%$ de $\mathrm{SiO}_{2}$, dos quais mais de $90 \%$ solúveis em ácido cítrico a $2 \%, 28 \%$ de $\mathrm{CaO}$ e $15 \%$ de $\mathrm{MgO}$. O ST continha $47,63 \%$ de $\mathrm{P}_{2} \mathrm{O}_{5}$ total, $44,98 \%$ de $\mathrm{P}_{2} \mathrm{O}_{5}$ solúveis em solução neutra de citrato de amônio + água, 37,0\% de $\mathrm{P}_{2} \mathrm{O}_{5}$ solúveis em água e $17 \%$ de $\mathrm{CaO}$.

A assim chamada "fonte $S T+C A L "$ constituiu um tratamento no qual as amostras receberam o ST e uma mistura de carbonato de cálcio e carbonato de magnésio (produtos p.a.), na proporção de quatro equivalentes de $\mathrm{CaCO}_{3}$ para um equivalente de $\mathrm{MgCO}_{3}$. As quantidades da mistura de carbonatos foram calculadas através de curvas de neutralização e equivalem ao poder neutralizante das diferentes doses de TM.

\subsection{Obtenção das curvas de neutralização}

Foram feitas duas curvas de neutralização, uma para o TM e outra para o $\mathrm{CaCO}_{3}$; para isso, amostras de cada solo foram misturadas com as diferentes doses de fósforo na forma de TM, e outro grupo de amostras misturadas com quantidades crescentes de $\mathrm{CaCO}_{3}$ p.a., umedecidas e incubadas; aos 7, 11, 14 e 18 dias o $\mathrm{pH}$ foi medido em solução de $\mathrm{CaCl}_{2}$ 0,01 M. Os Apêndices 1 e 2 mostram as curvas de neutralização obtidas com o TM e o $\mathrm{CaCO}_{3}$, respectivamente, após 18 dias de incubação.

Para cada solo, as quantidades de $\mathrm{CaCO}_{3}$ correspondentes ao poder neutralizante das diferentes doses de TM foram obtidas através das equações do Apêndice 1, calculandose os valores de $\mathrm{pH}$ atingidos com as diferentes doses de TM; estes valores de $\mathrm{pH}$ foram introduzidos nas equações do Apêndice 2, obtendo-se as quantidades de $\mathrm{CaCO}_{3}$ para cada valor de $\mathrm{pH}$ do TM. 


\subsection{Instalação e condução do experimento}

Para constituir os tratamentos, amostras de 5,5 kg de terra foram intimamente misturadas com o TM, o ST e a mistura de corretivos; no caso do tratamento ST + CAL, o ST e a mistura de corretivos foram aplicados separadamente. As amostras foram umedecidas a $70 \%$ da capacidade de retenção de água e incubadas em vasos de barro previamente impermeabilizados com "neutrol", por um período de 20 dias. Os fosfatos foram aplicados na forma de pó. As amostras foram irrigadas periodicamente para manter a umidade do solo.

Após a incubação, as amostras foram novamente secadas ao ar, destorroadas e passadas em peneira de $2 \mathrm{~mm}$ de abertura de malha; subamostras de $0,5 \mathrm{~kg}$ foram retiradas para análises. Uma adubação básica e uniforme a todos os tratamentos foi realizada aplicando-se a cada porção de $5 \mathrm{~kg}$ de terra restantes, na forma de solução, 900 $\mathrm{mg}$ de $\mathrm{N}$ na forma de nirrato de amônio em ambos os solos e 187,5 mg de $\mathrm{K}$ para o TE e $750 \mathrm{mg}$ de $\mathrm{K}$ para o LR, na forma de cloreto de potássio; essas doses foram parceladas em três aplicações, sendo uma no plantio e duas aos 20 e 40 dias após a primeira aplicação. Foram fornecidos também os seguintes micronutrientes nas respectivas doses, em mg/kg do elemento: B (1), $\mathrm{Cu}$ (1), Mo (0,1), Mn (2), $\mathrm{Zn}$ (5) e Fe (5); esses micronutrientes foram aplicados nas formas de $\mathrm{H}_{3} \mathrm{BO}_{3}, \mathrm{CuCl}_{2} \cdot 2 \mathrm{H}_{2} \mathrm{O}$, $\left(\mathrm{NH}_{4}\right) 6 \mathrm{Mo}_{7} \mathrm{O}_{24} \cdot \mathrm{H}_{2} \mathrm{O}$, $\mathrm{MnCl}_{2} \cdot 4 \mathrm{H}_{2} \mathrm{O}, \mathrm{ZnSO}_{4} \cdot 7 \mathrm{H}_{2} \mathrm{O}$ e $\mathrm{FeSO}_{4} \cdot 7 \mathrm{H}_{2} \mathrm{O}+$ EDTA.

Nos tratamentos sem TM e sem corretivo foi aplicada uma solução contendo $\mathrm{CaCl}_{2} \cdot 2 \mathrm{H}_{2} \mathrm{O}$ e $\mathrm{MgCl}_{2} \cdot 6 \mathrm{H}_{2} \mathrm{O}$, na proporção de quatro equivalentes de cálcio para um de magnésio, em quantidades correspondentes àquelas aplicadas como corretivo, com o objetivo de fornecer esses nutrientes para as plantas.

Após homogeneização, as terras foram retornadas aos vasos de barro e umedecidas a $70 \%$ da capacidade máxima de retenção de água. Dezesseis sementes de arroz (Oriza sativa L.), cultivar IAC 165, foram plantadas em cada vaso, desbastando-se posteriormente para oito plantas. 
Aos 75 dias após a semeadura, a parte aérea das plantas foi cortada rente ao solo e o material acondicionado em sacos de papel, secado em estufa de ventilação forçada a $65^{\circ} \mathrm{C}$, pesado e passado em moinho com peneira de 20 mesh.

\subsection{Análise química das amostras de solo}

\subsection{1. pH, cátions trocáveis e acidez potencial}

Foram realizadas análises químicas para determinação do $\mathrm{pH}$ em $\mathrm{CaCl}_{2} 0,01 \mathrm{M}$ e dos teores de $\mathrm{K}^{+}, \mathrm{Ca}^{2+}, \mathrm{Mg}^{2+}, \mathrm{Al}^{3+}$ e $\mathrm{H}^{+}+\mathrm{Al}^{3+}$, segundo procedimentos analíticos descritos por RAIJ \& QUAGGIO (1983); com esses valores foi calculada a saturação por bases (V).

\subsubsection{Fósforo extraído pelo método da resina}

Foi utilizado o método da resina trocadora de íons, saturada com bicarbonato de sódio $1 \mathrm{~N}$ a pH 8,5 (RAIJ \& QUAGGIO, 1983). Em resumo, o método consta da extração do fósforo por uma mistura de volumes iguais de resinas Amberlite IRA-400 (base forte) e Amberlite IRA-120 (ácido forte), previamente passadas em peneira com abertura de $0,5 \mathrm{~mm}$. Foram transferidos $2,5 \mathrm{~cm}^{3}$ de terra para frasco plástico de $80 \mathrm{ml}$, provido de tampa, acrescentando-se $25 \mathrm{ml}$ de água destilada, uma esfera de vidro e agitando-se por 15 minutos em agitador rotativo horizontal. Após adição de $2,5 \mathrm{~cm}^{3}$ de resina regenerada, o frasco foi agitado por mais 16 horas. Em seguida, a resina foi lavada com água para retirar a argila e transferida para frasco de $100 \mathrm{ml}$. O fósforo adsorvido à resina foi extraído acrescentando-se $50 \mathrm{ml}$ de solução de $\mathrm{NH}_{4} \mathrm{Cl} 0,8 \mathrm{~N}+\mathrm{HCl} 0,2 \mathrm{~N}$, deixando-se a mistura em repouso por 30 minutos para eliminar o gás carbônico e agitando-a em seguida por uma hora. $\mathrm{O}$ teor de fósforo no extrato foi determinado através do método colorímetro de MURPHY \& RILEY (1962). 


\subsubsection{Fósforo extraído pelo método Bray-1}

O método emprega solução de $\mathrm{NH}_{4} \mathrm{~F}$ 0,03N e $\mathrm{HCl}$ 0,025N (BRAY \& KURTZ, 1945). Para a extração, $7 \mathrm{~g}$ de terra foram agitados com $50 \mathrm{ml}$ de solução extratora por um minuto. A suspensão foi filtrada e o teor de fósforo no extrato foi determinado através do método colorímetro de MURPHY \& RILEY (1962).

\subsubsection{Sîica solúvel}

A extração da sílica foi realizada conforme RAIJ \& CAMARGO (1973). Dez gramas de terra foram agitados com $100 \mathrm{ml}$ de cloreto de cálcio $0,0025 \mathrm{M}$ por 5 minutos. Após repouso por 14 horas, a suspensão foi filtrada. $O$ teor de sílica foi determinado em alíquotas de $50 \mathrm{ml}$ empregando-se o método colorimétrico descrito por KILMER (1965), com duas modificações: (a) a solução-padrão de sílica foi preparada empregando-se metasilicato de sódio $\left(\mathrm{Na}_{2} \mathrm{SiO}_{3} .5 \mathrm{H}_{2} \mathrm{O}\right)$, ao invés do silicato de sódio obtido por fusão do quartzo $\left(\mathrm{SiO}_{2}\right)$ com carbonato de sódio e (b) o ácido ascórbico foi utilizado como redutor, ao invés do ácido 1-amino-2-naftol-4-sulfônico.

\subsection{Análise do material vegetal}

\subsubsection{Teor de fósforo}

A concentração de fósforo nos tecidos das plantas foi determinada por via úmida, de acordo com metodologia descrita por SARRUGE \& HAAG (1974). Amostras de $1 \mathrm{~g}$ do material vegetal foram submetidas à digestão por mistura de ácidos nítrico e perclórico, na proporção de $20 \mathrm{ml}$ de $\mathrm{HNO}_{3}$ para $2 \mathrm{ml} \mathrm{de} \mathrm{HClO}_{4}$. O fósforo foi então determinado pelo método colorimétrico empregando-se o vanadato-molibdato.

\subsubsection{Teor de silício}

A concentração de silício no material vegetal foi determinada conforme metodologia descrita por BATAGLIA et al. (1983). O princípio do método consiste na 
fusão das cinzas do material vegetal com hidróxido de sódio e determinação do silício pelo método colorimétrico do azul de molibdênio, em presença do ácido oxálico e do ácido ascórbico.

\subsection{Parâmetros avaliados e análises estatísticas}

Os parâmetros de solo avaliados foram: $\mathrm{pH}$ medido em solução centimolar de cloreto de cálcio, saturação por bases $(\mathrm{V})$, fósforo extraído pelo método da resina, fósforo extraído pelo método de Bray-1 e sílica solúvel.

Os parâmetros da planta, todos relativos à parte aérea, foram: produção de matéria seca, teores de fósforo e silício e quantidades acumuladas de fósforo e silício.

O efeito dos tratamentos foi estudado estatisticamente através de análises de variância dos resultados. As médias dos fatores qualitativos (solos e fontes de fósforo) foram comparadas pelo teste de Tukey ao nível de $5 \%$ de probabilidade. O efeito das doses de fósforo foi avaliado por regressão polinomial. Também foram realizadas análises de correlação linear para os principais parâmetros de planta e solo. 


\section{RESULTADOS E DISCUSSÃO}

\subsection{Parâmetros do solo}

\subsection{1. $\mathbf{p H}$ em $\mathrm{CaCl}_{2}$ e Saturação por Bases}

A análise de variância para os valores de $\mathrm{pH}$ em $\mathrm{CaCl}_{2}$ mostrou efeito significativo dos três fatores estudados (solos, fontes de fósforo e doses de fósforo) e das três interações duplas (solos $\mathrm{x}$ fontes, solos $\mathrm{x}$ doses e fontes $\mathrm{x}$ doses) (Tabela 3); o efeito da interação tripla não foi significativo. Comparando-se os dois solos observa-se que, para a média de todas as fontes de fósforo aplicadas, e em todas as doses de $\mathrm{P}$, os valores de $\mathrm{pH}$ em $\mathrm{CaCl}_{2}$ encontrados no LR foram significativamente superiores aos obtidos no TE (Tabela 4). Porém, como o aumento máximo de pH observado no LR (de 4,89 a 5,71) foi maior que o obtido no TE (de 4,48 a 5,07), presume-se que este seja mais tamponado que aquele; essa afirmação está coerente com o que se poderia esperar considerando-se as propriedades de cada solo (Tabela 2), visto que os valores de CTC, teor de matéria orgânica e acidez potencial são maiores no TE que no LR.

Os valores de $\mathrm{pH}$ em $\mathrm{CaCl}_{2}$ obtidos após a aplicação das fontes fosfatadas TM e ST+CAL foram sempre maiores que os verificados com a adição de ST (Tabela 5). O estudo de regressões polinomiais permitiu verificar que as fontes TM e ST+CAL elevaram de modo semelhante o pH do solo, tanto mais quanto maior foi a dose aplicada (Figura 1a). 
O pH aumentou, respectivamente, de 4,7 para até 5,7 com a adição do TM, e de 4,6 para até 5,8 com a aplicação do ST +CAL; o ST, por sua vez, causou decréscimo pequeno no pH. O aumento de $\mathrm{pH}$ em $\mathrm{CaCl}_{2}$ com a adição das fontes fosfatadas foi linear no solo TE e quadrático no LR (Figura 1b).

Tabela 3 - Valores de $\mathrm{F}$ e coeficientes de variação (CV) para valores de $\mathrm{pH}$ em $\mathrm{CaCl}_{2}$, saturação por bases (V), teores de $\mathrm{P}$ extraídos pelos métodos da resina e Bray-1 e teores de sílica solúvel, de amostras de dois solos tratadas com diferentes fontes e doses de fósforo ${ }^{(1)}$.

\begin{tabular}{llllll}
\hline \hline $\begin{array}{l}\text { Causa de } \\
\text { variação }\end{array}$ & $\begin{array}{c}\mathrm{pH} \mathrm{em} \\
\mathrm{CaCl}_{2}\end{array}$ & $\mathrm{~V}$ & P-Resina & $\mathrm{P}$-Bray-1 & $\mathrm{SiO}_{2}$ \\
\hline
\end{tabular}

\begin{tabular}{lcrrrr} 
& \multicolumn{5}{c}{ Valor de F } \\
Solos (S) & $752,98^{* *}$ & $427,88^{* *}$ & $19,92^{* *}$ & $34,22^{* *}$ & $41456,32^{* *}$ \\
Fontes (F) & $247,33^{* *}$ & $298,70^{* *}$ & $22,31^{* *}$ & $36,91^{* *}$ & $1794,90^{* *}$ \\
Doses (D) & $246,33^{* *}$ & $273,03^{* *}$ & $554,69^{* *}$ & $3751,00^{* *}$ & $280,20^{* *}$ \\
S x F & $10,81^{* *}$ & $11,74^{* *}$ & 1,99 & $13,06^{* *}$ & $11,09^{* *}$ \\
S x D & $6,01^{* *}$ & $16,99^{* *}$ & $34,08^{* *}$ & $52,32^{* *}$ & $14,01^{* *}$ \\
F x D & $72,46^{* *}$ & $57,02^{* *}$ & $7,68^{* *}$ & $13,41^{* *}$ & $309,45^{* *}$ \\
S x F x D & 1,70 & $5,36^{* *}$ & 0,91 & $6,25^{* *}$ & $12,66^{* *}$ \\
& & & & & \\
& & & CV $(\%)$ & & \\
& 1,9 & 5,4 & 19,1 & 7,1 & \\
\hline \hline
\end{tabular}

(1) valor significativo a $1 \%$. 
Tabela 4 - Valores de $\mathrm{pH}$ em $\mathrm{CaCl}_{2}$ de amostras de Terra Roxa Estruturada (TE) e Latossolo Roxo (LR) tratadas com diferentes doses de fósforo (média de quatro repetições e de três fontes fosfatadas: termofosfato magnesiano, superfosfato triplo + calcário e superfosfato triplo) ${ }^{(1)}$

\begin{tabular}{lcccc}
\hline \hline & \multicolumn{4}{c}{ Dose de fósforo $(\mathrm{mg} / \mathrm{kg}$ de P) } \\
\cline { 2 - 5 } Solo & 0 & 50 & 100 & 200 \\
\hline & & & & \\
$\mathrm{TE}$ & $4,48 \mathrm{bD}$ & $4,64 \mathrm{bC}$ & $4,83 \mathrm{bB}$ & $5,07 \mathrm{bA}$ \\
$\mathrm{LR}$ & $4,89 \mathrm{aD}$ & $5,14 \mathrm{aC}$ & $5,38 \mathrm{aB}$ & $5,71 \mathrm{aA}$ \\
\hline \hline
\end{tabular}

${ }^{(1)}$ Médias seguidas por letras iguais, minúsculas dentro de cada dose e maíusculas dentro de cada solo, não diferem entre si pelo teste de Tukey ao nivel de $5 \%$ de probabilidade.

Tabela 5 - Valores $\mathrm{pH}$ em $\mathrm{CaCl}_{2}$ de amostras de solo tratadas com diferentes doses e fontes de fósforo (médias de quatro repetições e de dois solos, Terra Roxa Estruturada e Latossolo Roxo) ${ }^{(1)}$

\begin{tabular}{lcccc}
\hline \hline \multirow{2}{*}{ onte $^{(2)}$} & \multicolumn{4}{c}{ Dose de fósforo $(\mathrm{mg} / \mathrm{kg}$ de P) } \\
\cline { 2 - 5 } & 0 & 50 & 100 & 200 \\
\hline & & & & \\
TM & $4,66 \mathrm{aD}$ & $4,99 \mathrm{aC}$ & $5,33 \mathrm{aB}$ & $5,70 \mathrm{aA}$ \\
ST+CAL & $4,64 \mathrm{aD}$ & $4,98 \mathrm{aC}$ & $5,29 \mathrm{aB}$ & $5,78 \mathrm{aA}$ \\
ST & $4,75 \mathrm{aA}$ & $4,71 \mathrm{bA}$ & $4,71 \mathrm{bA}$ & $4,69 \mathrm{bA}$ \\
\hline \hline
\end{tabular}

${ }^{(1)}$ Médias seguidas por letras iguais, minúsculas dentro de cada dose e maíusculas dentro de cada fonte, não diferem entre si pelo teste de Tukey ao nível de $5 \%$ de probabilidade.

(2)TM, termofosfato magnesiano; ST, superfosfato triplo; CAL, mistura de $\mathrm{CaCO}_{3}$ e $\mathrm{MgCO}_{3}$ na relação 4:1. 

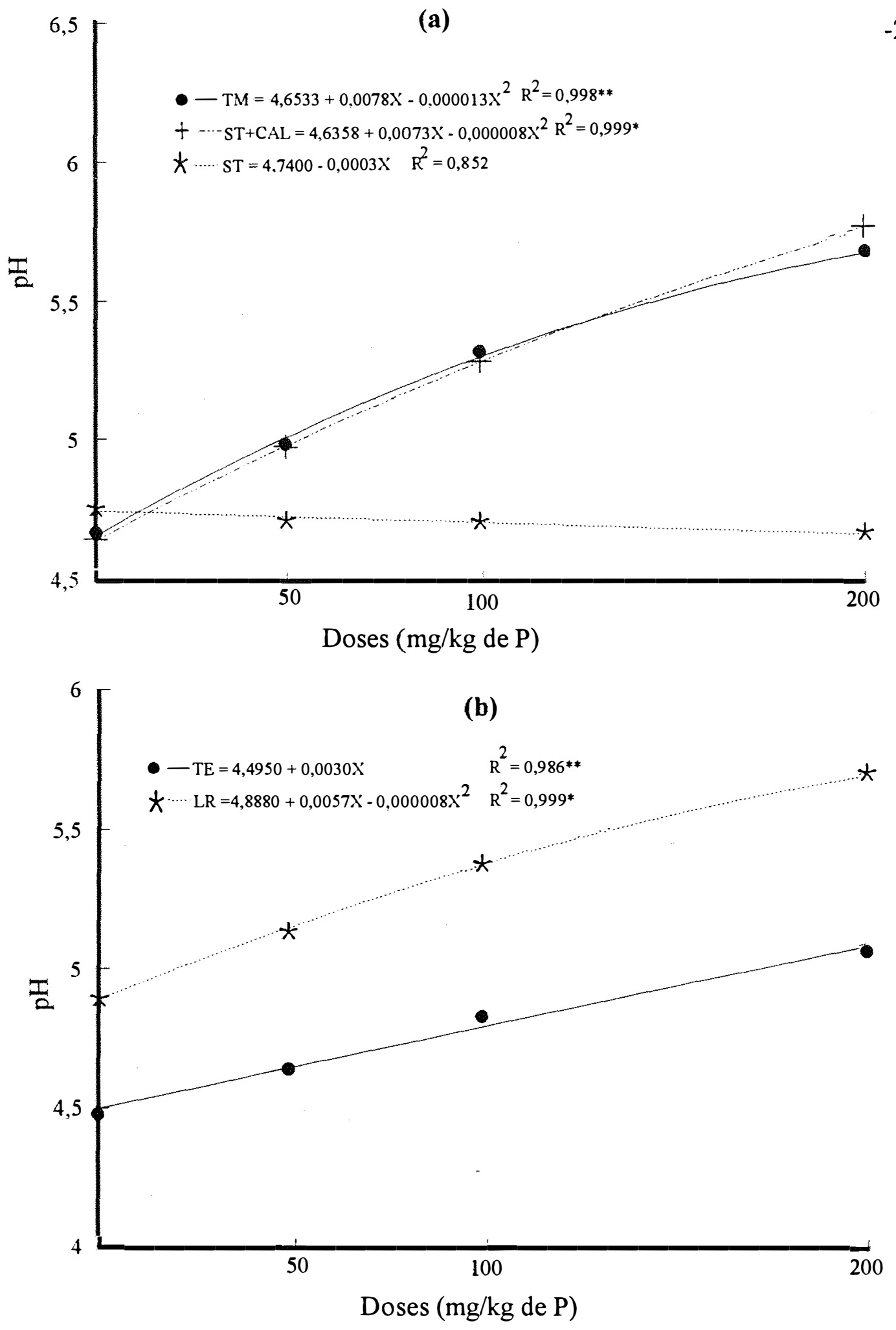

Figura 1. Valores de $\mathrm{pH}$ em $\mathrm{CaCl}_{2}$ (a) de amostras de solo tratadas com termofosfato magnesiano $(\mathrm{TM})$, superfosfato triplo + calcário $(\mathrm{ST}+\mathrm{CAL})$ e superfosfato triplo (ST) em diferentes doses de fósforo (médias de dois solos) e (b) de amostras de Terra Roxa Estruturada (TE) e Latossolo Roxo (LR), tratadas com diferentes doses de fósforo (médias de três fontes de fósforo). 
A semelhança entre os efeitos do TM e do ST +CAL sobre o $\mathrm{pH}$ em $\mathrm{CaCl}_{2}$ revela um fato importante: a quantidade de corretivo adicionada ao superfosfato triplo, estimada pela curva de neutralização, conferiu à mistura $S T+C A L$ poder de neutralização semelhante ao do termofosfato estudado, conforme se pretendia.

Tanto no TE quanto no LR, as fontes de fósforo TM e ST + CAL elevaram igualmente o $\mathrm{pH}$ em $\mathrm{CaCl}_{2}$ do solo, enquanto o ST manteve esse potencial a um valor mais baixo (Tabela 6).

Tabela 6 - Valores de pH em $\mathrm{CaCl}_{2}$ de amostras de Terra Roxa Estruturada (TE) e Latossolo Roxo (LR) tratadas com diferentes fontes de fósforo (média de quatro repetições e de quatro doses de fósforo: $0,50,100$ e $200 \mathrm{mg} / \mathrm{kg} \mathrm{de} \mathrm{P})^{1}$

\begin{tabular}{lccc}
\hline \hline & \multicolumn{3}{c}{ Fontes de fósforo ${ }^{2}$} \\
\cline { 2 - 4 } Solo & TM & ST +CAL & ST \\
\hline & & & \\
TE & $4,85 \mathrm{~A}$ & $4,91 \mathrm{~A}$ & $4,51 \mathrm{~B}$ \\
$\mathrm{LR}$ & $5,49 \mathrm{~A}$ & $5,43 \mathrm{~A}$ & $4,93 \mathrm{~B}$ \\
\hline \hline
\end{tabular}

(1) Dentro de cada solo, médias seguidas por letras iguais não diferem entre si pelo teste de Tukey ao nível de $5 \%$ de probabilidade.

${ }^{(2)} \mathrm{TM}$, termofosfato magnesiano; ST, superfosfato triplo; $\mathrm{CAL}$, mistura de $\mathrm{CaCO}_{3}$ e $\mathrm{MgCO}_{3}$ na relação 4:1.

A elevação do $\mathrm{pH}$ em $\mathrm{CaCl}_{2}$ provocada pela adição das fontes $\mathrm{TM}$ e $\mathrm{ST}+\mathrm{CAL}$, já esperada, deve-se à presença de silicato e carbonato nesses respectivos materiais. Os efeitos do TM no pH confirmam que esse adubo possui acentuado poder corretivo da acidez do solo, possibilitando redução nas necessidades de calcário. Essa capacidade neutralizante deve-se à presença do ânion silicato, na forma de silicato de cálcio, $\mathrm{CaSiO}_{3}$. 
Segundo MALAVOLTA (1985), a dissociação do $\mathrm{CaSiO}_{3}$ produz íons $\mathrm{Ca}^{2+}$ e $\mathrm{SiO}_{3}{ }^{2-} ;$ o $\mathrm{Ca}^{2+}$, por sua vez, desloca o $\mathrm{Al}^{3+}$ do complexo, enquanto o $\mathrm{SiO}_{3}^{-2}$ neutraliza os íons $\mathrm{H}^{+}$ presentes na solução do solo e converte-se em $\mathrm{H}_{2} \mathrm{SiO}_{3}$.

Para a porcentagem de saturação por bases (V) houve efeito significativo dos três fatores e da interação tripla (Tabela 3). Os valores de saturação por bases ocorridos no TE foram quase sempre superiores aos obtidos no LR; o fato da variação do valor $\mathrm{V}$ entre as doses 0 e 200 (média dos tratamentos com TM e ST +CAL, nos quais a variação foi significativa) nas amostras de LR $(31,50 \%$ a $72,88 \%)$ ter sido maior que a verificada no TE $(49,88 \%$ a $73,88 \%)$ constitui mais uma indicação, além daquela já mencionada com base no pH, de que o poder tampão desse último solo é maior que o do LR (Tabela 7).

Os efeitos das fontes de fósforo sobre a saturação por bases foram muito semelhantes aos verificados sobre o $\mathrm{pH} \mathrm{em} \mathrm{CaCl}_{2}$ : as fontes $\mathrm{TM}$ e $\mathrm{ST}+\mathrm{CAL}$ resultaram valores $\mathrm{V}$ sempre maiores que o $\mathrm{ST}$, em todas as doses aplicadas e em ambos os solos (Tabela 8). A semelhança entre os efeitos ocorridos no $\mathrm{pH}$ e no valor $\mathrm{V}$ provavelmente se deve à existência de forte correlação entre essas variáveis (CATANI \& GALLO, 1955; QUAGGIO, 1983; e YASUDA, 1989). De fato, um estudo de correlação linear realizado neste trabalho, mostrou coeficientes de correlação iguais a 0,95 e 0,98 para os solos TE e LR, respectivamente, ambos altamente significativos.

As regressões mostraram que o TM elevou a saturação por bases de $49,6 \%$ para até $73,9 \%$ e de $31,8 \%$ para até $74,1 \%$, respectivamente para o TE e LR (Figura 2). O ST + CAL, por sua vez, aumentou a saturação de $50,0 \%$ para até $73,8 \%$ e de $33,6 \%$ para até $72,3 \%$ para os respectivos solos, enquanto o ST não causou variação significativa desse parâmetro.

Os efeitos do termofosfato sobre o $\mathrm{pH} \mathrm{em} \mathrm{CaCl}_{2}$ e saturação por bases, obtidos neste estudo, estão em perfeita concordância com os relatados na literatura. Dados de MELLO et al. (1981) mostram o efeito do termofosfato em elevar o $\mathrm{pH}$ do solo, enquanto os da EMBRAPA (1982) revelam diminuição na quantidade de $\mathrm{Al}$ trocável e aumento nos 
teores de Ca e Mg. YASUDA (1989) verificou que o fosfato com maior teor de sílica, denominado comercialmente de "Yoosirin", proporcionou valores de $\mathrm{V}$ estatisticamente mais altos que os obtidos com o ST. O mesmo autor (YASUDA, 1989), estudando o comportamento de fosfatos silicatados em solo de cerrado, também verificou que o "Yoosirin" elevou o pH em água do solo de 4,40 para 6,05 em apenas 15 dias, assim como também aumentou os teores de $\mathrm{Ca}+\mathrm{Mg}$ trocáveis e a saturação por bases.

Tabela 7 - Saturação por bases (V) de amostras de Terra Roxa Estruturada (TE) e Latossolo Roxo (LR) tratadas com diferentes doses de fósforo, para cada fonte fosfatada (média de quatro repetições) ${ }^{(1)}$

\begin{tabular}{|c|c|c|c|c|c|}
\hline \multirow[b]{2}{*}{ Fonte $^{(2)}$} & \multirow[b]{2}{*}{ Solo } & \multicolumn{4}{|c|}{ Dose de fósforo $(\mathrm{mg} / \mathrm{kg}$ de $\mathrm{P})$} \\
\hline & & 0 & 50 & 100 & 200 \\
\hline & & & & & \\
\hline \multirow[t]{2}{*}{ TM } & TE & $49,50 \mathrm{a}$ & $60,00 \mathrm{a}$ & $66,50 \mathrm{a}$ & $74,00 \mathrm{a}$ \\
\hline & LR & $31,50 \mathrm{~b}$ & $49,50 \mathrm{~b}$ & $60,75 \mathrm{~b}$ & $74,25 \mathrm{a}$ \\
\hline \multirow[t]{2}{*}{$\mathrm{ST}+\mathrm{CAL}$} & $\mathrm{TE}$ & 50,25 a & 58,50 a & $66,75 \mathrm{a}$ & $73,75 \mathrm{a}$ \\
\hline & LR & $31,50 \mathrm{~b}$ & $45,75 b$ & $53,25 \mathrm{~b}$ & $71,50 \mathrm{a}$ \\
\hline \multirow[t]{2}{*}{ ST } & $\mathrm{TE}$ & 48,75 a & $51,25 \mathrm{a}$ & $49,00 \mathrm{a}$ & $51,75 \mathrm{a}$ \\
\hline & LR & $34,75 \mathrm{~b}$ & $33,75 \mathrm{~b}$ & $34,25 \mathrm{~b}$ & $36,75 \mathrm{~b}$ \\
\hline
\end{tabular}

(1) Dentro de cada fonte e de cada dose, médias seguidas por letras iguais não diferem entre si pelo teste de Tukey ao nivel de $5 \%$ de probabilidade.

${ }^{(2)} \mathrm{TM}$, termofosfato magnesiano; ST, superfosfato triplo; $\mathrm{CAL}$, mistura de $\mathrm{CaCO}_{3}$ e $\mathrm{MgCO}_{3}$ na relação 4:1. 
Tabela 8 - Saturação por bases (V) de amostras de terra tratadas com diferentes doses e fontes de fósforo, para cada solo (Terra Roxa Estruturada, TE; e Latossolo Roxo, LR (média de quatro repetições) ${ }^{(1)}$

\begin{tabular}{llcccc}
\hline & & \multicolumn{4}{c}{ Dose de fósforo $(\mathrm{mg} / \mathrm{kg}$ de P) } \\
\cline { 3 - 6 } Solo & Fonte $^{(2)}$ & 0 & 50 & 100 & 200 \\
\hline \multirow{2}{*}{ TE } & & & \multicolumn{3}{c}{$\%$} \\
& TM & $49,50 \mathrm{aD}$ & $60,00 \mathrm{aC}$ & $66,50 \mathrm{aB}$ & $74,00 \mathrm{aA}$ \\
& ST+CAL & $50,25 \mathrm{aD}$ & $58,50 \mathrm{aC}$ & $66,75 \mathrm{aB}$ & $73,75 \mathrm{aA}$ \\
& ST & $48,75 \mathrm{aA}$ & $51,25 \mathrm{bA}$ & $49,00 \mathrm{bA}$ & $51,75 \mathrm{bA}$ \\
& & & & & \\
LR & TM & $31,50 \mathrm{aD}$ & $49,50 \mathrm{aC}$ & $66,75 \mathrm{aB}$ & $74,25 \mathrm{aA}$ \\
& ST+CAL & $31,50 \mathrm{aD}$ & $45,75 \mathrm{aC}$ & $53,25 \mathrm{bB}$ & $71,50 \mathrm{aA}$ \\
& ST & $34,75 \mathrm{aA}$ & $33,75 \mathrm{bA}$ & $34,25 \mathrm{cA}$ & $36,75 \mathrm{bA}$ \\
\hline \hline
\end{tabular}

(1) Dentro de cada solo, médias seguidas por letras iguais, minúsculas dentro de cada dose e maíusculas dentro de cada fonte, não diferem entre si pelo teste de Tukey ao nível de $5 \%$ de probabilidade.

${ }^{2} \mathrm{TM}$, termofosfato magnesiano; ST, superfosfato triplo; $\mathrm{CAL}$, mistura de $\mathrm{CaCO}_{3}$ e $\mathrm{MgCO}_{3}$ na relação 4:1.

MORELLI et al. (1991), em experimento de fosfatagem conduzido em Areias Quartzosas com o objetivo de avaliar os efeitos do termofosfato aplicado a lanço e no sulco sobre as propriedades químicas do solo e a produtividade da cana-de-açúcar, verificaram que o termofosfato aumentou os níveis de cálcio e magnésio e a saturação por bases nas duas camadas de solo analisadas $(0-20 \mathrm{~cm}$ e $20-40 \mathrm{~cm})$, e que o $\mathrm{pH}$ da superfície do solo se elevou de 5,0 para 6,1 quando o fertilizante foi aplicado à lanço, na dose de $400 \mathrm{~kg} / \mathrm{ha}$ de $\mathrm{P}_{2} \mathrm{O}_{5}$. 

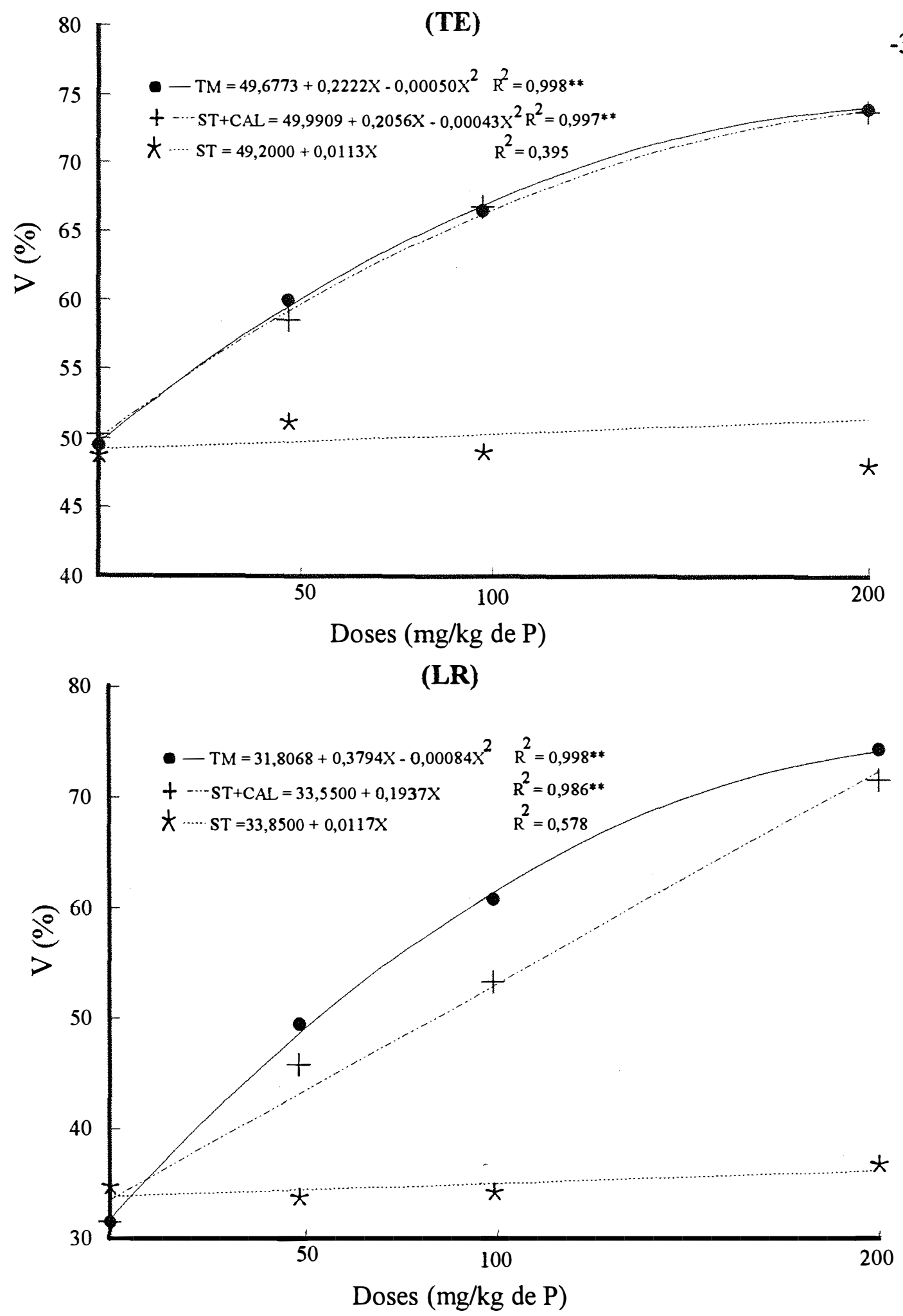

Figura 2. Porcentagem de saturação por bases $(\mathrm{V} \%)$, de amostras de Terra Roxa Estruturada (TE) e Latossolo Roxo (LR) tratadas com termofosfato magnesiano (TM), superfosfato triplo + calcário $(\mathrm{ST}+\mathrm{CAL})$ e superfosfato triplo (ST) em diferentes doses de fósforo. 


\subsubsection{Fósforo Extraído pelo Método da Resina}

Houve efeito significativo dos três fatores estudados e de duas interações duplas (solos $\mathrm{x}$ doses e fontes $\mathrm{x}$ doses) sobre os teores de P-resina (Tabela 3); o efeito da interação tripla não foi significativo. Nas amostras tratadas com 100 e $200 \mathrm{mg} / \mathrm{kg}$ de $\mathrm{P}$, e para a média das fontes, os teores de P-resina encontrados no LR $\left(42,67\right.$ e $101,58 \mu \mathrm{g} / \mathrm{cm}^{3}$ de $P$ ) foram significativamente superiores aos obtidos no TE $\left(35,92\right.$ e 70,67 $\left.\mu \mathrm{g} / \mathrm{cm}^{3} \mathrm{de} P\right)$, ocorrendo o inverso para a dose 0 (Tabela 9). Esse fato indica, como será discutido no item 4.1.4, ter havido maior fixação de fósforo no TE do que no LR, o que poderia ser explicado pelo fato de o TE possuir mais alumínio trocável que o LR, e de ser mais ácido (Tabela 2). Segundo KAMPRATH (1977), VOLKWEISS \& RAIJ (1977) e BRADY (1989), a fixação de P no solo é grandemente estimulada pela presença de compostos de $\mathrm{Al}$ e $\mathrm{Fe}$ no solo, de íons de $\mathrm{Al}$ e $\mathrm{Fe}$ trocáveis ou na solução, e de baixos valores de $\mathrm{pH}$.

Tabela 9 - Teores de fósforo extraído pelo método da resina, de amostras de Terra Roxa Estruturada (TE) e Latossolo Roxo (LR) tratadas com diferentes doses de fósforo (média de quatro repetições e de rês fontes fosfatadas: termofosfato magnesiano, superfosfato triplo + calcário e superfosfato triplo) ${ }^{(1)}$

\begin{tabular}{lcccc}
\hline \hline & \multicolumn{4}{c}{ Dose de fósforo $(\mathrm{mg} / \mathrm{kg}$ de $\mathrm{P})$} \\
\cline { 2 - 5 } Solo & 0 & 50 & 100 & 200 \\
\hline & & \multicolumn{4}{c}{$\mu \mathrm{g} / \mathrm{cm}^{3} \mathrm{de} \mathrm{P}$} \\
$\mathrm{TE}$ & $10,25 \mathrm{aD}$ & $21,50 \mathrm{aC}$ & $35,92 \mathrm{bB}$ & $70,67 \mathrm{bA}$ \\
& & & & \\
$\mathrm{LR}$ & $3,00 \mathrm{bD}$ & $17,50 \mathrm{aC}$ & $42,67 \mathrm{aB}$ & $101,58 \mathrm{aA}$ \\
\hline \hline
\end{tabular}

${ }^{(1)}$ Médias seguidas por letras iguais, minúsculas dentro de cada dose e maíusculas dentro de cada solo, não diferem entre si pelo teste de Tukey ao nível de $5 \%$ de probabilidade. 
$\mathrm{Na}$ dose $50 \mathrm{mg} / \mathrm{kg}$ de $\mathrm{P}$, todas as fontes de $\mathrm{P}$ resultaram teores de P-resina semelhantes, mas nas doses maiores o TM e o ST + CAL conferiram ao solo teores mais elevados que o ST (Tabela 10). Esse efeito também pode ser avaliado através das regressões: embora tenha havido aumentos significativos dos teores de P-resina com as doses aplicadas de todas as fontes, os aumentos foram maiores para o TM e o ST +CAL do que para o ST (Figura 3a).

Conforme mostra a Figura 3b, os incrementos no teor de P-resina observados no LR (de 2,4 para 101,8 $\mu \mathrm{g} / \mathrm{cm}^{3}$ de P) foram maiores que os ocorridos no TE (de 10,2 para $70,7 \mu \mathrm{g} / \mathrm{cm}^{3}$ de P), o que confirma a observação feita anteriormente de que o TE possui maior capacidade de fixação de fosfato que o LR.

Tabela 10 - Teores de fósforo extraído pelo método da resina, de amostras de solo tratadas com diferentes doses e fontes de fósforo (médias de quatro repetições e de dois solos, Terra Roxa Estruturada e Latossolo Roxo) ${ }^{(1)}$

\begin{tabular}{lcccr}
\hline \hline \multirow{2}{*}{ Fonte $^{(2)}$} & \multicolumn{5}{c}{ Dose de fósforo $(\mathrm{mg} / \mathrm{kg}$ de P) } \\
\cline { 2 - 5 } & 0 & 50 & 100 & 200 \\
\hline & \multicolumn{4}{c}{$\mu \mathrm{g} / \mathrm{cm}^{3} \mathrm{de} \mathrm{P}$} \\
TM & $7,38 \mathrm{aD}$ & $20,25 \mathrm{aC}$ & $41,50 \mathrm{aB}$ & $95,00 \mathrm{aA}$ \\
ST+CAL & $6,88 \mathrm{aD}$ & $19,63 \mathrm{aC}$ & $45,00 \mathrm{aB}$ & $95,38 \mathrm{aA}$ \\
ST & $5,63 \mathrm{aD}$ & $18,63 \mathrm{aC}$ & $31,38 \mathrm{bB}$ & $68,00 \mathrm{bA}$ \\
\hline \hline
\end{tabular}

${ }^{(1)}$ Médias seguidas por letras iguais, minúsculas dentro de cada dose e maíusculas dentro de cada fonte, não diferem entre si pelo teste de Tukey ao nível de $5 \%$ de probabilidade.

${ }^{(2)} \mathrm{TM}$, termofosfato magnesiano; ST, superfosfato triplo; $\mathrm{CAL}$, mistura de $\mathrm{CaCO}_{3}$ e $\mathrm{MgCO}_{3}$ na relação 4:1. 
Os efeitos das fontes TM e ST + CAL sobre o teor de P-resina foram semelhantes aos verificados sobre os valores de $\mathrm{pH}$ em $\mathrm{CaCl}_{2}$ (Figura 1), pois o TM e o $\mathrm{ST}+\mathrm{CAL}$ aumentaram igualmente o $\mathrm{pH}$, enquanto o $\mathrm{ST}$ não alterou essa característica. Essas observações concordam com as obtidas por YASUDA (1989), o qual verificou, em solos de cerrado, que o fosfato denominado comercialmente de "Yoosirin", com alto teor de sílica, proporcionou maiores teores de fósforo "disponível" e valores mais altos de $\mathrm{pH}$ no solo que o superfosfato triplo.

Considerando-se que o $\mathrm{TM}$ e o $\mathrm{ST}+\mathrm{CAL}$ produziram efeitos semelhantes sobre o teor de P-resina e sobre o $\mathrm{pH}$ em $\mathrm{CaCl}_{2}$ do solo, é possível inferir que o melhor desempenho dessas fontes, em relação ao $\mathrm{ST}$, se deva à correção do $\mathrm{pH}$ proporcionada por elas. Segundo MALAVOLTA (1976), a elevação do pH pelo uso de calcário em solo ácido aumenta a solubilidade dos fosfatos de ferro e alumínio e, conseqüentemente, a possibilidade de se formarem fosfatos de cálcio mais solúveis; além disso, há o efeito favorável da competição entre os íons $\mathrm{OH}^{-}$resultantes da calagem e os íons $\mathrm{H}_{2} \mathrm{PO}_{4}^{-}$pelas posições de adsorção no colóide. Ainda a este respeito, MALAVOLTA (1985) comenta que os adubos fosfatados que tendem a elevar o $\mathrm{pH}$ do solo devem produzir efeitos parecidos com os da calagem. 

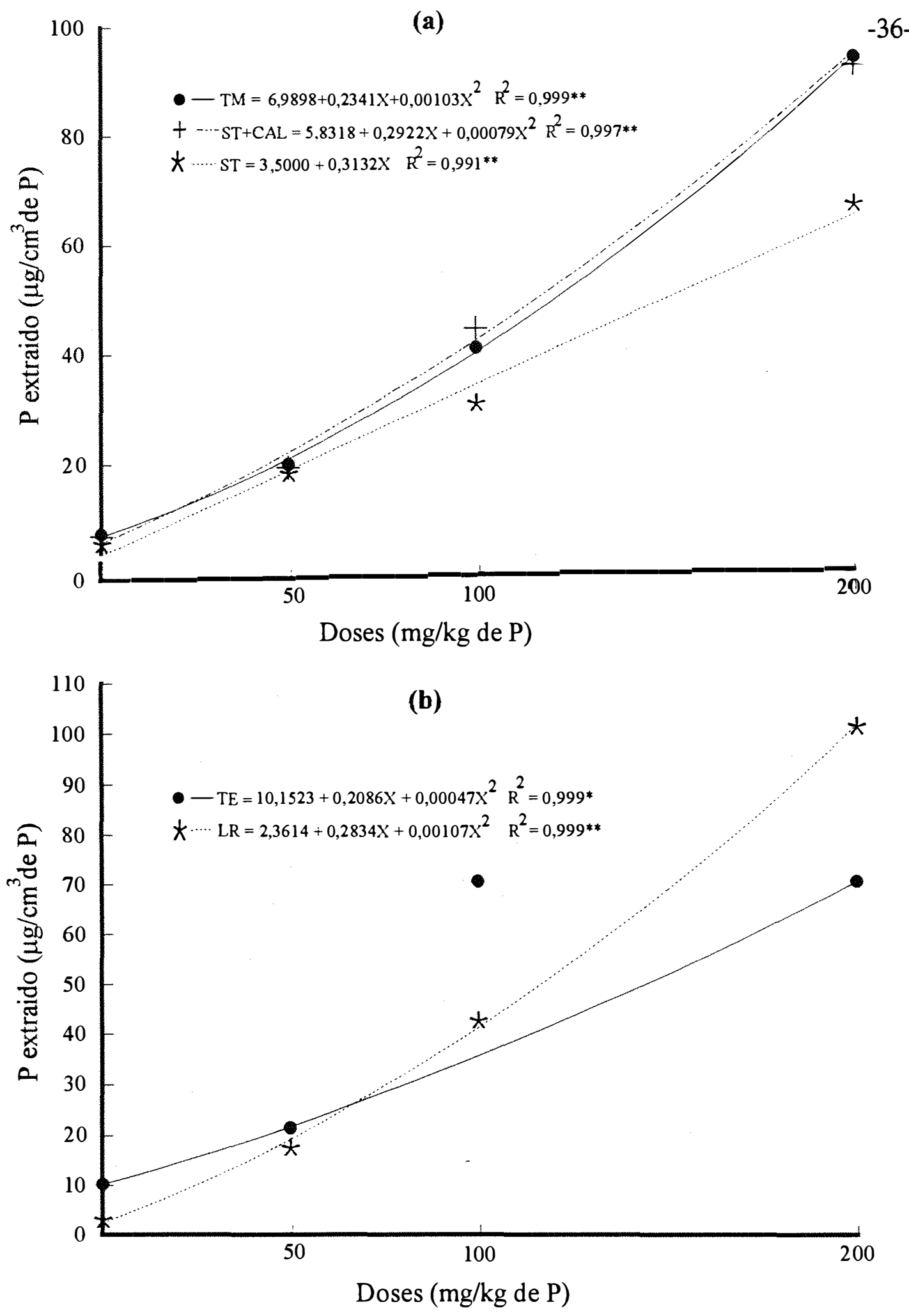

Figura 3. Teores de fósforo extraídos pela resina (a) de amostras de solo tratadas com termofosfato magnesiano (TM), superfosfato triplo + calcário (ST+CAL) e superfosfato triplo (ST) em diferentes doses de fósforo (médias de dois solos) e (b) de amostras de Terra Roxa Estruturada (TE) e Latossolo Roxo (LR), tratadas com diferentes doses de fósforo (médias de três fontes de fósforo). 


\subsubsection{Fósforo Extraído pelo Método de Bray-1}

Para o fósforo extraído pelo método Bray-1 houve efeito significativo dos três fatores estudados e da interação tripla (Tabela 3). Nas amostras tratadas com TM e ST nas doses de 100 e $200 \mathrm{mg} / \mathrm{kg}$ de $\mathrm{P}$, os teores de P-Bray encontrados no LR foram significativamente superiores aos obtidos no TE, ocorrendo o inverso dentro da dose 0 (Tabela 11). Esse comportamento foi devido à maior fixação de fósforo no TE do que no LR, conforme também indicaram os resultados de $\mathrm{P}$ extraído pela resina. Nas amostras tratadas com ST + CAL não houve diferenças significativas entre os solos quanto aos teores de fósforo extraídos pelo Bray-1.

No solo TE e na dose mais elevada o ST + CAL foi o material que conferiu o maior teor de fósforo $(33,38 \mu \mathrm{g} / \mathrm{g}$ de P), seguindo-se o ST $(26,87 \mu \mathrm{g} / \mathrm{g}$ de P) e o TM (24,64 $\mu \mathrm{g} / \mathrm{g}$ de P) (Tabela 12); nas doses menores a separação entre as fontes foi cada vez menos nítida. No solo LR as fontes diferiram entre si somente na dose $200 \mathrm{mg} / \mathrm{kg}$ de $\mathrm{P}$, quando os teores de P obtidos com a adição do ST + CAL $(34,50 \mu \mathrm{g} / \mathrm{g}$ de P) e do ST $(33,59 \mu \mathrm{g} / \mathrm{g}$ de $\mathrm{P})$ foram superiores ao encontrado com a aplicação do TM $(31,77 \mu \mathrm{g} / \mathrm{g}$ de P).

É possível que a menor discriminação entre as fontes de fósforo no LR seja resultado de um mascaramento da extração de fósforo do solo pelo extrator Bray-1. KAMPRATH \& WATSON (1980) indicam que a ação do extrator Bray-1 deve-se à acidez e à presença do ânion fluoreto: o $\mathrm{HCl}$ solubiliza as formas de fósforo mais facilmente solúveis e dissolve, mais fortemente, o P-Ca. A precipitação do cálcio pelos íons fluoreto permite que o $\mathrm{P}$ presente no solo como fosfato dicálcico seja extraído; além disso, o fluoreto presente no extrator em meio ácido complexa o ferro e o alumínio, liberando o fósforo ligado a esses metais. Esse fato pode ter contribuído para que o extrator Bray-1 tenha dissolvido uma proporção maior do fósforo ligado ao ferro, resultando menor discriminação entre as fontes aplicadas nesse solo. 
Segundo THOMAS \& PEASLEE (1973), o extrator Bray-1 não é recomendado para solos altamente intemperizados, com baixa CTC, mas para os que possuam quantidade razoável de P-Ca, cujo grau de intemperismo seja de moderado a alto e que possua uma CTC situada entre baixa e média; o solo LR, fortemente intemperizado $(\mathrm{Ki}=0,69$ ), certamente não possui essas características. Segundo KRAMPRATH \& WATSON (1980), o extrator de fósforo ideal seria aquele que não fosse influenciado pelas diferenças nas propriedades químicas e mineralógicas do solo.

Tabela 11 - Teores de fósforo extraído pelo método de Bray-1, de amostras de Terra Roxa Estruturada (TE) e Latossolo Roxo (LR) tratadas com diferentes doses de fósforo, para cada fonte fosfatada (média de quatro repenções) $)^{(1)}$

\begin{tabular}{|c|c|c|c|c|c|}
\hline \multirow[b]{2}{*}{ Fonte $^{(2)}$} & \multirow[b]{2}{*}{ Solo } & \multicolumn{4}{|c|}{ Dose de fósforo (mg/kg de P) } \\
\hline & & 0 & 50 & 100 & 200 \\
\hline & & & $\mu \mathrm{g} /$ & & \\
\hline \multirow[t]{2}{*}{ TM } & $\mathrm{TE}$ & $2,87 \mathrm{a}$ & $8,90 \mathrm{a}$ & $12,52 \mathrm{~b}$ & $24,64 b$ \\
\hline & LR & $1,28 \mathrm{~b}$ & $7,12 b$ & $14,90 \mathrm{a}$ & $31,77 \mathrm{a}$ \\
\hline \multirow[t]{2}{*}{$\mathrm{ST}+\mathrm{CAL}$} & $\mathrm{TE}$ & $2,88 \mathrm{a}$ & $9,32 \mathrm{a}$ & $15,15 \mathrm{a}$ & $33,38 \mathrm{a}$ \\
\hline & LR & $1,34 \mathrm{~b}$ & $8,76 \mathrm{a}$ & $15,24 \mathrm{a}$ & $34,50 \mathrm{a}$ \\
\hline \multirow[t]{2}{*}{ ST } & $\mathrm{TE}$ & $3,02 \mathrm{a}$ & $7,64 \mathrm{a}$ & $12,70 \mathrm{~b}$ & $26,87 \mathrm{~b}$ \\
\hline & LR & $1,30 \mathrm{~b}$ & $8,62 \mathrm{a}$ & $15,59 \mathrm{a}$ & $33,59 \mathrm{a}$ \\
\hline
\end{tabular}

(1) Dentro de cada fonte e de cada dose, médias seguidas por letras iguais não diferem entre si pelo teste de Tukey ao nível de $5 \%$ de probabilidade.

${ }^{(2)} \mathrm{TM}$, termofosfato magnesiano; ST, superfosfato triplo; $\mathrm{CAL}$, mistura de $\mathrm{CaCO}_{3}$ e $\mathrm{MgCO}_{3}$ na relação 4:1. 
Tabela 12 - Teores de fósforo extraído pelo método de Bray-1, de amostras de terra tratadas com diferentes doses e fontes de fósforo, para cada solo (Terra Roxa Estruturada, TE; e Latossolo Roxo, LR) (média de quatro repetições) ${ }^{(1)}$

\begin{tabular}{|c|c|c|c|c|c|}
\hline \multirow[b]{2}{*}{ Solo } & \multirow[b]{2}{*}{ Fonte $^{(2)}$} & \multicolumn{4}{|c|}{ Dose de fósforo (mg/kg de $\mathrm{P}$ ) } \\
\hline & & 0 & 50 & 100 & 200 \\
\hline & & & & & \\
\hline \multirow[t]{3}{*}{$\mathrm{TE}$} & TM & $2,87 \mathrm{aD}$ & $8,90 \mathrm{abC}$ & $12,52 \mathrm{bB}$ & $24,64 \mathrm{cA}$ \\
\hline & $\mathrm{ST}+\mathrm{CAL}$ & $2,88 \mathrm{aD}$ & $9,32 \mathrm{aC}$ & $15,15 \mathrm{aB}$ & $33,38 \mathrm{aA}$ \\
\hline & ST & $3,02 \mathrm{aD}$ & $7,64 \mathrm{bC}$ & $12,70 \mathrm{bB}$ & $26,87 \mathrm{bA}$ \\
\hline \multirow[t]{3}{*}{ LR } & TM & $1,28 \mathrm{aD}$ & $7,12 \mathrm{aC}$ & $14,90 \mathrm{aB}$ & $31,77 \mathrm{bA}$ \\
\hline & $\mathrm{ST}+\mathrm{CAL}$ & $1,34 \mathrm{aD}$ & $8,76 \mathrm{aC}$ & $15,24 \mathrm{aB}$ & $34,50 \mathrm{aA}$ \\
\hline & ST & $1,30 \mathrm{aD}$ & $8,62 \mathrm{aC}$ & $15,59 \mathrm{aB}$ & $33,59 \mathrm{aA}$ \\
\hline
\end{tabular}

\footnotetext{
(1)Dentro de cada solo, médias seguidas por letras iguais, minúsculas dentro de cada dose e maíusculas dentro de cada fonte, não diferem entre si pelo teste de Tukey ao nível de $5 \%$ de probabilidade.

${ }^{2} \mathrm{TM}$, termofosfato magnesiano; ST, superfosfato triplo; $\mathrm{CAL}$, mistura de $\mathrm{CaCO}_{3}$ e $\mathrm{MgCO}_{3}$ na relação 4:1.
}

Comparando-se os resultados obtidos com os dois extratores entre si verifica-se que, quando se utilizou o método da resina (Tabela 10), o TM e o ST +CAL conferiram maiores teores de fósforo no solo que a fonte ST, mas quando o método de Bray-1 foi empregado (Tabela 12), a relação entre as fontes se alterou e se mostrou dependente da dose e do solo em que foi aplicada. Baseando-se nos resultados de produção de matéria seca e quantidade de fósforo acumulada na parte aérea das plantas, a serem apresentados nos itens 4.2.1 e 4.2.5 (Tabelas 17 e 26), constata-se que o método da resina foi superior ao do Bray-1 em avaliar o efeito das fontes sobre o teor de fósforo do solo. RAIJ (1978), RAIJ et al. (1982) e GRANDE et al. (1986) verificaram, de fato, que a resina trocadora 
de ânions fornece melhores correlações com a resposta das culturas à adubação fosfatada que outros extratores.

As regressões polinomiais mostraram que as aplicações de fósforo refletiram em incrementos significativos dos teores de P-Bray com a quantidade aplicada de cada fonte de adubo, para ambos os solos (Figura 4); entretanto, conforme já comentado, esse método de extração avaliou o efeito das fontes de fósforo de forma diferente da obtida com a resina (Figura 3a), fato que se constata pela alteração na posição relativa das curvas correspondentes a cada fonte. 

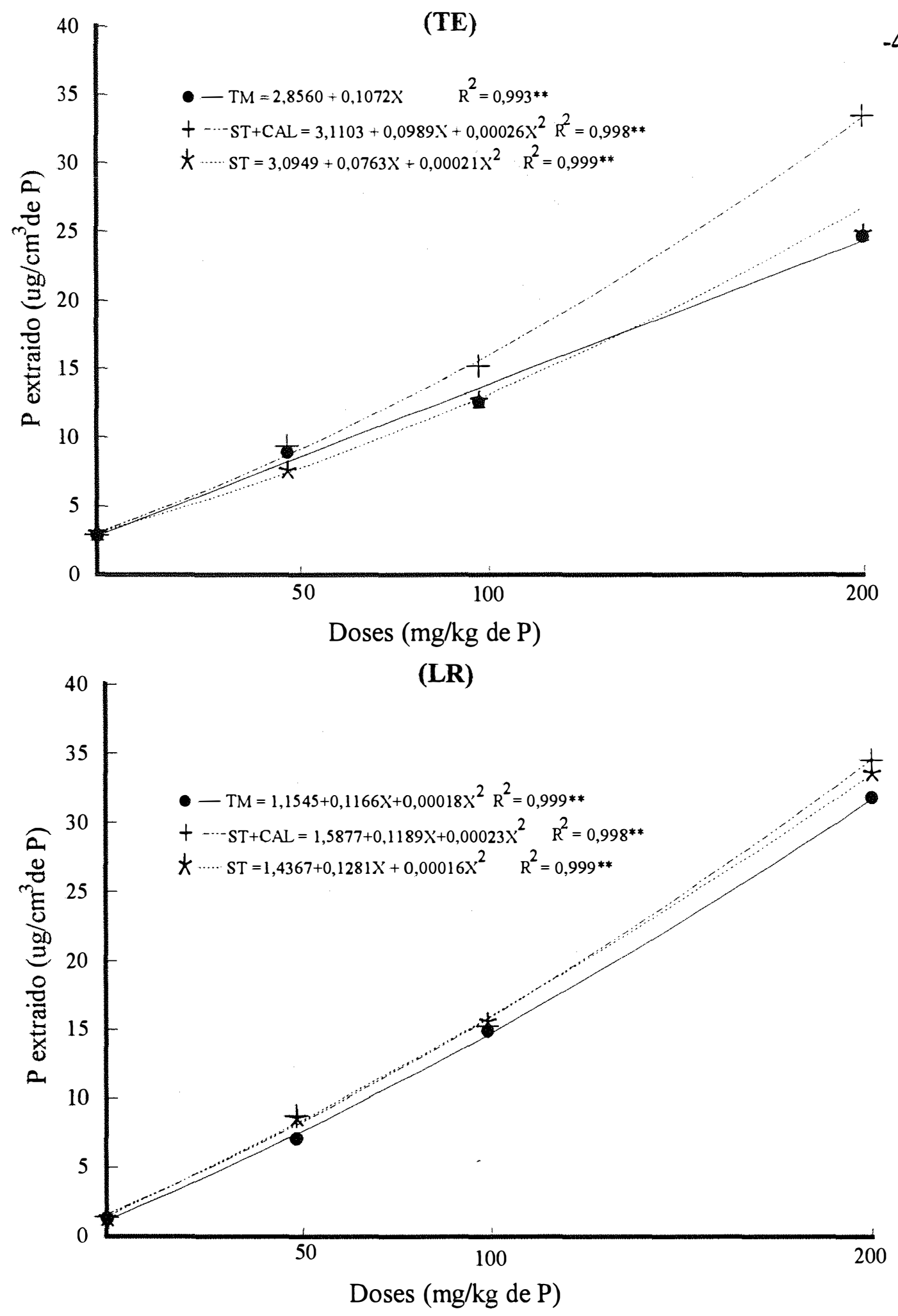

Figura 4. Teores de fósforo extraídos pelo método Bray-1, de amostras de Terra Roxa Estruturada (TE) e Latossolo Roxo (LR), tratadas com termofosfato magnesiano $(\mathrm{TM})$, superfosfato triplo + calcário $(\mathrm{ST}+\mathrm{CAL})$ e superfosfato triplo (ST) em diferentes doses de fósforo. 


\subsubsection{Silica Solúvel ${ }^{1}$}

Para a sílica solúvel houve efeito significativo dos três fatores estudados e da interação tripla (Tabela 3). As análises efetuadas nas amostras não tratadas com fósforo mostram que o solo TE continha originalmente mais sílica solúvel que o LR (Tabela 13). Esse fato talvez seja explicado pela maior quantidade de minerais silicatados presentes no TE, cujo teor de $\mathrm{SiO}_{2}(14,70 \%)$ é maior que o do $\mathrm{LR}$ (6,74\%) (Tabela 2). Conforme comentado no item 3.1, os índices $\mathrm{Ki} \mathrm{e} \mathrm{Kr}$ indicam que na composição mineralógica da fração argila do TE devem predominar minerais intemperizáveis, como a caulinita, enquanto no LR prevalecem minerais altamente intemperizados, como a gibsita. Nas amostras tratadas com as fontes de fósforo os teores de sílica solúvel continuaram sendo maiores no TE que no LR (Tabela 13).

Os teores de sílica solúvel dos solos estudados, mesmo nas amostras tratadas com o TM, estão dentro das faixas de variação encontradas por RAIJ \& CAMARGO (1973) para 44 perfís de solos do Estado de São Paulo; utilizando o mesmo extrator empregado no presente trabalho, esses autores encontraram, no horizonte superficial, teores variando de 29 a 92, de 13 a 35 e de 2,2 a $12 \mathrm{ppm}$ de $\mathrm{SiO}_{2}$ para os solos TE, LR e LE fase arenosa, respectivamente. Assim como neste estudo, RALJ \& CAMARGO (1973) verificaram que, para solos com teores semelhantes de argila, os teores de sílica foram maiores para os solos com horizonte B textural que para os com horizonte B latossólico. Observaram, ainda, que não houve relação entre os teores de sílica solúvel e o pH dos solos.

\footnotetext{
${ }^{1}$ Mais comurnente é feita referência à silica, $\mathrm{SiO}_{2}$, em vez de ao silício, Si.
} 
Tabela 13 - Teores de sílica solúvel de amostras de Terra Roxa Estruturada (TE) e Latossolo Roxo (LR) tratadas com diferentes doses de fósforo, para cada fonte fosfatada (média de quatro repetições) ${ }^{(1)}$

\begin{tabular}{lccccc}
\hline \hline & & \multicolumn{4}{c}{ Dose de fósforo $(\mathrm{mg} / \mathrm{kg}$ de P) } \\
\cline { 3 - 6 } Fonte ${ }^{(2)}$ & Solo & 0 & 50 & 100 & 200 \\
\hline \multirow{3}{*}{$\mathrm{TM}$} & & & \multicolumn{2}{c}{$\mu \mathrm{g} / \mathrm{g}$ de $\mathrm{SiO}_{2}$} & \\
& $\mathrm{TE}$ & $46,5 \mathrm{a}$ & $52,4 \mathrm{a}$ & $58,8 \mathrm{a}$ & $67,5 \mathrm{a}$ \\
& $\mathrm{LR}$ & $16,5 \mathrm{~b}$ & $24,7 \mathrm{~b}$ & $27,1 \mathrm{~b}$ & $32,1 \mathrm{~b}$ \\
$\mathrm{ST}+\mathrm{CAL}$ & $\mathrm{TE}$ & $46,0 \mathrm{a}$ & $45,3 \mathrm{a}$ & $44,9 \mathrm{a}$ & $44,6 \mathrm{a}$ \\
& $\mathrm{LR}$ & $16,5 \mathrm{~b}$ & $16,0 \mathrm{~b}$ & $15,2 \mathrm{~b}$ & $15,1 \mathrm{~b}$ \\
$\mathrm{ST}$ & $\mathrm{TE}$ & $47,0 \mathrm{a}$ & $47,5 \mathrm{a}$ & $47,6 \mathrm{a}$ & $47,9 \mathrm{a}$ \\
& $\mathrm{LR}$ & $16,7 \mathrm{~b}$ & $17,1 \mathrm{~b}$ & $17,3 \mathrm{~b}$ & $17,5 \mathrm{~b}$ \\
\hline \hline
\end{tabular}

(1) Dentro de cada fonte e de cada dose, médias seguidas por letras iguais não diferem entre si pelo teste de Tukey ao nivel de $5 \%$ de probabilidade.

${ }^{2} \mathrm{TM}$, termofosfato magnesiano; ST, superfosfato triplo; $\mathrm{CAL}$, mistura de $\mathrm{CaCO}_{3}$ e $\mathrm{MgCO}_{3}$ na relação 4:1.

Em ambos os solos e para todas as doses o TM foi a fonte que proporcionou os teores mais elevados de sílica solúvel (Tabela 14), já que era a única contendo expressiva proporção desse elemento: aproximadamente $25 \%$ de $\mathrm{SiO}_{2}$, dos quais mais de $90 \%$ solúveis em ácido cítrico. Dentre as demais fontes não portadoras de silício, o teor desse elemento no solo foi pouco maior quando se aplicou o ST do que quando se forneceu o ST +CAL, provavelmente porque o aumento do $\mathrm{pH}$ em $\mathrm{CaCl}_{2}$ (Figura 1), causado pela presença de calcário na fonte $\mathrm{ST}+\mathrm{CAL}$, tenha favorecido a adsorção do ânion silicato ao complexo coloidal do solo, diminuindo a quantidade de sílica extraída. Esses resultados confirmam as observações de outros autores. AYRES (1966) verificou que a calagem com carbonato de cálcio, diminuindo a concentração de silício na solução do solo, reduz a absorção desse elemento pela cana-de-açúcar. BECKWITH \& REEVE (1963) demonstraram, para solos lateríticos da Austrália apresentando valores de $\mathrm{pH}$ variando de 4,0 a 9,0, haver aumento do teor de sílica solúvel com a diminuição do $\mathrm{pH}$. 
Tabela 14 - Teores de sílica solúvel de amostras de Terra Roxa Estruturada (TE) e Latossolo Roxo (LR) tratadas com diferentes doses e fontes de fósforo (média de quatro repetições) $)^{(1)}$

\begin{tabular}{llcccr}
\hline \hline & & \multicolumn{4}{c}{ Dose de fósforo (mg/kg de P) } \\
\cline { 3 - 6 } Solo & Fonte $^{(2)}$ & 0 & 50 & 100 & 200 \\
\hline \multirow{3}{*}{ TE } & & & \multicolumn{4}{c}{$\mu \mathrm{g} /{\mathrm{g} \mathrm{de} \mathrm{SiO}_{2}}$} \\
& $\mathrm{TM}$ & $46,5 \mathrm{aD}$ & $52,4 \mathrm{aC}$ & $58,8 \mathrm{aB}$ & $67,5 \mathrm{aA}$ \\
& $\mathrm{ST}+\mathrm{CAL}$ & $46,0 \mathrm{aA}$ & $45,3 \mathrm{cA}$ & $44,9 \mathrm{cA}$ & $44,6 \mathrm{cA}$ \\
& $\mathrm{ST}$ & $47,0 \mathrm{aA}$ & $47,5 \mathrm{bA}$ & $47,6 \mathrm{bA}$ & $47,9 \mathrm{bA}$ \\
& & & & & \\
LR & $\mathrm{TM}$ & $16,5 \mathrm{aD}$ & $24,7 \mathrm{aC}$ & $27,1 \mathrm{aB}$ & $32,1 \mathrm{aA}$ \\
& $\mathrm{ST}+\mathrm{CAL}$ & $16,5 \mathrm{aA}$ & $16,0 \mathrm{bAB}$ & $15,2 \mathrm{cAB}$ & $15,1 \mathrm{cB}$ \\
& $\mathrm{ST}$ & $16,7 \mathrm{aA}$ & $17,1 \mathrm{bA}$ & $17,3 \mathrm{bA}$ & $17,5 \mathrm{bA}$ \\
\hline \hline
\end{tabular}

(1) Dentro de cada solo, médias seguidas por letras iguais, minúsculas dentro de cada dose e maíusculas dentro de cada fonte, não diferem entre si pelo teste de Tukey ao nível de $5 \%$ de probabilidade.

(2)TM, termofosfato magnesiano; ST, superfosfato triplo; $\mathrm{CAL}$, mistura de $\mathrm{CaCO}_{3}$ e $\mathrm{MgCO}_{3}$ na relação 4:1.

Alexander et al. ${ }^{1}$ e Okamoto et al. ${ }^{2}$, citados por BESOAIN (1985), indicaram que a solubilidade da sîlica (cristalina ou amorfa) não é afetada pelo pH quando este se encontra abaixo de 9,0, mas incrementa-se fortemente acima deste valor. Aparentemente, a rápida solubilidade acima do $\mathrm{pH} 9,0$ deve-se à ionização do ácido monossilícico:

$$
\mathrm{Si}(\mathrm{OH})_{4}+\mathrm{OH}^{-} \rightleftarrows \mathrm{Si}(\mathrm{OH})_{3} \mathrm{O}^{-}+\mathrm{H}_{2} \mathrm{O}
$$

${ }^{1}$ ALEXANDER, G.B.; HESTON, W.M \& ILER, R.K. The solubility of amorphous silica in water. Journal of Physical Chemistry, 58:453-455, 1954.

OKAMOTO, G.; OKURA, T. \& GETO, K. Properties of silica in water. Geochimic Cosmochim Acta, 12:123-132, 1957. 
Por outro lado, Bowden et al. ${ }^{1}$, citados por THENG (1980), verificaram que a adsorção de silicato $\left(\mathrm{H}_{3} \mathrm{SiO}_{4}\right)$ pela goetita aumenta com o incremento do $\mathrm{pH}$ para valores abaixo de 9,5 (valor da constante $\mathrm{pK}_{1}$ ), e que logo acima deste valor começam a dominar as forças eletrostáticas de repulsão, resultando decréscimo na adsorção de silicato com o aumento do pH. De acordo com MALAVOLTA (1980), a decomposição de minerais silicatados libera silício na solução do solo na forma de ácido monossilícico, $\mathrm{Si}(\mathrm{OH})_{4}$, desde que o pH esteja abaixo de 9,0. A concentração desse ácido em solução é governada pelo pH que, por sua vez, influencia sua adsorção aos óxidos de $\mathrm{Fe}$ e $\mathrm{Al}$; essa adsorção diminui abaixo e acima daquele valor de $\mathrm{pH}(\mathrm{pH} 9,0)$. Por esse motivo, a calagem, elevando o $\mathrm{pH}$ para 6,06,5 , diminui a disponibilidade de silício.

As regressões polinomiais mostraram que em ambos os solos, os efeitos de doses sobre os teores de sílica foram mais pronunciados quando se aplicou o TM, já que as demais fontes não continham silício (Figura 5). Pelas regressões, o ST+CAL causou ligeira redução no teor de sílica solúvel; essa redução, conforme já comentado, provavelmente tenha sido causada pelo aumento do $\mathrm{pH} \mathrm{em} \mathrm{CaCl}_{2} \mathrm{e}$, conseqüentemente, da adsorção do ânion silicato ao complexo coloidal do solo, reduzindo a quantidade de sílica extraída. Por outro lado, as aplicações de fósforo na forma de ST não aumentaram significativamente os teores de sílica solúvel de ambos os solos, provavelmente porque as doses aplicadas não foram suficientes para causar deslocamento do silício originalmente adsorvido ao colóide.

Da mesma forma que os teores de sílica solúvel das amostras tratadas com $\mathrm{ST}+\mathrm{CAL}$ foram menores que os daquelas que receberam somente ST, devido ao maior $\mathrm{pH}$ causado pela presença de carbonatos, era de se esperar que, com as doses crescentes de $\mathrm{ST}+\mathrm{CAL}$, as quais também resultaram valores crescentes de $\mathrm{pH}$, houvesse diminuição do teor de sílica solúvel; contudo, na Tabela 14 observa-se que esse teor apresentou pouca

'BOWDEN, J.W.; BOLLAND, M.D.A.; POSNER, A.M.; QUIRK, J.P. Generalised model for anion and cation adsorption at oxides surfaces. Nature Phys. Sci., 245:81-43, 1973. 


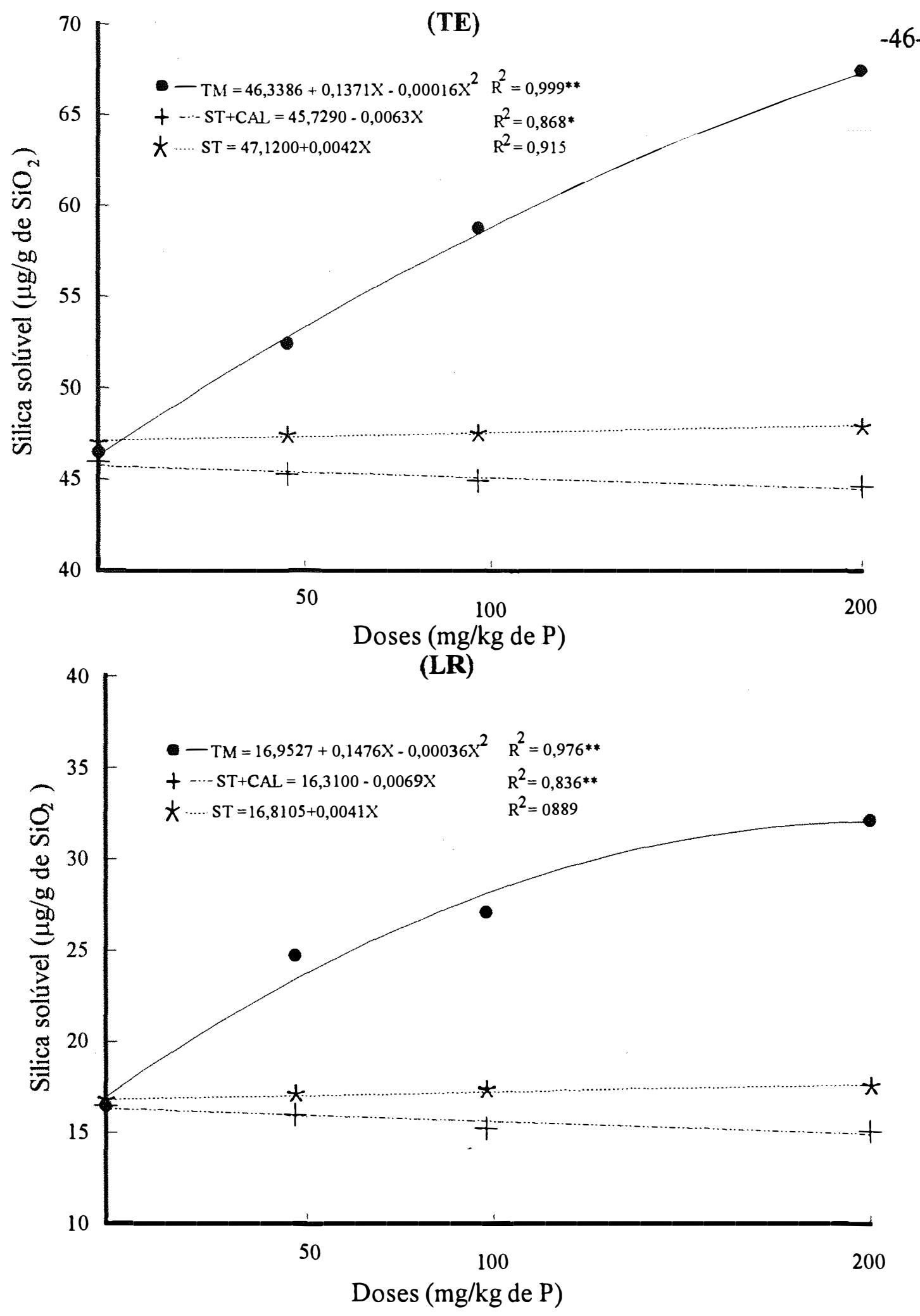

Figura 5. Teores de sílica solúvel, de amostras de Terra Roxa Estruturada (TE) e Latossolo Roxo (LR), tratadas com termofosfato magnesiano (TM), superfosfato triplo + calcário (ST+CAL) e superfosfato triplo (ST) em diferentes doses de fósforo. 
variação com o aumento da dose de ST +CAL, em ambos os solos. Considerando-se que neste caso tanto o $\mathrm{pH}$ em $\mathrm{CaCl}_{2}$ quanto o teor de fósforo no solo aumentaram, é possível que a adsorção de fosfato ao complexo coloidal do solo tenha aumentado a ponto de impedir a adsorção dos ânions silicato.

Os resultados apresentados na Tabela 14 mostram que, após a incubação das amostras de solo com o TM, ambos os ânions fosfato e silicato foram fixados pelo complexo coloidal do solo, pois as quantidades de fósforo e silício encontradas nas análises, nas respectivas doses, foram menores que as quantidades adicionadas $(50,100 \mathrm{e}$ $200 \mathrm{mg} / \mathrm{kg}$ de $\mathrm{P}$ e 157,314 e $628 \mathrm{mg} / \mathrm{kg}$ de $\mathrm{SiO}_{2}$ ). Os cálculos mostraram que, em média, as taxas de fixação de fósforo no solo TE foram de $77,5 \%, 74,3 \%$ e $69,8 \%$ e no $\mathrm{LR}$, de $71,0 \%, 60,3 \%$ e $50,7 \%$, respectivamente para as diferentes doses de $\mathrm{P}$ aplicadas, revelando que o TE fixa mais fósforo que o LR. Para o silício, as taxas de fixação no solo TE foram de $96,2 \%, 96,1 \%$ e $96,7 \%$ e no $L R$, de $94,7 \%, 96,6 \%$ e $97,5 \%$, respectivamente para as diferentes doses de $\mathrm{SiO}_{2}$ aplicadas.

Esses cálculos mostram, portanto, que o silicato foi fixado em maior proporção que o fosfato, e que ambos os solos fixaram aproximadamente a mesma proporção de silicato nas respectivas doses. Indicam, ainda, que os solos não atingiram a capacidade máxima de fixação de fosfato e silicato, e, nesse caso, a adição de maiores quantidades de silicato na forma de silicato de cálcio poderia fazer com que o fósforo aplicado e adsorvido ao complexo coloidal fosse deslocado para a solução do solo; o resultado seria um aumento da disponibilidade de fósforo para a planta, o que confirmaria o efeito positivo do silicato sobre o aproveitamento do nutriente pelos vegetais (SCARSETH, 1965; SHERMANN, 1969 e PLUCKNETT, 1972).

OLIVEIRA (1984), estudando o deslocamento recíproco de silício e fósforo em amostras de dois solos nos seus respectivos limites de máxima adsorção de $\mathrm{Si} \mathrm{e} \mathrm{P}$, encontrou que, para o LEdm e LRd, as quantidades máximas de P deslocadas pelo silício foram, respectivamente, de 0,023 e $0,176 \mathrm{mg} / \mathrm{g}$ de $\mathrm{P}$, correspondendo a $17,7 \%$ e $13,4 \%$ 
da quantidade de $\mathrm{P}$ adicionada aos respectivos solos. Entretanto, as quantidades máximas de silício deslocadas pelo fósforo foram, respectivamente, de 0,175 e $0,130 \mathrm{mg} / \mathrm{g} \mathrm{de} \mathrm{Si}$, correspondendo a $43 \%$ e $25 \%$ do silício adicionado aos respectivos solos. O autor conclui que o fósforo tem maior facilidade para deslocar silício do que o contrário. OBIHARA \& RUSSEL (1972), estudando a adsorção competitiva de silicato e fosfato em vários solos, verificaram também que a presença do silício na solução do solo não reduziu a adsorção do fósforo até que $\mathrm{o} \mathrm{pH}$ fosse acima de 6,5. Entretanto, a adsorção de $\mathrm{P}$ reduziu a adsorção de $\mathrm{Si}$ em todos os valores de $\mathrm{pH}$. O que dificulta o deslocamento do P pelo silício talvez seja a baixa solubilidade dos compostos de fósforo.

\subsection{Parâmetros da planta}

\subsubsection{Produção de matéria seca da parte aérea}

A produção de matéria seca foi influenciada significativamente pelos três fatores estudados e pela interação tripla (Tabela 15). Em todas as doses e para todas as fontes de fósforo a produção de matéria seca no solo TE foi superior à obtida no LR (Tabela 16). Este comportamento talvez se deva à maior absorção do fósforo pelas plantas no solo TE, pois, conforme se verá adiante (Tabelas 23 e 25), as plantas cultivadas nesse solo apresentaram maiores teores e quantidades acumuladas desse elemento do que as plantadas no LR; além disso, o TE mostrou maiores valores de saturação por bases (Tabela 7), repercutindo possivelmente em maiores absorçōes de $\mathrm{K}^{+}, \mathrm{Ca}^{+2}$ e $\mathrm{Mg}^{+2}$ pelas plantas de arroz.

Em quase todas as combinações de solos e doses de $\mathrm{P}$ aplicadas, as produções de matéria seca obtidas com a adição de TM e de ST+CAL não diferiram significativamente entre si, sendo, contudo, sempre maiores que as fornecidas pelo ST (Tabela 17). É possível que as maiores produções de matéria seca obtidas com aquelas fontes também se devam à maior disponibilidade do fósforo no solo, fato que se tornou aparente através dos teores de $\mathrm{P}$ extraído pela resina (Tabela 10); além disso, a elevação 
do $\mathrm{pH}$ em $\mathrm{CaCl}_{2}$ e da saturação por bases promovida por aquelas fontes fosfatadas também pode ter contribuído para o maior desenvolvimento das plantas.

Tabela 15 - Valores de F e coeficientes de variação (C.V.) para produção de matéria seca e teores e quantidades acumuladas de silício e fósforo na parte aérea de plantas de arroz cultivadas em amostras de dois solos tratadas com diferentes fontes e doses de fósforo ${ }^{(1)}$.

\begin{tabular}{lccccc}
\hline \hline Causa de & Matéria & Teor de & Silício & Teor de & $\begin{array}{c}\text { Fósforo } \\
\text { variação }\end{array}$ \\
seca & silício & absorv. & fósforo &
\end{tabular}

Valor de $\mathrm{F}$

\begin{tabular}{|c|c|c|c|c|c|}
\hline Solos (S) & $598,57^{* *}$ & $209,74^{* *}$ & $937,51^{* *}$ & $122,94^{* *}$ & $746,53^{* *}$ \\
\hline Fontes $(\mathrm{F})$ & $78,82^{\circ *}$ & $92,87^{* *}$ & $169,26^{* *}$ & $32,58^{* *}$ & $126,63^{* *}$ \\
\hline Doses (D) & $898,00^{* *}$ & $216,33^{* *}$ & $344,89^{* *}$ & $154,89^{* *}$ & $714,12^{* *}$ \\
\hline$S \times F$ & $4,46^{\circ}$ & $18,53^{* *}$ & 0,03 & 2,78 & $13,53^{* *}$ \\
\hline$S \times D$ & $40,10^{* *}$ & $8,03^{* *}$ & $33,97^{* *}$ & $25,99^{* *}$ & $67,94^{* *}$ \\
\hline$F \times D$ & $11,39^{* *}$ & $9,56^{* *}$ & $22,55^{* *}$ & $6,58^{* *}$ & $18,40^{* *}$ \\
\hline$S \times F \times D$ & $3,09^{* *}$ & 2,11 & 1,04 & 0,39 & $5,05^{*}$ \\
\hline
\end{tabular}

(1) * e $*$, valores significativos a $5 \%$ e $1 \%$, respectivamente.

A superioridade das fontes TM e ST + CAL sobre o ST também ficou evidente através das regressões: a produção de matéria seca aumentou consideravelmente com as 
doses de fósforo, mas em ambos os solos esses incrementos foram maiores com a aplicação do TM e do ST+CAL (Figura 6).

Respostas mais favoráveis ao termofosfato em relação aos superfosfatos tem sido observadas em vários experimentos, conforme mostra revisão efetuada por GOEDERT et al. (1986), e em parte são atribuídas ao efeito nutricional e alcalinizante dos silicatos de cálcio e magnésio presentes no termofosfato.

Tabela 16 - Produção de matéria seca pela parte aérea de plantas de arroz cultivadas em amostras de Terra Roxa Estruturada (TE) e Latossolo Roxo (LR) tratadas com diferentes doses de fósforo, para cada fonte fosfatada (média de quatro repetições) ${ }^{(1)}$

\begin{tabular}{|c|c|c|c|c|c|}
\hline \multirow[b]{2}{*}{ Fonte $^{(2)}$} & \multirow[b]{2}{*}{ Solo } & \multicolumn{4}{|c|}{ Dose de fósforo $(\mathrm{mg} / \mathrm{kg}$ de $\mathrm{P}$ ) } \\
\hline & & 0 & 50 & 100 & 200 \\
\hline & & & & & \\
\hline \multirow[t]{2}{*}{ TM } & $\mathrm{TE}$ & $2,29 \mathrm{a}$ & $13,39 \mathrm{a}$ & $14,40 \mathrm{a}$ & $15,03 \mathrm{a}$ \\
\hline & LR & $1,00 \mathrm{~b}$ & $5,36 \mathrm{~b}$ & $9,53 \mathrm{~b}$ & $11,28 \mathrm{~b}$ \\
\hline \multirow[t]{2}{*}{$\mathrm{ST}+\mathrm{CAL}$} & $\mathrm{TE}$ & $2,41 \mathrm{a}$ & $10,55 \mathrm{a}$ & $13,53 \mathrm{a}$ & $15,74 \mathrm{a}$ \\
\hline & LR & $0,98 \mathrm{~b}$ & $5,61 \mathrm{~b}$ & $9,34 \mathrm{~b}$ & $11,30 \mathrm{~b}$ \\
\hline \multirow[t]{2}{*}{ ST } & TE & $2,48 \mathrm{a}$ & $8,85 \mathrm{a}$ & $10,47 \mathrm{a}$ & $12,01 \mathrm{a}$ \\
\hline & LR & $1,00 \mathrm{~b}$ & $3,18 \mathrm{~b}$ & $6,48 \mathrm{~b}$ & $9,78 \mathrm{~b}$ \\
\hline
\end{tabular}

(1)Dentro de cada fonte e de cada dose, médias seguidas por letras iguais não diferem entre si pelo teste de Tukey ao nivel de $5 \%$ de probabilidade.

${ }^{(2)} \mathrm{TM}$, termofosfato magnesiano; ST, superfosfato triplo; $\mathrm{CAL}$, mistura de $\mathrm{CaCO}_{3}$ e $\mathrm{MgCO}_{3}$ na relação 4:1. 

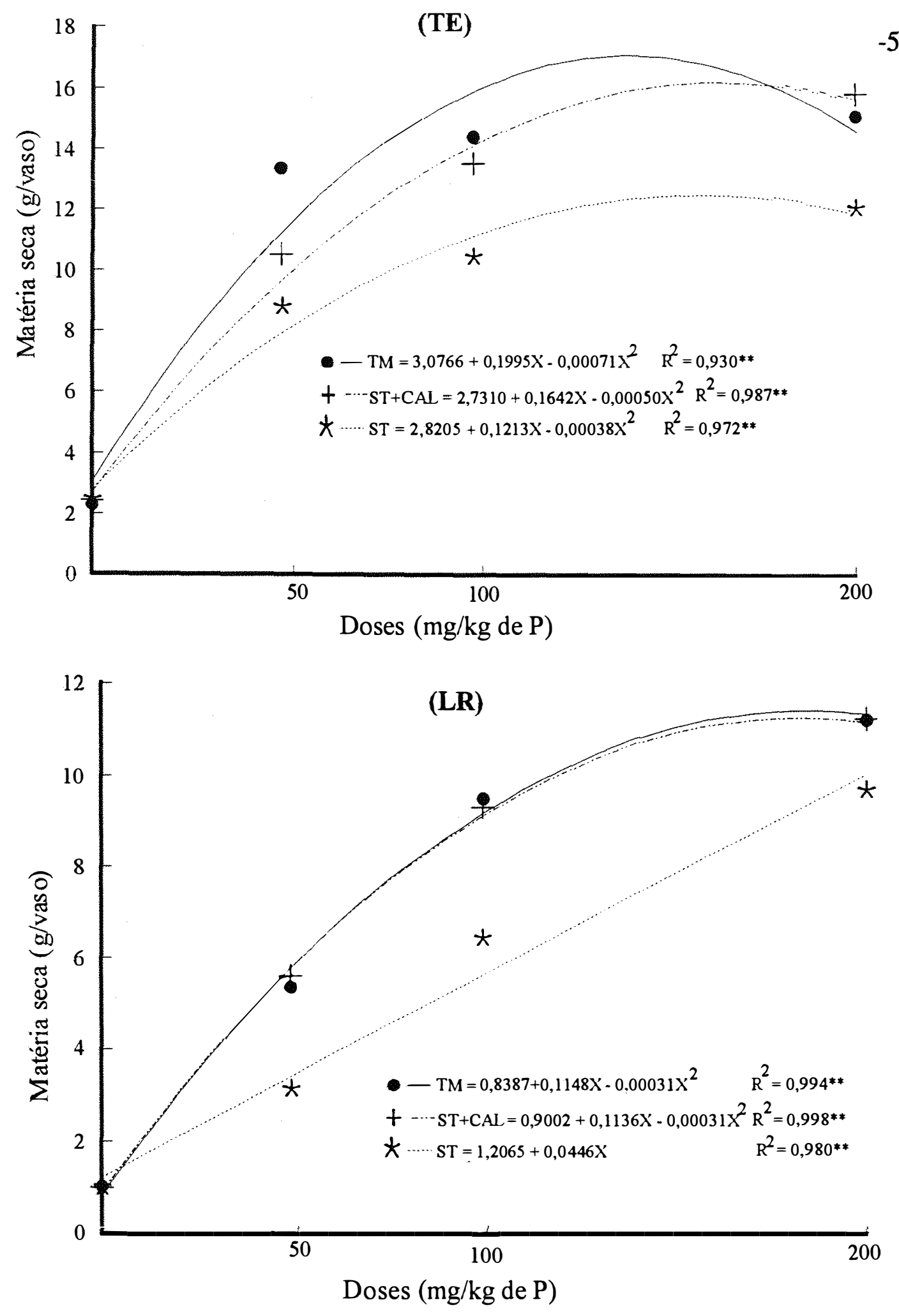

Figura 6. Curvas de resposta da produção de matéria seca da parte aérea das plantas de arroz, para amostras de Terra Roxa Estruturada (TE) e Latossolo Roxo (LR), tratadas com termofosfato magnesiano (TM), superfosfato triplo + calcário (ST+CAL) e superfosfato triplo (ST) em diferentes doses de fósforo. 
Tabela 17 - Produção de matéria seca pela parte aérea de plantas de arroz cultivadas em amostras de terra tratadas com diferentes doses e fontes de fósforo, para cada solo (Terra Roxa Estruturada, TE; e Latossolo Roxo, LR) (média de quatro repetições) ${ }^{(1)}$

\begin{tabular}{|c|c|c|c|c|c|}
\hline \multirow[b]{2}{*}{ Solo } & \multirow[b]{2}{*}{ Fonte $^{(2)}$} & \multicolumn{4}{|c|}{ Dose de fósforo $(\mathrm{mg} / \mathrm{kg}$ de $\mathrm{P})$} \\
\hline & & 0 & 50 & 100 & 200 \\
\hline & & \multicolumn{4}{|c|}{$\mathrm{g} /$ vaso } \\
\hline \multirow[t]{3}{*}{ TE } & $\mathrm{TM}$ & $2,29 \mathrm{aC}$ & $13,39 \mathrm{aB}$ & $14,40 \mathrm{aAB}$ & $15,03 \mathrm{aA}$ \\
\hline & $\mathrm{ST}+\mathrm{CAL}$ & $2,41 \mathrm{aD}$ & $10,55 \mathrm{bC}$ & $13,53 \mathrm{aB}$ & $15,74 \mathrm{aA}$ \\
\hline & ST & $2,48 \mathrm{aD}$ & $8,85 \mathrm{cC}$ & $10,47 \mathrm{bB}$ & $12,01 \mathrm{bA}$ \\
\hline \multirow[t]{3}{*}{ LR } & TM & $1,00 \mathrm{aD}$ & $5,36 \mathrm{aC}$ & $9,53 \mathrm{aB}$ & $11,28 \mathrm{aA}$ \\
\hline & $\mathrm{ST}+\mathrm{CAL}$ & $0,98 \mathrm{aD}$ & $5,61 \mathrm{aC}$ & $9,34 \mathrm{aB}$ & $11,30 \mathrm{aA}$ \\
\hline & ST & $1,00 \mathrm{aD}$ & $3,18 \mathrm{bC}$ & $6,48 \mathrm{bB}$ & $9,78 \mathrm{bA}$ \\
\hline
\end{tabular}

${ }^{(1)}$ Dentro de cada solo, médias seguidas por letras iguais, minúsculas dentro de cada dose e maíusculas dentro de cada fonte, não diferem entre si pelo teste de Tukey ao nível de $5 \%$ de probabilidade.

${ }^{(2)} \mathrm{TM}$, termofosfato magnesiano; ST, superfosfato triplo; $\mathrm{CAL}$, mistura de $\mathrm{CaCO}_{3}$ e $\mathrm{MgCO}_{3}$ na relação 4:1.

\subsubsection{Teor de silício na parte aérea}

Para esta variável, houve efeito significativo dos três fatores estudados e das três interações duplas (Tabela 15); a interação tripla não foi significativa. Os teores de silício das plantas cultivadas no solo TE foram sempre superiores aos daquelas desenvolvidas no LR, tanto para as amostras nã̃o tratadas quanto para as adubadas com fósforo (Tabela 18). Essa diferença pode ser atribuída ao fato de o TE possuir quantidades bem maiores de sílica solúvel que o LR (Tabela 13).

As plantas adubadas com o TM apresentaram os teores mais elevados de silício, seguindo-se as ratadas com ST e, por último, as que receberam ST+CAL (Tabela 19). Esses resultados estão coerentes com os teores de sílica solúvel encontrados nas terras dos 
respectivos tratamentos (Tabela 14). Conforme comentado quando se discutiu esses teores (item 4.1.4), as altas concentrações de silício nas plantas que receberam o TM devem-se à presença de silicato nesse fertilizante, enquanto o maior teor naquelas adubadas com 0 $\mathrm{ST}$, em relação ao $\mathrm{ST}+\mathrm{CAL}$, provavelmente resultou da maior adsorção do silicato quando este último foi aplicado (efeito causado pelo aumento do $\mathrm{pH}$ devido à presença de calcário).

Tabela 18 - Teores de silício na parte aérea de plantas de arroz cultivadas em amostras de Terra Roxa Estruturada (TE) e Latossolo Roxo (LR) tratadas com diferentes doses de fósforo (média de quatro repetições e de três fontes fosfatadas: termofosfato magnesiano, superfosfato triplo + calcário e superfosfato triplo) ${ }^{(1)}$

\begin{tabular}{lcccc}
\hline \hline & \multicolumn{4}{c}{ Dose de fósforo $(\mathrm{mg} / \mathrm{kg}$ de $\mathrm{P})$} \\
\cline { 2 - 5 } Solo & 0 & 50 & 100 & 200 \\
\hline \multicolumn{5}{c}{$\mathrm{g} / \mathrm{kg} \mathrm{de} \mathrm{Si}$} \\
$\mathrm{TE}$ & $35,4 \mathrm{aA}$ & $25,1 \mathrm{aB}$ & $22,0 \mathrm{aC}$ & $20,8 \mathrm{aC}$ \\
$\mathrm{LR}$ & $26,7 \mathrm{bA}$ & $22,0 \mathrm{bB}$ & $16,5 \mathrm{bC}$ & $14,1 \mathrm{bD}$ \\
\hline \hline
\end{tabular}

(1) Médias seguidas por letras iguais, minúsculas dentro de cada dose e maíusculas dentro de cada solo, não diferem entre si pelo teste de Tukey ao nível de $5 \%$ de probabilidade.

(2)TM, termofosfato magnesiano; ST, superfosfato triplo; $\mathrm{CAL}$, mistura de $\mathrm{CaCO}_{3}$ e $\mathrm{MgCO}_{3}$ na relação 4:1.

O efeito das fontes sobre o teor de silício nas plantas não foi exatamente 0 mesmo em ambos os solos (Tabela 20); no TE, os teores obtidos com a aplicação do TM e do $\mathrm{ST}$, respectivamente 27,6 e $26,3 \mathrm{~g} / \mathrm{kg}$ de $\mathrm{Si}$, não diferiram entre si, mas superaram o teor verificado com o $\mathrm{ST}+\mathrm{CAL}(23,5 \mathrm{~g} / \mathrm{kg}$ de $\mathrm{Si})$. No $\mathrm{LR}$, as fontes apresentaram-se na ordem $\mathrm{TM}>\mathrm{ST}>\mathrm{ST}+\mathrm{CAL}$, conferindo na planta teores de $\mathrm{Si}$ iguais a 25,2, 18,8 e $15,5 \mathrm{~g} / \mathrm{kg}$, respectivamente. 
Tabela 19 - Teores de silício na parte aérea de plantas de arroz cultivadas em amostras de solo tratadas com diferentes doses e fontes de fósforo (médias de quatro repetições e de dois solos, Terra Roxa Estruturada e Latossolo Roxo) ${ }^{(1)}$

\begin{tabular}{lcccc}
\hline \hline & \multicolumn{5}{c}{ Dose de fósforo $(\mathrm{mg} / \mathrm{kg}$ de P) } \\
\cline { 2 - 5 } Fonte $^{(2)}$ & 0 & \multicolumn{5}{c}{50} & 100 & 200 \\
\hline \multicolumn{5}{c}{$\mathrm{g} / \mathrm{kg} \mathrm{de} \mathrm{Si}$} \\
TM & $32,3 \mathrm{aA}$ & $26,2 \mathrm{aB}$ & $23,8 \mathrm{aBC}$ & $23,2 \mathrm{aC}$ \\
ST+CAL & $30,9 \mathrm{aA}$ & $20,4 \mathrm{bB}$ & $14,1 \mathrm{cC}$ & $12,5 \mathrm{cC}$ \\
ST & $30,1 \mathrm{aA}$ & $24,0 \mathrm{aB}$ & $19,7 \mathrm{bC}$ & $16,6 \mathrm{bD}$ \\
\hline \hline
\end{tabular}

${ }^{(1)}$ Médias seguidas por letras iguais, minúsculas dentro de cada dose e maíusculas dentro de cada fonte, não diferem entre si pelo teste de Tukey ao nivel de $5 \%$ de probabilidade.

${ }^{(2)} \mathrm{TM}$, termofosfato magnesiano; ST, superfosfato triplo; $\mathrm{CAL}$, mistura de $\mathrm{CaCO}_{3}$ e $\mathrm{MgCO}_{3}$ na relação 4:1.

Tabela 20 - Teores de silício na parte aérea de plantas de arroz cultivadas em amostras de Terra Roxa Estruturada (TE) e Latossolo Roxo (LR) tratadas com diferentes fontes de fósforo (média de quatro repetições e de quatro doses de fósforo: $0,50,100$ e 200 $\mathrm{mg} / \mathrm{kg}$ de $\mathrm{P})^{1}$

\begin{tabular}{lccc}
\hline & \multicolumn{3}{c}{ Fontes de fósforo } \\
\cline { 2 - 4 } Solo & TM & ST +CAL & ST \\
\hline & & g/kg de Si & \\
TE & $27,6 \mathrm{~A}$ & $23,5 \mathrm{~B}$ & $26,3 \mathrm{~A}$ \\
$\mathrm{LR}$ & $25,2 \mathrm{~A}$ & $15,5 \mathrm{C}$ & $18,8 \mathrm{~B}$ \\
\hline
\end{tabular}

(1) Dentro de cada solo, médias seguidas por letras iguais não diferem entre si pelo teste de Tukey ao nível de $5 \%$ de probabilidade.

${ }^{(2)} \mathrm{TM}$, termofosfato magnesiano; ST, superfosfato triplo; $\mathrm{CAL}$, mistura de $\mathrm{CaCO}_{3}$ e $\mathrm{MgCO}_{3}$ na relação 4:1.

As regressões mostraram acentuados decréscimos dos teores de silício nas plantas com o aumento da dose de fósforo, principalmente quando este foi fornecido nas 
formas de ST +CAL e ST (Figura 7a); para o TM, a queda foi atenuada devido à presença de silício nesse fertilizante. $O$ decréscimo do teor de silício nas plantas cultivadas no solo LR foi um pouco mais acentuado que o daquelas plantadas no TE (Figura $7 b$ ).

A diminuição do teor de silício nas plantas com a adição de fósforo deve-se ao efeito da diluição, isto é, aumento acentuado na produção de matéria seca (Figura 6), não acompanhado de aumento igual na absorção do silício, além disso, embora a adição de $\mathbf{P}$ tenha reduzido acentuadamente os teores de $\mathrm{Si}$, a adição de $\mathrm{Si}$ não reduziu os de $\mathrm{P}$ na parte aérea das plantas de arroz (Figura 9a); essas observações levam a supor que o P provavelmente tenha inibido a absorção de $\mathrm{Si}$, mas que o $\mathrm{Si}$ não tenha inibido a de $\mathrm{P}$; o silício contido no TM, ao contrário, chegou mesmo a promover aumentos na quantidade de fósforo acumulada, conforme se verá adiante na Tabela 26. Ganssmann ${ }^{1}$, citado por JONES \& HANDRECK (1967), constatou que aumentos na dose de fósforo, aplicado na forma de fosfato bicálcico, foram acompanhados de aumentos na produção de matéria seca e de diminuições no teor de silício em plantas de trigo. GURGEL (1979), estudando a influência da relação silício/fósforo no estado nutricional, na produtividade e na qualidade tecnológica da cana-de-açúcar, verificou que a adição de silicato ao solo promoveu aumento do teor de silício na folha, enquanto a adição de fósforo causou redução desse teor, principalmente aos nove meses de idade da cultura.

As médias gerais dos teores de silício encontradas na parte aérea das plantas de arroz no presente experimento foram, para as fontes TM, ST e ST +CAL, iguais a 26,4, 22,6 e 19,5 g/kg de $\mathrm{Si}$, respectivamente. Para as plantas não tratadas com fósforo, os teores foram 35,4 e $26,7 \mathrm{~g} / \mathrm{kg}$ de Si, respectivamente para os solos TE e LR. Esses valores são comparáveis aos encontrados na literatura nacional: FURLANI \& GALLO (1978) citam, para a parte aérea de plantas de arroz, um teor de $14,4 \mathrm{~g} / \mathrm{kg}$ de $\mathrm{Si}$, enquanto MALAVOLTA (1980) apresenta valores, para folhas + colmos, variando entre 27,9 e 62,2 $\mathrm{g} / \mathrm{kg}$ de Si para arroz irrigado, e entre 11,6 e 19,6 g/kg de Si para arroz de sequeiro. 

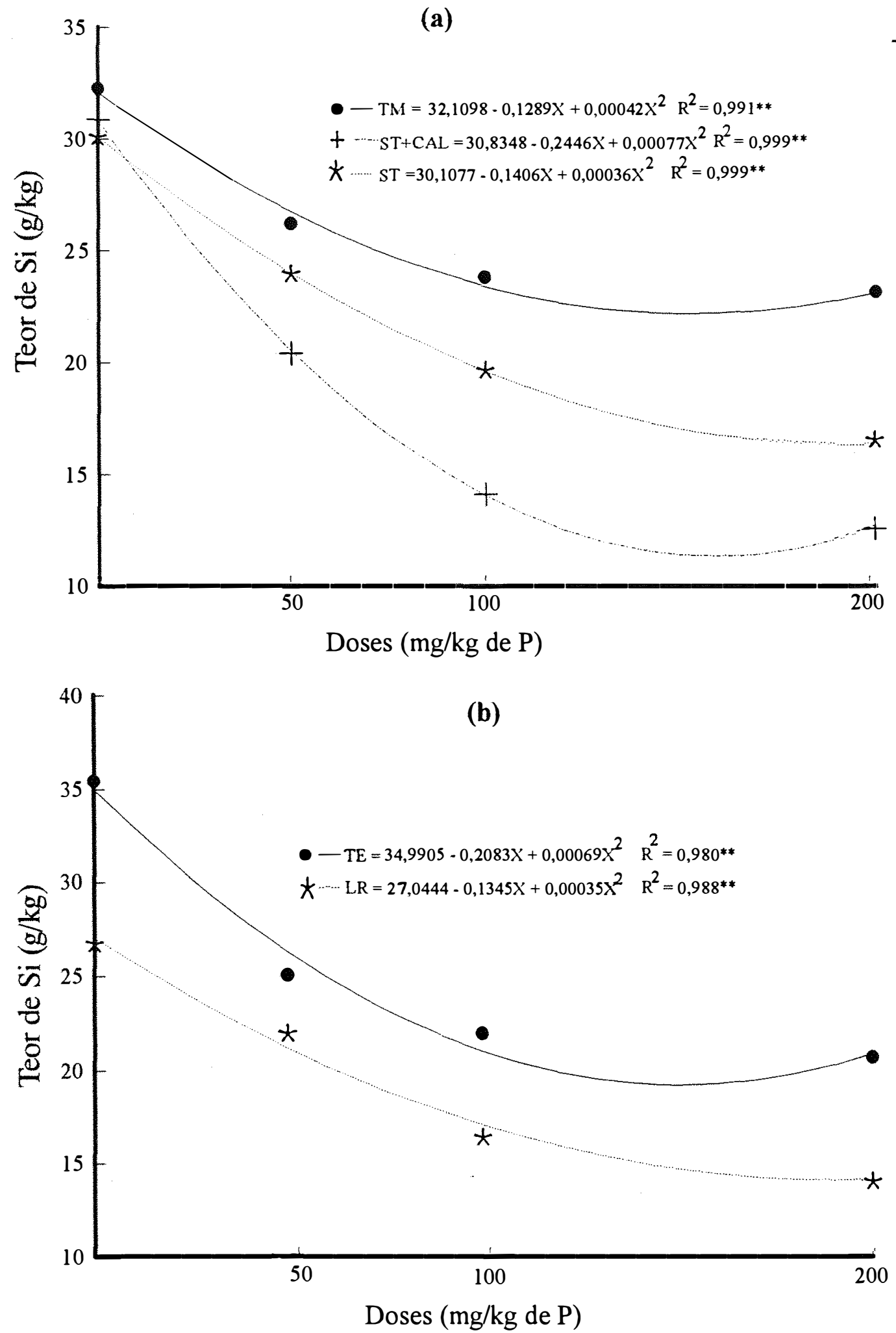

Figura 7. Teores de silício na parte aérea das plantas de arroz (a) de amostras de solo tratadas com termofosfato magnesiano (TM), superfosfato triplo + calcário $(\mathrm{ST}+\mathrm{CAL})$ e superfosfato triplo (ST) em diferentes doses de fósforo (médias de dois solos) e (b) de amostras de Terra Roxa Estruturada (TE) e Latossolo Roxo (LR), tratadas com diferentes doses de fósforo (médias de três fontes de fósforo). 


\subsubsection{Quantidade de silício acumulada na parte aérea}

Houve efeito dos três fatores estudados e de duas interações duplas (solos $\mathbf{x}$ doses e fontes $\mathrm{x}$ doses) sobre a quantidade de silício acumulada na parte aérea (Tabela 15); a interação tripla não foi significativa. As plantas absorveram mais silício no TE do que no LR (Tabela 21); essa observação está coerente com os teores de silício encontrados nas plantas (Tabela 18) e com os teores de sílica solúvel desses solos (Tabela 13). Conforme cita MALAVOLTA (1980), a velocidade de absorção de um elemento pela planta cresce com sua concentração no meio externo.

A maior absorção de silício ocorreu nas plantas tratadas com o TM, seguindo-se as adubadas com o ST + CAL e com o ST, os quais não diferiram entre si (Tabela 22).

Tabela 21. Quantidades de silício acumuladas na parte aérea de plantas de arroz cultivadas em amostras de Terra Roxa Estruturada (TE) e Latossolo Roxo (LR) tratadas com diferentes doses de fósforo (média de quatro repetiçōes e de três fontes fosfatadas: termofosfato magnesiano, superfosfato triplo + calcário e superfosfato triplo) ${ }^{(1)}$

\begin{tabular}{lcccc}
\hline \hline & \multicolumn{4}{c}{ Dose de fósforo $(\mathrm{mg} / \mathrm{kg}$ de $\mathrm{P})$} \\
\cline { 2 - 5 } Solo & 0 & 50 & 100 & 200 \\
\hline \multirow{4}{*}{$\mathrm{mE}$} & $84,4 \mathrm{aB}$ & $273,2 \mathrm{aA} /$ vaso de $\mathrm{Si}$ & $279,9 \mathrm{aA}$ & $292,7 \mathrm{aA}$ \\
& & & & \\
LR & $26,5 \mathrm{bC}$ & $102,4 \mathrm{bB}$ & $139,8 \mathrm{bA}$ & $153,2 \mathrm{bA}$ \\
\hline \hline
\end{tabular}

${ }^{(1)}$ Médias seguidas por letras iguais, minúsculas dentro de doses e maíusculas dentro de solos, não diferem entre si pelo teste de Tukey ao nível de 5\% de probabilidade.

${ }^{(2)} \mathrm{TM}$, termofosfato magnesiano; ST, superfosfato triplo; $\mathrm{CAL}$, mistura de $\mathrm{CaCO}_{3}$ e $\mathrm{MgCO}_{3}$ na relação 4:1. 
Tabela 22 - Quantidades de silício acumuladas na parte aérea de plantas de arroz cultivadas em amostras de solo tratadas com diferentes doses e fontes de fósforo (médias de quatro repetições e de dois solos, Terra Roxa Estruturada e Latossolo Roxo) ${ }^{(1)}$

\begin{tabular}{lcccc}
\hline & \multicolumn{5}{c}{ Dose de fósforo $(\mathrm{mg} / \mathrm{kg}$ de $\mathrm{P})$} \\
\cline { 2 - 5 } Fonte $^{(2)}$ & 0 & 50 & 100 & 200 \\
\hline \multicolumn{5}{c}{$\mathrm{mg} /$ vaso de Si } \\
TM & $55,2 \mathrm{aC}$ & $242,3 \mathrm{aB}$ & $287,2 \mathrm{aA}$ & $307,4 \mathrm{aA}$ \\
ST+CAL & $56,1 \mathrm{aB}$ & $172,5 \mathrm{bA}$ & $167,1 \mathrm{bA}$ & $175,8 \mathrm{bA}$ \\
ST & $55,1 \mathrm{aC}$ & $148,6 \mathrm{bB}$ & $175,3 \mathrm{bAB}$ & $185,7 \mathrm{bA}$ \\
\hline
\end{tabular}

(1) Médias seguidas por letras iguais, minúsculas dentro de cada dose e maíusculas dentro de cada fonte, não diferem entre si pelo teste de Tukey ao nível de $5 \%$ de probabilidade.

${ }^{(2)} \mathrm{TM}$, termofosfato magnesiano; ST, superfosfato triplo; $\mathrm{CAL}$, mistura de $\mathrm{CaCO}_{3}$ e $\mathrm{MgCO}_{3}$ na relação 4:1.

As regressōes mostram que as quantidades de silício acumuladas na planta aumentaram com as doses de fósforo e que esses aumentos foram maiores quando se aplicou o TM devido à presença de silicato nesse material (Figura 8a). Os incrementos nas quantidades acumuladas de silício foram devidos exclusivamente aos elevados aumentos verificados na produção de matéria seca com as doses de fósforo (Figura 6), já que os teores de silício na planta diminuiram com essas doses (Figura 7).

Para todas as fontes houve apreciáveis aumentos na quantidade de silício acumulada quando se aplicou a dose mais baixa de fósforo, $50 \mathrm{mg} / \mathrm{kg}$ de P; a partir desse nível os aumentos foram cada vez menores (Figura 8a). No solo TE as quantidades acumuladas de silício aumentaram, em média, de 99,3 para 287,8 mg/vaso, enquanto no LR a quantidade variou de 28,0 para 152,7 mg/vaso (Figura $8 b$ ). 

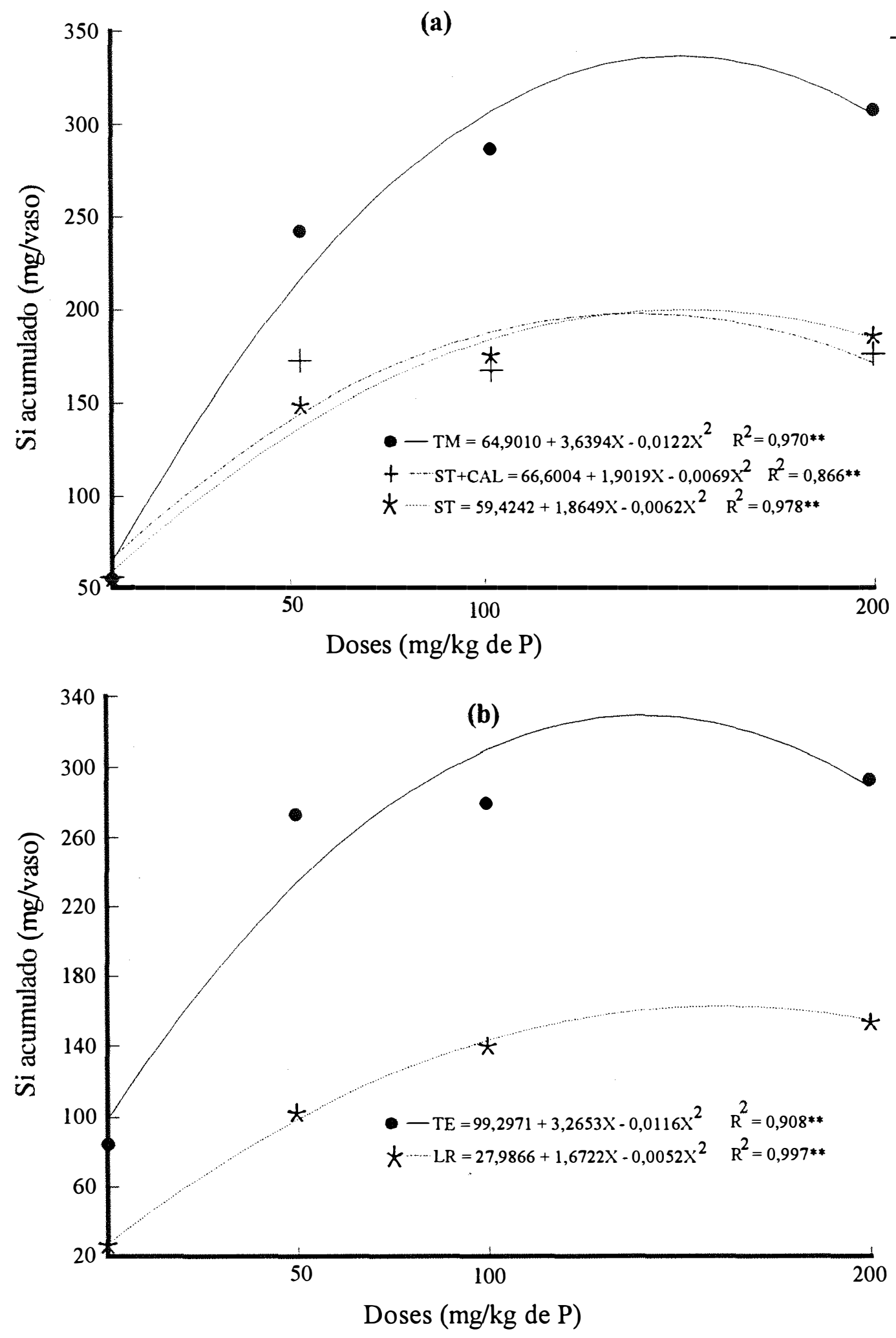

Figura 8. Curvas de resposta do silício acumulado na parte aérea das plantas de arroz (a) de amostras de solo tratadas com termofosfato magnesiano (TM), superfosfato triplo + calcário (ST+CAL) e superfosfato triplo (ST) em diferentes doses de fósforo (médias de dois solos) e (b) de amostras de Terra Roxa Estruturada (TE) e Latossolo Roxo (LR), tratadas com diferentes doses de fósforo (médias de três fontes de fósforo). 


\subsubsection{Teor de fósforo na parte aérea}

Houve efeito significativo dos três fatores avaliados e apenas de duas interações duplas (solos $\mathrm{x}$ doses $\mathrm{e}$ fontes $\mathrm{x}$ doses) sobre $\mathrm{o}$ teor de fósforo na parte aérea (Tabela 15); o efeito da interação tripla não foi significativo. As plantas cultivadas nas amostras não tratadas dos solos TE e LR apresentaram teores de fósforo semelhantes, mas quando o fósforo foi aplicado, em todas as doses as plantas cultivadas no TE apresentaram teores mais elevados que as desenvolvidas no LR (Tabela 23). Esses resultados contrariam o que seria de se esperar com base nos teores de P-resina, os quais, para as doses mais altas de $P$, foram mais elevados no LR que no TE (Tabela 9).

Para a dose $200 \mathrm{mg} / \mathrm{kg}$ de $\mathrm{P}$, o TM proporcionou o maior teor de fósforo da parte aérea $(1,85 \mathrm{~g} / \mathrm{kg}$ de $\mathrm{P})$, sendo seguido pelo ST $+\mathrm{CAL}(1,64 \mathrm{~g} / \mathrm{kg}$ de $\mathrm{P})$ e pelo ST $(1,43 \mathrm{~g} / \mathrm{kg}$ de P) (Tabela 24). Para a dose $100 \mathrm{mg} / \mathrm{kg}$ de $\mathrm{P}$ as fontes TM e ST +CAL proporcionaram teores semelhantes de $\mathrm{P}$, mas superiores ao ST, enquanto na dose 50 $\mathrm{mg} / \mathrm{kg}$ de $\mathrm{P}$ a fonte TM foi significativamente superior às outras.

As regressões polinomiais mostraram que, para todas as fontes de fósforo, os teores do elemento na planta responderam aos aumentos nas doses segundo equações quadráticas (Figura 9a); os aumentos foram decrescentes até a dose máxima e mostraram-se mais expressivos para a fonte TM, seguida do ST + CAL e do ST. Dentre os solos, os aumentos foram consideravelmente maiores no TE que no LR (Figura 9b).

Com os dados da Tabela 24 pode-se calcular que os teores médios de fósforo encontrados na parte aérea das plantas de arroz tratadas com as fontes TM, ST + CAL e ST foram 1,43, 1,30 e 1,17 g/kg de $P$, respectivamente; esses valores estão bem acima dos 0,56 e 0,52 g/kg observados por ROCHA (1994) em plantas de arroz adubadas respectivamente com termofosfato magnesiano e superfosfato triplo e colhidas com 32 dias de idade. Os índices assemelham-se muito, porém, aos encontrados por MÉNDEZ (1986) e BARBOSA FILHO (1986) em plantas de arroz adubadas com superfosfato triplo e colhidas aos 60 dias: respectivamente 1,26 e $1,38 \mathrm{~g} / \mathrm{kg}$ de $P$. 
Tabela 23 - Teores de fósforo na parte aérea de plantas de arroz cultivadas em amostras de Terra Roxa Estruturada (TE) e Latossolo Roxo (LR) tratadas com diferentes doses de fósforo (média de quatro repetições e de três fontes fosfatadas: termofosfato magnesiano, superfosfato triplo + calcário e superfosfato triplo) ${ }^{(1)}$

\begin{tabular}{lcccr}
\hline & \multicolumn{5}{c}{ Dose de fósforo $(\mathrm{mg} / \mathrm{kg}$ de $\mathrm{P})$} \\
\cline { 2 - 5 } Solo & 0 & 50 & 100 & 200 \\
\hline & \multicolumn{5}{c}{$\mathrm{g} / \mathrm{kg} \mathrm{de} \mathrm{P}$} \\
$\mathrm{TE}$ & $0,85 \mathrm{aD}$ & $1,32 \mathrm{aC}$ & $1,70 \mathrm{aB}$ & $1,93 \mathrm{aA}$ \\
$\mathrm{LR}$ & $0,91 \mathrm{aC}$ & $1,08 \mathrm{bB}$ & $1,27 \mathrm{bA}$ & $1,35 \mathrm{bA}$ \\
& & & & \\
\hline
\end{tabular}

(1) Dentro de cada solo, médias seguidas por letras iguais, minúsculas dentro de doses e maíusculas dentro de solos, não diferem entre si pelo teste de Tukey ao nível de $5 \%$ de probabilidade.

${ }^{2} \mathrm{TM}$, termofosfato magnesiano; ST, superfosfato triplo; $\mathrm{CAL}$, mistura de $\mathrm{CaCO}_{3}$ e $\mathrm{MgCO}_{3}$ na relação 4:1.

Tabela 24 - Teores de fósforo na parte aérea de plantas de arroz cultivadas em amostras de solo tratadas com diferentes doses e fontes de fósforo (médias de quaro repetições e de dois solos, Terra Roxa Estruturada e Latossolo Roxo) ${ }^{(1)}$

\begin{tabular}{lcccc}
\hline \hline & \multicolumn{5}{c}{ Dose de fósforo $(\mathrm{mg} / \mathrm{kg}$ de P) } \\
\cline { 2 - 5 } Fonte ${ }^{(2)}$ & 0 & 50 & 100 & 200 \\
\hline \multicolumn{5}{c}{$\mathrm{g} / \mathrm{kg}$ de $\mathrm{P}$} \\
$\mathrm{TM}$ & $0,84 \mathrm{aD}$ & $1,40 \mathrm{aC}$ & $1,64 \mathrm{aB}$ & $1,85 \mathrm{aA}$ \\
$\mathrm{ST}+\mathrm{CAL}$ & $0,92 \mathrm{aC}$ & $1,11 \mathrm{bB}$ & $1,54 \mathrm{aA}$ & $1,64 \mathrm{bA}$ \\
ST & $0,89 \mathrm{aC}$ & $1,08 \mathrm{bB}$ & $1,28 \mathrm{bA}$ & $1,43 \mathrm{cA}$ \\
\hline \hline
\end{tabular}

${ }^{(1)}$ Médias seguidas por letras iguais, minúsculas dentro de cada dose e maíusculas dentro de cada fonte, não diferem entre si pelo teste de Tukey ao nível de $5 \%$ de probabilidade.

${ }^{(2)} \mathrm{TM}$, termofosfato magnesiano; ST, superfosfato triplo; $\mathrm{CAL}$, mistura de $\mathrm{CaCO}_{3}$ e $\mathrm{MgCO}_{3}$ na relação 4:1. 

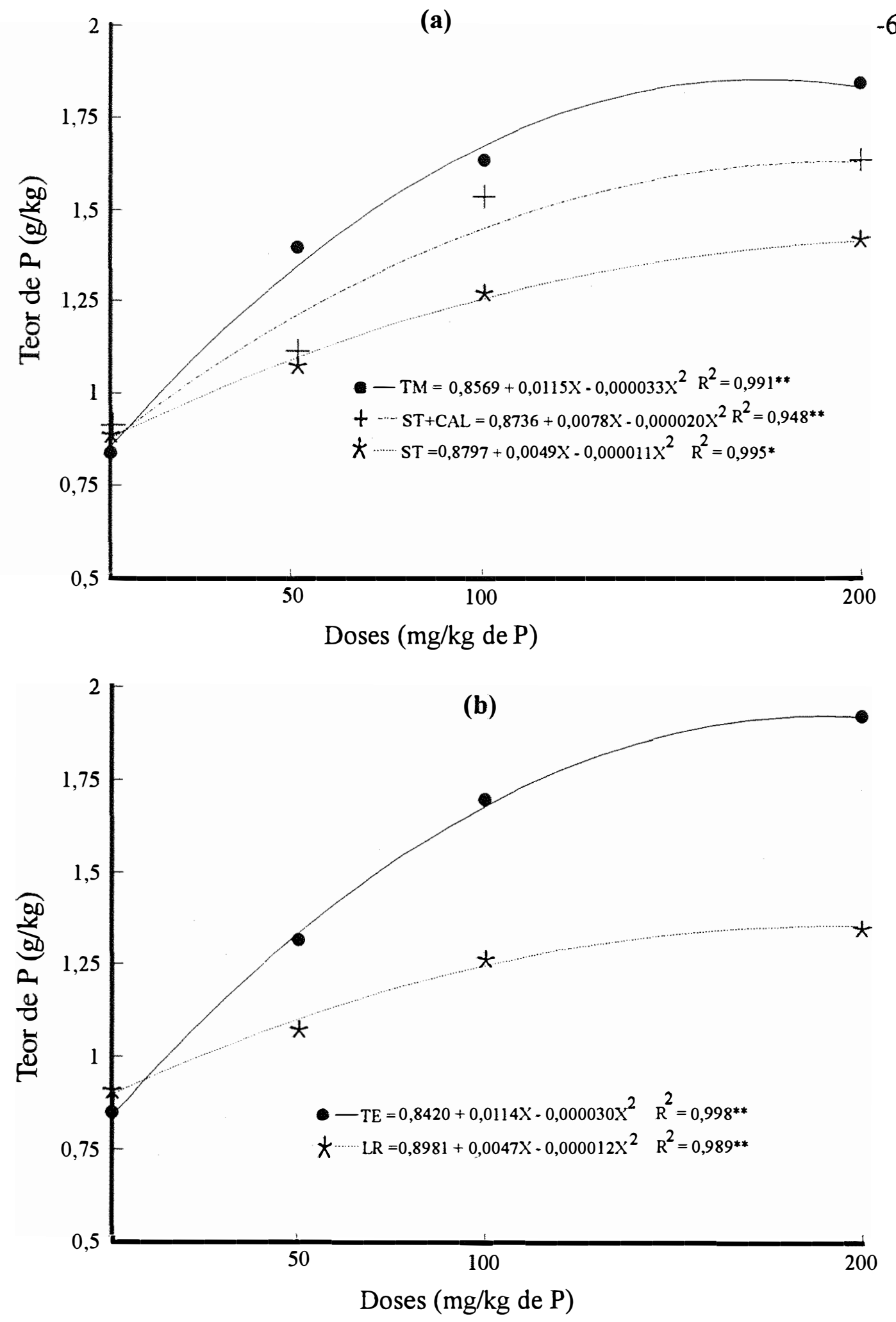

Figura 9. Teores de fósforo na parte aérea das plantas de arroz (a) de amostras de solo tratadas com termofosfato magnesiano (TM), superfosfato triplo + calcário $(\mathrm{ST}+\mathrm{CAL})$ e superfosfato triplo (ST) em diferentes doses de fósforo (médias de dois solos) e (b) de amostras de Terra Roxa Estruturada (TE) e Latossolo Roxo (LR), tratadas com diferentes doses de fósforo (médias de três fontes de fósforo). 


\subsubsection{Quantidade de fósforo acumulada na parte aérea}

Esse parâmetro foi influenciado significativamente pelos três fatores estudados e pela interação tripla entre eles (Tabela 15). À semelhança do que ocorreu com o teor de $\mathrm{P}$, nas amostras não tratadas não houve diferença significativa entre os solos quanto à quantidade de fósforo acumulada na parte aérea (Tabela 25). Contudo, quando adubadas, as plantas retiraram mais fósforo do solo TE do que do LR, independentemente da fonte e das doses de $\mathrm{P}$ fornecidas.

Aqui também os resultados contrariam o que seria de se esperar com base nos teores de P-resina, os quais foram, em geral, mais elevados no LR do que no TE (Tabela 9). É possível que a maior absorção de fósforo no solo TE se deva aos valores mais elevados de saturação por bases ocorridos nesse solo (Tabela 7), os quais geralmente significam maior disponibilidade de cálcio trocável; a presença do cálcio, por sua vez, estimularia o desenvolvimento radicular, aumentando a demanda desse elemento e do fósforo pelas plantas. KHASAWNEH \& DOLL (1978) assinalam que as diferenças entre culturas quanto à habilidade de utilizar fósforo estão relacionadas aos seus padrões de demanda de $\mathrm{Ca}$ e $\mathrm{P}$ e à maneira como essa demanda altera a composição da solução do solo na interface solo-raiz. Portanto, é provável que no presente estudo a exploração da amostra de terra pelo sistema radicular das plantas de arroz tenha sido mais intensa no TE do que no LR, resultando maiores índices de absorção de fósforo e produções de matéria seca naquele solo.

Os resultados da Tabela 26, juntamente com os da Tabela 17, têm elevada significância para o presente trabalho, uma vez que permitem comparar o efeito das três fontes estudadas, sobre duas variáveis importantes: a quantidade de fósforo acumulada na planta e a produção de matéria seca. A análise desses resultados é dificultada pelo fato de a interação ter sido tripla em ambos os casos, significando que o efeito das fontes não foi o mesmo em todas as doses e em ambos os solos. Contudo, avaliando-se as seis combinações entre solos e doses (não considerando a dose zero), verifica-se que em cinco 
combinações (doses 100 e $200 \mathrm{mg} / \mathrm{kg}$ de P para o solo TE e 50,100 e $200 \mathrm{mg} / \mathrm{kg}$ de P para o LR) para o caso da variável produção de matéria seca (Tabela 17), e em quatro (doses 100 e $200 \mathrm{mg} / \mathrm{kg}$ de P para o TE e 50 e $100 \mathrm{mg} / \mathrm{kg}$ de $P$ para o LR), para o caso da variável fósforo acumulado (Tabela 26), as fontes TM e ST + CAL não diferiram entre si, mas foram superiores ao ST. Em outras palavras, o efeito favorável do TM sobre o aproveitamento do fósforo e o desenvolvimento das plantas parece ter sido mais conseqüência da sua capacidade de elevar o $\mathrm{pH}$ do meio do que da influência benéfica da competição entre o silicato que este contém e o fosfato, pelos mesmos sítios de adsorção. Esse efeito tem a ver, portanto, com a primeira das três hipóteses formuladas inicialmente.

Tabela 25 - Quantidades de fósforo acumuladas na parte aérea de plantas de arroz cultivadas em amostras de Terra Roxa Estruturada (TE) e Latossolo Roxo (LR) tratadas com diferentes doses de fósforo, para cada fonte fosfatada (média de quatro repetiçōes) ${ }^{(1)}$

\begin{tabular}{|c|c|c|c|c|c|}
\hline \multirow[b]{2}{*}{ Fonte $^{(2)}$} & \multirow[b]{2}{*}{ Solo } & \multicolumn{4}{|c|}{ Dose de fósforo $(\mathrm{mg} / \mathrm{kg}$ de $\mathrm{P})$} \\
\hline & & 0 & 50 & 100 & 200 \\
\hline & & \multicolumn{4}{|c|}{$\mathrm{mg} /$ vaso de $\mathrm{P}$} \\
\hline \multirow[t]{2}{*}{ TM } & $\mathrm{TE}$ & $1,83 \mathrm{a}$ & $20,08 \mathrm{a}$ & $26,29 \mathrm{a}$ & $31,56 \mathrm{a}$ \\
\hline & LR & $0,88 \mathrm{a}$ & $6,97 \mathrm{~b}$ & $13,90 \mathrm{~b}$ & $18,05 \mathrm{~b}$ \\
\hline \multirow[t]{2}{*}{$\mathrm{ST}+\mathrm{CAL}$} & $\mathrm{TE}$ & $2,18 \mathrm{a}$ & $13,28 \mathrm{a}$ & $24,70 \mathrm{a}$ & $31,48 \mathrm{a}$ \\
\hline & LR & $0,92 \mathrm{a}$ & $5,44 \mathrm{~b}$ & $11,62 \mathrm{~b}$ & $14,33 \mathrm{~b}$ \\
\hline \multirow[t]{2}{*}{ ST } & $\mathrm{TE}$ & $2,13 \mathrm{a}$ & $10,63 \mathrm{a}$ & $15,25 \mathrm{a}$ & $20,14 \mathrm{a}$ \\
\hline & LR & $0,92 \mathrm{a}$ & $3,05 \mathrm{~b}$ & $7,12 \mathrm{~b}$ & $11,50 \mathrm{~b}$ \\
\hline
\end{tabular}

(1) Dentro de cada fonte e de cada dose, médias seguidas por letras iguais não diferem entre si pelo teste de Tukey ao nível de $5 \%$ de probabilidade.

${ }^{(2)} \mathrm{TM}$, termofosfato magnesiano; ST, superfosfato triplo; $\mathrm{CAL}$, mistura de $\mathrm{CaCO}_{3}$ e $\mathrm{MgCO}_{3}$ na relação 4:1. 
Tabela 26 - Quantidades de fósforo acumuladas na parte aérea de plantas de arroz cultivadas em amostras de terra tratadas com diferentes doses e fontes de fósforo, para cada solo (Terra Roxa Estruturada, TE; e Latossolo Roxo, LR) (média de quatro repetições) $)^{(1)}$

\begin{tabular}{|c|c|c|c|c|c|}
\hline \multirow[b]{2}{*}{ Solo } & \multirow[b]{2}{*}{ Fonte $^{(2)}$} & \multicolumn{4}{|c|}{ Dose de fósforo $(\mathrm{mg} / \mathrm{kg}$ de $\mathrm{P})$} \\
\hline & & 0 & 50 & 100 & 200 \\
\hline & & & $\mathrm{mg} / \mathrm{s}$ & de $P$ & \\
\hline \multirow[t]{3}{*}{ TE } & TM & $1,83 \mathrm{aD}$ & $20,08 \mathrm{aC}$ & $26,29 \mathrm{aB}$ & $31,56 \mathrm{aA}$ \\
\hline & $\mathrm{ST}+\mathrm{CAL}$ & $2,18 \mathrm{aD}$ & $13,28 \mathrm{bC}$ & $24,70 \mathrm{aB}$ & $31,48 \mathrm{aA}$ \\
\hline & ST & $2,13 \mathrm{aD}$ & $10,63 \mathrm{cC}$ & $15,25 \mathrm{bB}$ & $20,14 \mathrm{bA}$ \\
\hline \multirow[t]{3}{*}{ LR } & TM & $0,88 \mathrm{aD}$ & $6,97 \mathrm{aC}$ & $13,90 \mathrm{aB}$ & 18,05 aA \\
\hline & $\mathrm{ST}+\mathrm{CAL}$ & $0,92 \mathrm{aC}$ & $5,44 \mathrm{abB}$ & $11,62 \mathrm{aA}$ & $14,33 \mathrm{bA}$ \\
\hline & ST & $0,92 \mathrm{aC}$ & $3,05 \mathrm{bC}$ & $7,12 \mathrm{bB}$ & $11,50 \mathrm{cA}$ \\
\hline
\end{tabular}

(1) Dentro de cada solo, médias seguidas por letras iguais, minúsculas dentro de doses e maíusculas dentro de fontes, não diferem entre si pelo teste de Tukey ao nível de 5\% de probabilidade.

${ }^{(2} \mathrm{TM}$, termofosfato magnesiano; ST, superfosfato triplo; CAL, mistura de $\mathrm{CaCO}_{3}$ e $\mathrm{MgCO}_{3}$ na relação 4:1.

Cumpre notar, contudo, que doses baixas permitem distinguir melhor as diferenças entre fontes; assim, quando a dose $50 \mathrm{mg} / \mathrm{kg}$ de $\mathrm{P}$ foi aplicada no solo TE, a eficiência das fontes seguiu a ordem TM $>\mathrm{ST}+\mathrm{CAL}>\mathrm{ST}$, tanto para a produção de matéria seca quanto para a acumulação de fósforo; nesses casos, além da superioridade do ST + CAL sobre o ST, devido ao efeito alcalinizante daquele, houve superioridade do TM sobre o ST +CAL devido, provavelmente, ao efeito da competição entre o silicato contido no TM e o fosfato. Portanto, em relação ao superfosfato triplo, o TM apresentaria dois efeitos adicionais: o efeito alcalinizante e o efeito da competição entre o silicato e o fosfato. Esse comportamento está relacionado, portanto, à terceira das três hipóteses iniciais. ROY 
et al. (1971) constataram que a aplicação de silicato sem fósforo, ou de silicato acompanhado de dose moderada daquele elemento, aumentou o teor de fósforo nas partes verdes de plantas e diminuiu o teor no colmo; quando a silicato era associado a doses maiores de fósforo, contudo, não causava aumento no teor desse nutriente na planta. Esses dados sugerem, segundo os autores, que o silício acelera a mobilização do fósforo dos tecidos menos ativos da planta quando o seu nível é baixo. Observaram ainda que, sem adição de fósforo, o silício aumentou o perfilhamento da planta, fenômeno geralmente associado a condições de adequada nutrição de fósforo.

As curvas de resposta para fósforo acumulado na parte aérea das plantas de arroz em função das doses de fósforo confirmam, para ambos os solos, os efeitos positivos das três fontes de fósforo, principalmente para o TM e o ST+CAL (Figura 10).

Os dados deste estudo também mostram que, sob baixos teores de fósforo no solo, caso das amostras com dose zero, as plantas de arroz absorveram elevadas quantidades de silício e baixas de fósforo, resultando altas relações Si/P acumulados: em média, essas relações foram de 41,4 no solo TE e 29,2 no LR (Tabela 27). Em outras palavras, na falta de fósforo as plantas absorveram relativamente mais silício. Quando se aplicou fósforo, essas relações cairam apreciavelmente com o aumento da dose aplicada, mesmo quando a fonte foi o TM, que contém silício. No solo TE tratado com o TM, por exemplo, as aplicações de 50,100 e $200 \mathrm{mg} / \mathrm{kg}$ de $\mathrm{P}$ reduziram a relação Si/P de 44,4 para $16,9,13,6$ e 11,7 , respectivamente. 

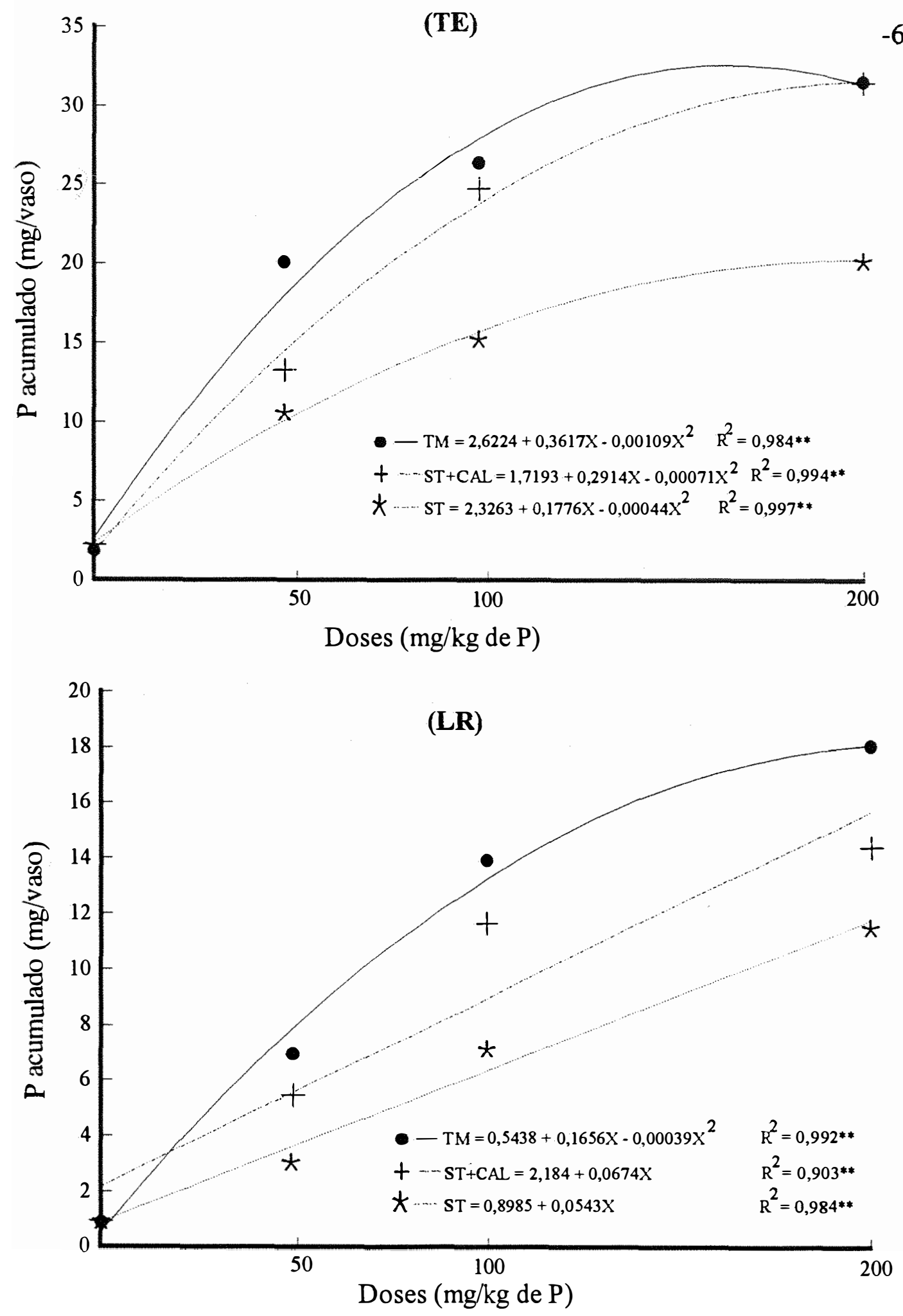

Figura 10. Curvas de resposta do fósforo acumulado na parte aérea das plantas de arroz, para amostras de Terra Roxa Estruturada (TE) e Latossolo Roxo (LR) tratadas com termofosfato magnesiano (TM), superfosfato triplo + calcário $(\mathrm{ST}+\mathrm{CAL})$ e superfosfato triplo (ST) em diferentes doses de fósforo 
Tabela 27 - Relações entre as quantidades de silício e fósforo acumuladas na parte aérea de plantas de arroz cultivadas em amostras de Terra Roxa Estruturada (TE) e Latossolo Roxo (LR) tratadas com diferentes doses e fontes de fósforo

\begin{tabular}{lccccc}
\hline & & \multicolumn{5}{c}{ Dose de fósforo (mg/kg de P) } \\
\cline { 3 - 6 } Fonte $^{(1)}$ & Solo & 0 & 50 & 100 & 200 \\
\hline \multirow{2}{*}{ TM } & & \multicolumn{5}{c}{ Si/P } \\
& TE & 44,4 & 16,9 & 13,6 & 11,7 \\
& LR & 33,0 & 20,8 & 15,7 & 13,5 \\
ST+CAL & & & & & \\
& TE & 40,2 & 19,1 & 9,4 & 7,9 \\
& LR & 26,7 & 16,9 & 8,7 & 7,2 \\
ST & & & & & \\
& TE & 39,6 & 21,4 & 16,4 & 12,9 \\
\hline \hline
\end{tabular}

${ }^{(1)} \mathrm{TM}$, termofosfato magnesiano; ST, superfosfato triplo; $\mathrm{CAL}$, mistura de $\mathrm{CaCO}_{3}$ e $\mathrm{MgCO}_{3}$ na relação 4:1. 


\subsubsection{Correlações entre variáveis}

\section{a) Para combinações de solos e doses}

O estudo de correlações entre os principais parâmetros de planta, realizado para as diversas combinações de solos e doses (Tabela 28) mostrou que no solo TE, em todas as doses a produção de matéria seca dependeu fortemente da quantidade de fósforo acumulada; no LR essa dependência foi menor nas doses 50 e $200 \mathrm{mg} / \mathrm{kg}$ de $P$.

O coeficiente de correlação entre produção de matéria seca e silício acumulado foi alto e significativo somente no solo TE e para a dose $50 \mathrm{mg} / \mathrm{kg}$ de $\mathrm{P}\left(\mathrm{r}=0,90^{* *}\right)$, confirmando que houve efeito favorável do silício apenas no citado solo e no nível mais baixo de $\mathrm{P}$ aplicado, conforme discutido no item anterior. Esse efeito também pode ser constatado pelo elevado coeficiente de correlação $\left(r=0,87^{\circ *}\right)$ verificado no mesmo solo e para a mesma dose, entre as quantidades de fósforo e silício acumuladas. No solo LR, os coeficientes de correlação entre fósforo e silício acumulados foram significativos, porém, menores que os encontrados no TE; além disso, no LR de modo geral não houve dependência entre a produção de matéria seca e a quantidade de silício acumulado, confirmando a ausência do efeito do silício nesse solo.

Para os demais pares de variáveis, os coeficientes de correlação foram baixos e muitas vezes não significativos, provavelmente porque a amplitude de variação dos resultados, quando se comparam as fontes dentro de cada dose, foi pequena.

\section{b) Para combinações de solos e fontes}

O estudo de correlação para as diversas combinações de solos e fontes (Tabela 29) revelou coeficientes mais altos que os anteriores devido à maior amplitude dos resultados, provocada pelo efeito das doses de fósforo. As correlações mais importantes foram as que resultaram coeficientes negativos, todos significativos, por serem os menos previsíveis. Note-se que esses valores negativos ocorreram sempre que a variável teor de silício estava envolvida. 
Tabela 28 - Coeficientes de correlação linear entre algumas variáveis relacionadas à parte aérea de plantas de arroz cultivadas em amostras de Terra Roxa Estruturada (TE) e Latossolo Roxo (LR) tratadas com diferentes doses de fósforo; número de observações igual a 12 (4 repetições $\times 3$ fontes) ${ }^{(1)}$

\begin{tabular}{|c|c|c|c|c|}
\hline \multirow{2}{*}{$\begin{array}{l}\text { Variáveis } \\
\text { correlacionadas }\end{array}$} & \multirow[b]{2}{*}{ Solo } & \multicolumn{3}{|c|}{ Dose de fósforo (mg/kg de P) } \\
\hline & & 50 & 100 & 200 \\
\hline \multirow{2}{*}{ Mat. seca $\times$ P acumulado } & TE & $0,98^{* *}$ & $0,98^{* *}$ & $0,96^{* *}$ \\
\hline & LR & $0,75^{* *}$ & $0,91^{* *}$ & $0,67^{*}$ \\
\hline \multirow[t]{2}{*}{ Mat. seca $x$ Si acumulado } & TE & $0,90^{* *}$ & 0,56 & 0,15 \\
\hline & LR & $0,63^{*}$ & 0,55 & 0,37 \\
\hline \multirow[t]{2}{*}{ Mat. seca $x$ teor de $P$} & $\mathrm{TE}$ & $0,87^{* *}$ & $0,88^{* *}$ & $0,81^{* *}$ \\
\hline & LR & 0,26 & $0,61^{*}$ & 0,31 \\
\hline \multirow{2}{*}{ Mat. seca $\mathrm{x}$ teor de $\mathrm{Si}$} & $\mathrm{TE}$ & $-0,18$ & $-0,20$ & $-0,43$ \\
\hline & LR & $-0,23$ & 0,10 & 0,20 \\
\hline \multirow[t]{2}{*}{ Teor de $\mathrm{P}$ x teor de $\mathrm{Si}$} & TE & $-0,24$ & $-0,31$ & 0,03 \\
\hline & LR & 0,41 & $0,58^{*}$ & $0,78^{* *}$ \\
\hline \multirow[t]{2}{*}{ P acumul. x Si acumul. } & TE & $0,87^{* *}$ & 0,52 & 0,35 \\
\hline & LR & $0,78^{* *}$ & $0,75^{* *}$ & $0,79^{* *}$ \\
\hline \multirow[t]{2}{*}{$\mathrm{P}$ acumul. $\mathrm{x}$ teor de $\mathrm{Si}$} & TE & $-0,20$ & $-0,25$ & $-0,23$ \\
\hline & LR & 0,19 & 0,37 & $0,70^{*}$ \\
\hline \multirow[t]{2}{*}{$\mathrm{Si}$ acumul. $\mathrm{x}$ teor de $\mathrm{Si}$} & TE & 0,26 & $0,69^{*}$ & $0,82^{* *}$ \\
\hline & LR & $0,60^{\circ}$ & $0,88^{* *}$ & $0,98^{* *}$ \\
\hline
\end{tabular}

(1) * $e^{-}$, valores significativos a $5 \%$ e $1 \%$, respectivamente. 
Tabela 29 - Coeficientes de correlação linear entre algumas variáveis relacionadas à parte aérea de plantas de arroz cultivadas em amostras de Terra Roxa Estruturada (TE) e Latossolo Roxo (LR) tratadas com diferentes fontes de fósforo; número de observações igual a 16 (4 repetições $\mathrm{x} 4$ doses) ${ }^{(1)}$

\begin{tabular}{|c|c|c|c|c|}
\hline \multirow{2}{*}{$\begin{array}{l}\text { Variáveis } \\
\text { correlacionadas }\end{array}$} & \multirow[b]{2}{*}{ Solo } & \multicolumn{3}{|c|}{ Fontes de fósforo ${ }^{(2)}$} \\
\hline & & $\mathrm{TM}$ & $\mathrm{ST}+\mathrm{CAL}$ & ST \\
\hline \multirow[t]{2}{*}{ Mat. seca x P acumulado } & $\mathrm{TE}$ & $0,96^{* *}$ & $0,97^{* *}$ & $0,97^{* *}$ \\
\hline & LR & $0,99 * *$ & $0,97^{* *}$ & $0,99^{* *}$ \\
\hline \multirow[t]{2}{*}{ Mat. seca x Si acumulado } & $\mathrm{TE}$ & $0,99^{* *}$ & $0,86^{*}$ & $0,96^{* *}$ \\
\hline & LR & $0,97^{* *}$ & $0,89^{* *}$ & $0,93^{* *}$ \\
\hline \multirow[t]{2}{*}{ Mat. seca $x$ teor de $P$} & TE & $0,93^{* *}$ & $0,93^{* *}$ & $0,95^{* *}$ \\
\hline & LR & $0,86^{* *}$ & $0,59^{*}$ & $0,72^{* *}$ \\
\hline \multirow[t]{2}{*}{ Mat. seca $\mathrm{x}$ teor de $\mathrm{Si}$} & $\mathrm{TE}$ & $-0,96^{* *}$ & $-0,98^{* *}$ & $-0,94^{* *}$ \\
\hline & LR & $-0,83^{* *}$ & $-0,97^{* *}$ & $-0,95^{* *}$ \\
\hline \multirow[t]{2}{*}{ Teor de $\mathrm{P}$ x teor de Si } & TE & $-0,89^{* *}$ & $-0,92^{* *}$ & $-0,90^{* *}$ \\
\hline & LR & $-0,62^{*}$ & $-0,65^{*}$ & $-0,79^{* *}$ \\
\hline \multirow[t]{2}{*}{ P acumul. x Si acumul. } & $\mathrm{TE}$ & $0,95^{* *}$ & $0,74^{* *}$ & $0,90^{* *}$ \\
\hline & LR & $0,96^{* *}$ & $0,80^{* *}$ & $0,91^{* *}$ \\
\hline \multirow[t]{2}{*}{ P acumul. $x$ teor de $S i$} & TE & $-0,92^{* *}$ & $-0,95^{* *}$ & $-0,91^{* *}$ \\
\hline & LR & $-0,80^{* *}$ & $-0,96^{* *}$ & $-0,95^{* *}$ \\
\hline \multirow[t]{2}{*}{ Si acumul. $x$ teor de $\mathrm{Si}$} & TE & $-0,93^{* *}$ & $-0,78^{* *}$ & $-0,84^{* *}$ \\
\hline & LR & $-0,69 *$ & $-0,87^{* *}$ & $-0,88^{* *}$ \\
\hline
\end{tabular}

(1) * $\mathrm{e}^{-}$, valores significativos a $5 \%$ e $1 \%$, respectivamente.

${ }^{2} \mathrm{TM}$, termofosfato magnesiano; ST, superfosfato triplo; $\mathrm{CAL}$, mistura de $\mathrm{CaCO}_{3}$ e $\mathrm{MgCO}_{3}$ na relação 4:1. 
Os coeficientes de correlação entre matéria seca e teor de silício foram elevados, negativos e altamente significativos para ambos os solos e todas as fontes, conseqüência da relação inversa entre essas variáveis, já comentada no item 4.2.2.

Igualmente negativos e altamente significativos foram os coeficientes encontrados entre fósforo acumulado e teor de silício, para ambos os solos e todas as fontes; esse efeito ocorreu porque a quantidade de fósforo acumulada, com o aumento das doses, acompanhou de perto a produção de matéria seca. Pelo mesmo motivo, tanto o teor de fósforo quanto a quantidade de silício acumulada correlacionaram-se negativamente com o teor de silício na planta, embora em menor grau.

Conforme exposto, as correlaçōes negativas confirmam as observações feitas anteriormente sobre os parâmetros da planta. Todas as correlações em que uma das variáveis era produção de matéria seca ou quantidade de fósforo acumulada, e a outra, uma variável que não fosse o teor de silício, foram quase sempre positivas e altamente significativas; a causa disso é que houve forte correlação entre produção de matéria seca e quantidade de fósforo acumulada, confirmando que a participação do fósforo foi maior que a do silício na produção de matéria seca. 


\section{CONCLUSÕES}

a) P método de extração de fósforo pela resina mostrou-se superior ao do Bray-1 em avaliar o efeito das fontes sobre o teor de fósforo no solo, o qual se refletiu inclusive, na produção de matéria seca e na quantidade de fósforo acumulada na parte aérea da planta.

b) $\mathrm{O}$ termofosfato magnesiano elevou o teor de P-resina no solo em maior grau que o superfosfato triplo e de modo semelhante ao superfosfato triplo com corretivo; causou, ainda, aumentos do $\mathrm{pH}$, da saturação por bases e do teor de sílica solúvel do solo.

c) O superfosfato triplo associado ao corretivo provocou ligeiro decréscimo do teor de sílica do solo com o aumento do $\mathrm{pH}$.

d) A aplicação de fósforo, devido ao efeito de diluição, reduziu acentuadamente o teor de silício da planta, mesmo quando a fonte era o termofosfato magnesiano; a aplicação de silício, contudo, não reduziu os teores de fósforo; esses fatos indicam que o $\mathrm{P}$ provavelmente tenha inibido a absorção de $\mathrm{Si}$; mas que o Si não tenha inibido a de $\mathrm{P}$.

e) Todas as fontes de fósforo aumentaram a quantidade de silício acumulada na planta, porém, o termofosfato magnesiano destacou-se das demais.

f) O termofosfato magnesiano foi a fonte que causou o maior aumento no teor de fósforo na planta, seguido do superfosfato triplo associado ao corretivo do $\mathrm{pH}$ e do superfosfato triplo sem corretivo. 
g) O termofosfato magnesiano e o superfosfato triplo associado ao corretivo do solo aumentaram igualmente a produção de matéria seca (nas doses 100 e $200 \mathrm{mg} / \mathrm{kg}$ de P para o solo TE e 50, 100 e $200 \mathrm{mg} / \mathrm{kg}$ de P para o LR) e a quantidade de fósforo acumulada na planta (nas doses 100 e $200 \mathrm{mg} / \mathrm{kg}$ de $P$ para o TE e 50 e $100 \mathrm{mg} / \mathrm{kg}$ de $P$ para o LR), sendo esses aumentos superiores aos obtidos com o superfosfato triplo; assim, o efeito favorável do termofosfato magnesiano sobre $\mathrm{o}$ aproveitamento do fósforo $\mathrm{e} o$ desenvolvimento das plantas se deve mais provavelmente à sua capacidade de elevar o pH do meio do que à influência benéfica da competição entre o silicato que contém e o fosfato, pelos mesmos sítios de adsorção no solo.

h) O termofosfato magnesiano foi superior ao superfosfato triplo, com ou sem corretivo, quanto à produção de matéria seca e a quantidade de fósforo acumulada na planta quando aplicado na dose de $50 \mathrm{mg} / \mathrm{kg}$ de P na Terra Roxa Estruturada; esse comportamento devese, provavelmente, ao efeito combinado da sua ação alcalinizante com o da competição entre o silicato que contém e o fosfato. 


\section{REFERÊNCIAS BIBLIOGRÁFICAS}

ALY, M.Y. Effect of phosphorus, silicon and Zinc applications on the yield and mineral compositions of sugarcane. Honolulu, 1966. 133p. (M.S. - University of Hawai).

ANDO, J. Studies on fused calcium magnesium phosphate fertilizer. Tokyo, Faculty of Engineering, Chu University, 1958. 30 p.

AYRES, A. Calcium silicate slag as a growth stimulant for sugarcane on low-silicon soils. Soil Science, Baltimore, 101:216-7, 1966.

BARBOSA FILHO, M.P. Transformaçōes de fósforo em solos ácidos e sua disponibilidade para a cultura de arroz de sequeiro (Oryza sativa L.). Piracicaba, 1986. 104p. (Doutorado - Escola Superior de Agricultura "Luiz de Queiroz"/USP).

BATAGLIA, O.C.; FURLANI, A.M.C. ; TEIXEIRA, J.P.F.; FURLANI, P.R.; GALLO, J.R. Métodos de análise química de plantas. Campinas, IAC, 1983. 48p. (IAC. Boletim Técnico, 78).

BESSOAIN, E. Mineralogia de arcillas de suelos. San José, Instituto Interamericano de Cooperación para la Agricultura, IICA, 1985. 1216 p. 
BECKWITH, R.S. \& REEVE, R. Studies on soluble silica in soils. Australian Journal Soil Research, East Melbourne, 1:157-68, 1963.

BORKERT, C.M.; CORDEIRO, D.S.; SFREDO, G.J.; PALHANO, J.B.; DITRICH, R.C. Efeito de diversas doses de fósforo de diferentes fosfatos naturais na produção de soja, em condições de primeiro cultivo. In: SEMINÁRIO NACIONAL DE PESQUISA DE SOJA, 1., Londrina, 1978. Anais. Londrina, EMBRAPA/CNPSo, 1979. p.291-8.

BRADY, N.C. Natureza e propriedades dos solos. 7.ed. Rio de Janeiro, Freitas Bastos, 1989. 715p.

BRASIL. MINISTÉRIO DA AGRICULTURA. Comissão de Solos. Levantamento de reconhecimento dos solos do Estado de São Paulo. Rio de Janeiro, 1960. 634p. (Boletim 12).

BRASIL. MINISTÉRIO DA AGRICULTURA. Análise de corretivos, fertilizantes e inoculantes; métodos oficiais. Rio de Janeiro, 1988. 104p.

BRAUN, W.A.G. Relação-solo-planta e termofosfatos. Revista Fertilizantes, 2:3-8, 1980.

BRAY, R.H. \& KURTZ, L.T. Determination of total, organic and available forms of phosphorus in soil. Soil Science, Baltimore, 59 (1):39-45, 1945.

CABALA, R.P. \& FASSBENDER, H.W. Formas del fósforo en suelos de la región cacaotera de Bahia, Brasil. Turrialba, San Jose, 20(4):439-44, 1970.

CAMARGO, O.A. de; MONIZ, A.C.; JORGE, J.A.; VALADARES, J.M.A.S. Métodos de análise química, minerológica e física do solo do Instituto Agronômico de Campinas. Campinas, Instituto Agronômico, 1986. 94p. (IAC. Boletim Técnico, 106). 
CAMARGO, O.A. de; RAIJ, B. van \& GROHMANN, F. Influência de cátions trocáveis e $\mathrm{pH}$ na fixação do fósforo e solos. Ciência e Cultura, Campinas, 28(6):678-81, 1976.

CASTRO, D.M. Mineralogia de suelos. Bogotá, Instituto Geográfico Agustin Codazzi, 1975, v.11, 828p.

CATANI, R.A. \& GALLO, R.J. Avaliação da exigência de calcário dos solos do Estado de São Paulo mediante a correlação entre $\mathrm{pH}$ e a poturação por bases. Revista de Agricultura, Piracicaba, 30:49-60, 1955.

CHANG, S.C. \& JACKSON, M.L. Soil phosphorus fractions in some representative soils. Journal of Soil Science, Oxford, 9:109-19, 1958.

CHIEN, S.H. Reactions of phosphate roks, rhenania phosphate, and superphosphate with and acid soil. Soil Science Society of America Journal, Madison, 42:705-8, 1978.

COMHAIRE, M. The role of silica for plants. Agri Digest, Bruxelas, 7:9-19, 1966.

DEMATTÊ, J.L.I. Curso de gênese e classificação de solos; LSG-418. Piracicaba, ESALQ / Depto. de Solos, Geologia e Fertilizantes, 1987. p.irreg.

EMPRESA BRASILEIRA DE PESQUISA AGROPECUÁRIA, EMBRAPA. Adubação fosfatada no Brasil. Brasília, 1982.

ENGEL, W. Contribution to the function of silica in plant tissues. Naturwissenschaften, Berlin, 45:316-7, 1958.

FASSBENDER, H.W. \& MOLINA, R. Influência de enmiendas calcáreas y silicatadas sobre el efecto de fertilizantes fosfatados en suelos derivados de cenizas volcánicas em Costa Rica. In: Panel sobre Suelos derivados de cenizas volcánicas de América Latina. Turrialba, Costa Rica, IICA, 1969. pp.C.2C.2.12. 
FEITOSA, C.T.; RAJ, B. van; DECHEN, A.R.; ALCARDE, J.C. Determinação preliminar da eficiência relativa de fosfatos, para trigo, em casa de vegetação. Revista Brasileira de Ciência do Solo, Campinas, 2:193-5, 1978.

FURLANI, P.R. \& GALLO, J.R. Determinação de silício em material vegetal pelo método colorimétrico do azul-de-molibdênio. Bragantia, Campinas, (37): V-XI, 1978 (Nota 2).

GOEDERT, W.J. \& LOBATO, E. Eficiência agronômica de fosfatos em solos de cerrado. Pesquisa Agropecuária Brasileira, Brasília, 18(5):499-506, 1983.

GOEDERT, W.J. \& LOBATO, E. Avaliação agronômica de fosfatos em solos de cerrado. Revista Brasileira Ciência do Solo, Campinas, 8:97-102, 1984.

GOEDERT, W.J.; SOUZA, D.M.G.; LOBATO, E. Fósforo. In: . Solos de cerrado; tecnologia e estratégias de manejo. São Paulo, Nobel, 1987. p.129-66.

GOEDERT, W.J.; REIN, T.A.; SOUSA, D.M.G. Eficiência agronômica de fertilizantes fosfatados não tradicionais. In: CONGRESSO NACIONAL DE ROCHA FOSFÁTICA, 3., ENCONTRO NACIONAL DE ROCHA FOSFÁTICA. Brasília, 1986. Brasília, IBRAFOS, 1986. p.415-29.

GRANDE, M.A.; CURI, N.; QUAGGIO, J.A. Disponibilidade de fósforo pelos extratos de Mehlich e resina em solos cultivados com arroz irrigado. Revista Brasileira de Ciência do Solo, Campinas, 10: 45-50, 1986.

GURGEL, M.N.A. Efeitos do silicato de cálcio e sua interação com o fósforo no estado nutricional, produtividade e qualidade tecnológica da cana-de-açúcar (Saccharum sp.). Piracicaba, 1979. 62p. (Mestrado - Escola Superior de Agricultura "Luiz de Queiroz" / USP). 
HINGSTON, F.J.; POSNER, A.M.; QUIRK, J.P. Anion adsorption by goethite and gibsite. The role of the proton in determinning adsorption envelopes. The Journal of Soil Science, Oxford, 23(2):177-92, 1972.

HINGSTON, F.J.; ATKINSON, R.J.; POSNER, A.M.; QUIRK, J.P. Specific adsorption of the anions on goethite. In: INTERNATIONAL CONGRESS OF SOIL SCIENCE, 9., 1968. Proceedings. Soil Science, Baltimore, 1:669-78, 1968.

JONES, L.H.P. \& HANDRECK, K.A. Effects of iron and aluminium oxides on silica in solution in soils. Nature, London, 198:852-3, 1963.

JONES, L.H.P. \& HANDRECK, K.A. Silica in soils, plants and animals. Advances in Agronomy, New York, 19:107-49, 1967.

KABATA-PENDIAS, A. \& PENDIAS, H. Trace and elements in soils and plants. Florida, CRC Press, 1984. 315p.

KAMINSKI, I. Efeitos de cinco fosfatos pré, pró e pós-aplicados ao calcário, no suprimento do fosforo ao sorgo (Sorghum bicolor (L.) c.v. Contibrasil) em três solos ácidos. Piracicaba, 1983. 126p. (Doutorado - Escola Superior de Agricultura "Luiz de Queiroz"/USP).

KAMPRATH, E.J. Phosphorus fixation and availability en highly weathered soils. In: SIMPÓSIO SOBRE O CERRADO, BASES PARA A UTILIZAÇÃO AGROPECUÁRIA, 4., Brasília, 1976. São Paulo, EDUSP, 1977. p.333-47.

KAMPRATH, E.J. \& WATSON, M.E. Conventional soil and tissue tests for assessing the phosphorus status of soils. In: KHASAWNEH, F.E.; SAMPLES, E.C.; KAMPRATH, E.J. The role of phophorus in agriculture. Madison, Americam Society of Agronomy, 1980. p.433-69. 
KHALID, R.A. \& SILVA, J.A. Residual effect of calcium silicate on $\mathrm{pH}$, phosphorus and aluminium in a tropical soil profile. Soil Science and Plant Nutrition, Tokyo, 26(1):87-98, 1980.

KHASAWNEH, F.E. \& DOLL, E.C. The use of phosphate rocks for direct application to soil. Advances in Agronomy, New York, 30:159-206, 1978.

KILMER, V.J. SILICON. In: BLACK, C.A., ed. Methods of soil analysis. Madison, American Society of Agronomy, 1965. p.959-62.

LARSEN, S. Soil phosphorus. Advances in Agronomy, New York, 19:151-209, 1967.

LINDSAY, W.L. Chemical equilibria in soils. New York. John Wiley, 1979. 449 p.

MALAVOLTA, E. Manual de química agrícola; nutrição de plantas e fertilidade do solo. São Paulo, Agronômica Ceres, 1976. 528p.

MALAVOlTA, E. Elementos de nutrição mineral de plantas. São Paulo, Agronômica Ceres, 1980. 251p.

MALAVOLTA, E. Manual de química agrícola; adubos e adubação fosfatada. 3.ed. São Paulo, Ceres, 1981. 596p.

MALAVOLTA, E. Adubos e adubação fosfatada. Piracicaba, Fertilizantes Mitsui S.A., 1985. 61p.

MARSCHNER, H. Mineral nutrition of higher plants. London, Academic Press, 1986. 674p.

McKEAGUE, J.A. \& CLINE, M.G. Sílica in soil solutions. I. The form and concentration of dissolved silica in aqueous extracto of some soils. Canadian Journal of Soil Science, Ottawa, 13:70-82, 1963 . 
McKEAGUE, J.A. \& CLINE, M.G. Sílica in soil solutions. II. The adsorption of monosilicic acid soil and other substances. Canadian Journal of Soil Science, Ottawa, 43:83-96. 1963b.

MELLO, F.A.F.; ARTUR, V.; VICTORIA, R. Efeito de três adubos fosfatados sobre a acidez de um solo hidromórfico. Revista de Agricultura, Piracicaba, 56(4):307-11, 1981.

MÉNDEZ, J.R.B. Efeito das épocas de calagem na disponibilidade de fósforo aplicado 180 dias antes do plantio do arroz, em latossolos sob cerrado. Piracicaba, 1986. 93p. (Mestrado - Escola Superior de Agricultura "Luiz de Queiroz"/USP).

MENGEL, K. \& KIRKBY, E.A. Principles of plant nutrition. 3.ed. Bern, International Potash Institute, 1982. 655p.

MIYAKE, Y. \& TAKAHASHI. Effect of silicon on the growth of cucumber plant in soil culture. Soil Science and Plant Nutrition, Japan, 29(4):463-71, 1983.

MORELLI, J.L.; NELLI, E.J.; BAPTISTELLA, J.R.; DEMATTÊ, J.L.I. Termofosfato na produtividade da cana-de-açúcar e nas propriedades químicas de um solo arenoso de baixa fertilidade. Revista Brasileira de Ciência do Solo, Campinas, 15:57-61, 1991.

MUNK, H. The significance of siliceous materials in fertilizing cultived plants. Soil and Fertilizers, Wallingford, 46(10):1077, 1983.

MURPHY, J. \& RILEY, J.P. A modificied single solution method for the determination of phosphate in natural waters. Analytica Chimica Acta, New York, 27:31-6, 1962. 
MUZILLI, O.; RÍSPOLI, J.C.S.; COSTA, N.A. Efeito da adubação fosfatada em solos ácidos do Sul do Paraná. (Nota Preliminar). Curitiba, UFPR/Escola de Agronomia, 1971. 7p.

OBIHARA, C.H. \& RUSSEL, W. Specific adsorption of silicate and phosphate by soils. The Journal of Soil Science, Oxford, 23(1):105-17, 1972.

OKUDA, A. \& TAKAHASHI. The role of silicon. In: The mineral nutrition of rice plant. Balimore, John Hopkins, 1964. p.124-44.

OLIVEIRA, M.G.A. Determinação, adsorção e deslocamento recíproco de silício e fosfóro em latossolos do Triângulo Mineiro. Viçosa. 1984. 68p. (M.S. Universidade Federal de Viçosa).

PLUCKNETT, D.L. The use soluble silicate in Hawaiian agriculture. University of Queensland Papers, 1(6):203-23, 1972.

QUAGgIO, J.A. Critérios para calagem em solos do Estado de São Paulo. Piracicaba, 1983. 76p. (Mestrado, Escola Superior de Agricultura "Luiz de Queiroz"/USP).

RAIJ, B. van. Seleção de métodos de laboratório para avaliar a disponibilidade de fósforo em solos. Revista Brasileira de Ciência do Solo, Campinas, 2:1-9, 1978.

RAIJ, B. van. Avaliação da fertilidade do solo. Piracicaba, Instituto da Potassa e Fosfato, 1981. cap.7, p.95-106.

RAIJ, B. van. Fertilidade do solo e adubação. São Paulo, Agronômica Ceres, 1991. $343 \mathrm{p}$. 
RAIJ, B. van \& CAMARGO, O.A. de. Sílica solúvel em solos. Bragantia. Campinas, 32(11):223-35, 1973.

RAIJ, B. van. \& QUAGGIO, J.A. Métodos de análise de solo para fins de fertilidade. Campinas, Instituto Agronômico, 1983. 31 p. (IAC. Boletim Técnico, 81).

RAIJ, B. van; FEITOSA, C.T.; CARMELLO. Q.A.C. A adubação fosfatada no Estado de São Paulo. In: OLIVEIRA, A.J.; LOURENÇO, S.; GOEDERT, W.J. ed. Adubação fosfatada no Brasil. Brasília, EMBRAPA/DID, 1982. p.103-36.

RAJAN, S.S.S. Phosphate adsorption and the displacement of structural silicon in an allophane day. Journal of Soil Science, Baltimore, 26:250-6, 1975.

RESENDE, M. \& SANTANA, D.P. Uso das relações Ki e $\mathrm{Kr}$ na estimativa da mineralogia para classificação dos latossolos In: REUNIÃO DE CLASSIFICAÇÃO, CORRELAÇÃO DE SOLOS E INTERPRETAÇÃO DE APTIDÃo AGRÍCOLA, 3., Rio de Janeiro, 1988. Anais. Rio de Janeiro. EMBRAPA/SNLCS, 1988. p.255-32. (EMBRAPA. Documentos SNLCS, 12).

ROCHA, R.B. Comparação entre fontes de fósforo através de três extratores químicos do solo e plantas de arroz. Piracicaba, 1994. 75p. (Mestrado Escola Superior de Agricultura "Luiz de Queiroz"/USP).

ROTHBUHR, \& SCOTT, F. A study of the uptake of silicon and phosphorus by wheat plants with radio chemical methods. Biochemie Journal, London, 65;241-5, 1957.

ROY, A.C.; ALI, M.Y.; FOX, R.L. \& SILVA, J.A. Influence of calcium silicate on phosphate solubility and availability in Hawaian Latosols. In: SYMPOSIUM ON SOIL FERTILITY E EVAlUATION, Honolulu, 1971. Proceedings, New Delhi, 1971. p.756-65. 
SANTOS, P.S. Tecnologia das argilas aplicada às argilas brasileiras. São Paulo, USP, 1975. 2v.

SARRUGE, J.R. \& HAAG, H.P. Análises químicas de plantas. Piracicaba, ESALQ, 1974. 57p.

SCARSETH, G.D. The mechanism of phosphate retention by natural alumino silicate colloids. Journal American Society, Washington, 27:596-616, 1965.

SEATZ, L.F.; TIDALE, S.L.; WINTERS, E. Crop response to fused tricalcium hosphate. Agronomy Journal, Madison, 46:574-9, 1954.

SHERMAN, G.D. Crop growth response applications of calcium silicate to tropical soil in Hawaian Islands. Agriculttural Digest, Coventry, 18:11-9, 1969.

SILVA, J.A. Possible mechanisms for crop response to silicate applications. Proceedings of International Symposium Soil Fert. Evaluation, 1:805-14, 1971.

SMYTH, T.J. Comparison of the effects of phosphorus, lime and silicate application of phosphorus sorption in exchange and rice growth in an oxisol from the cerrado of Brasil. Raleigh, 1976. 138p. (Ph.D. - North Carolina State University).

SMYTH, T.J. \& SANCHEZ, P.A. Effects of lime, silicate and phosphorus applications to an oxisol on phosphorus sorptions and ion retention. Soil Science Society of Amererican Journal, Madison, 44:500-5, 1980.

TISDALE, S.L.; NELSON, W.L. \& BEATON, J.D. Soil fertility and fertilizers. 4.ed. New York, Macmillan, 1985. 754p. 
THENG, B.K.G. Soils with variable charge. Palmerston North, New Zealand Society of Soil Science, 1980. 448p.

THOMAS, G.W. \& PEASLEE, D.E. Testing soil for phosphorus. In: WALSH, L.W. \& BEATON, J.D., ed. Soil testing and plant analysis. Madison, SSSA, 1973. p.15-29.

VETTORI, L. Métodos de análise de solo. Rio de Janeiro, Ministério da Agricultura, 1969. 24p. (Boletim Técnico, 7).

VITTI, G.C. Avaliação e interpretação do enxofre no solo e na planta. Jaboticabal, UNESP/FUNEP, 1989. 37p.

VOLKWEISS, S.J. \& RAIJ, B. van. Retenção e disponibilidade de fósforo em solos. In: SIMPÓSIO SOBRE CERRADO: BASES PARA UTILIZAÇÃO AGROPECUÁRIA, 4., Brasília, 1976. São Paulo, EDUSP, 1977. p.317-32.

WERNER, D. \& ROTH, R. Silica metabolism. In: PIRSON, A. \& ZIMMERMANN, M.H., ed. Inorganic plant nutrition. Spring-Verlag, 1983. 870p. (Encyclopedia of Plant Physiology, 15B).

YASUDA, M. Comportamento de fosfatos silicatados em solos de cerrado. Piracicaba, 1989. 87p. (Mestrado - Escola Superior de Agricultura "Luiz de Queiroz"/USP). 
$-86-$

APÊNDICE 


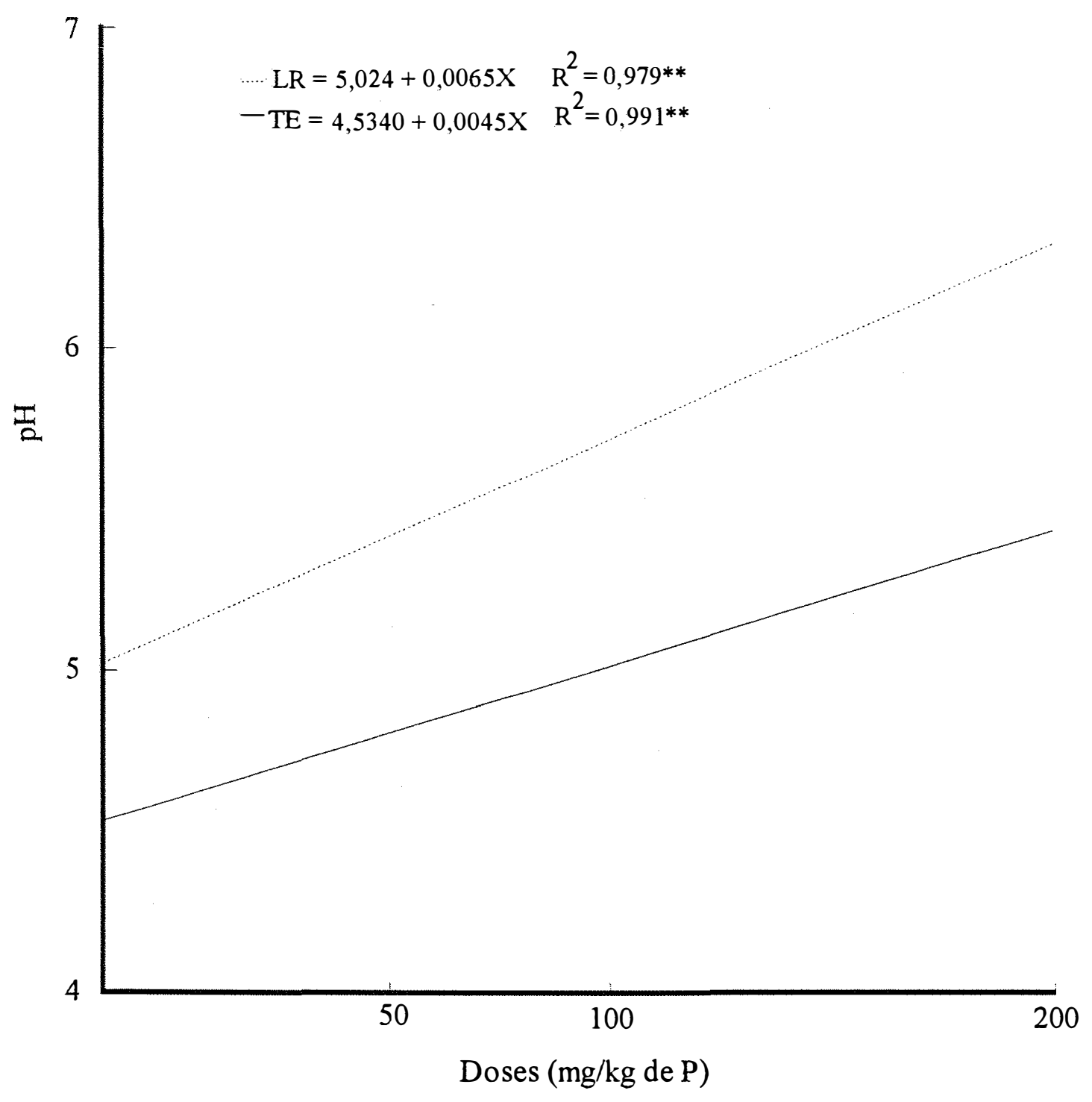

Apendice 1. Curvas de neutralização de duas amostras de solos, após 18 dias de incubação com termofosfato magnesiano, para Terra Roxa Estruturada (TE) e Latossolo Roxo (LR). 


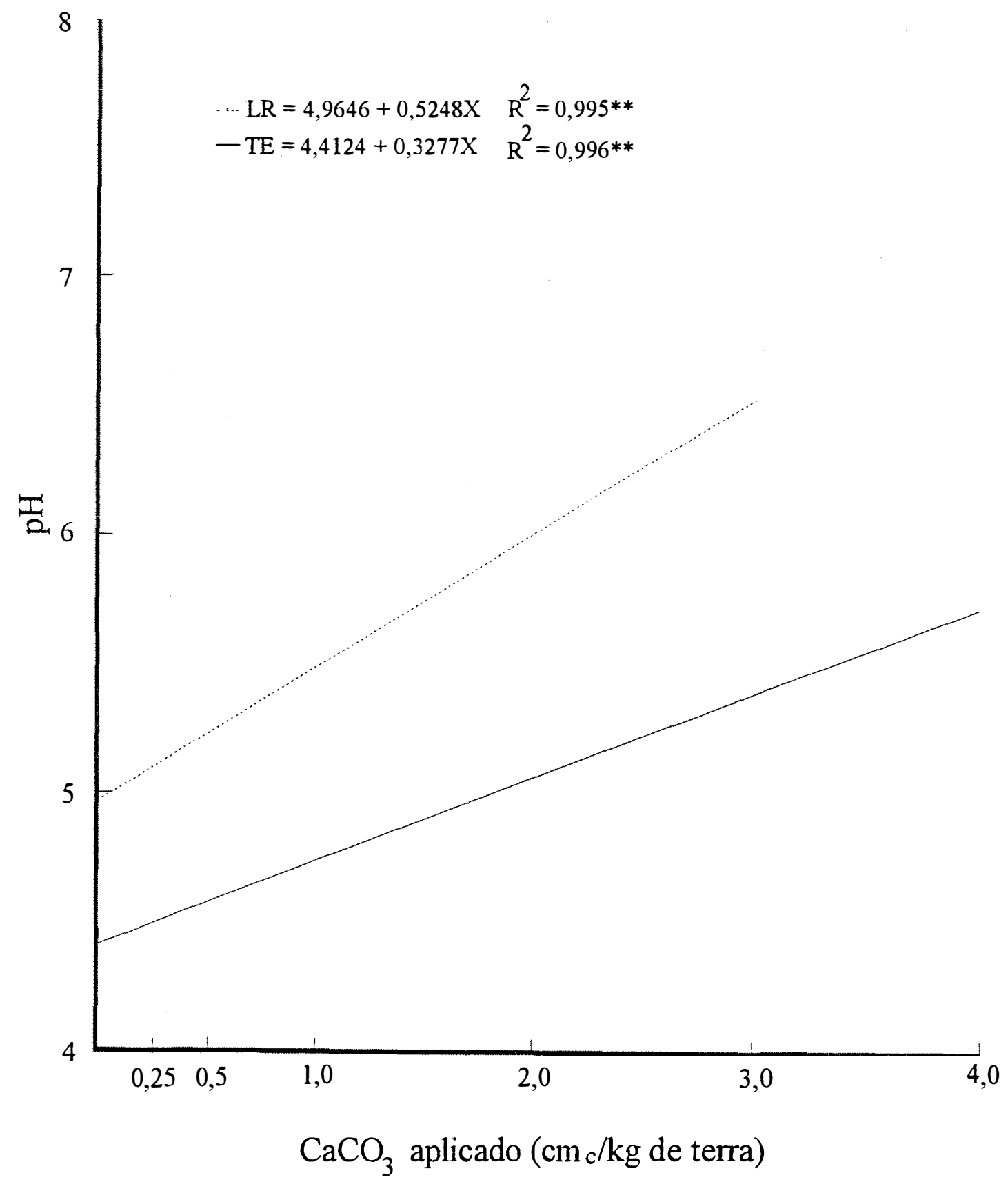

Apêndice 2. Curvas de neutralização de duas amostras de solos, após 18 dias de incubação com $\mathrm{CaCO}_{3}$, para Terra Roxa Estruturada (TE) e Latossolo Roxo (LR). 